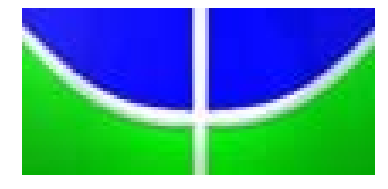

Universidade de Brasília

CET - Centro de Excelência em Turismo

Pós-graduação Lato Sensu

Curso de Especialização em Formação de Consultores em Turismo

\title{
O USO DO TURISMO COMO FERRAMENTA DE DESENVOLVIMENTO DO MUNICÍPIO DE FORMOSA - GO
}

CAROLINA QUEIROZ BORGES

Brasília - DF

Maio/2008 


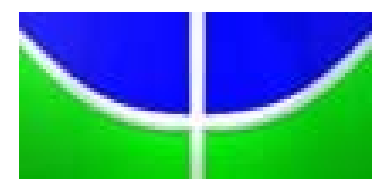

Universidade de Brasília

CET - Centro de Excelência em Turismo

Pós-graduação Lato Sensu

Curso de Especialização em Formação de Consultores em Turismo

\section{O USO DO TURISMO COMO FERRAMENTA DE DESENVOLVIMENTO DO MUNICÍPIO DE FORMOSA - GO}

\section{CAROLINA QUEIROZ BORGES}

Prof ${ }^{a}$. Dra . lara Lúcia Gomes Brasileiro

"Trabalho apresentado ao Centro de Excelência em Turismo da Universidade de Brasília - CET-UnB, como requisito inicial à obtenção do Grau de Especialista em Consultoria em Turismo" 
Borges, Carolina Queiroz.

O uso do turismo como ferramenta para o desenvolvimento do Turismo no município de Formosa /Carolina Queiroz Borges. - Brasília, 2008.

$x, 79 f$. : il. Color; $29 \mathrm{~cm}$

Monografia (especialização) - Universidade de Brasília, Centro de Excelência em Turismo, 2008.

Orientador: $\mathrm{Dr}^{\mathrm{a}}$ lara Brasileiro.

1. Turismo. 2. Desenvolvimento. 3. Sustentabilidade. I. TITULO 


\author{
Universidade de Brasília \\ CET - Centro de Excelência em Turismo
}

Pós-graduação Lato Sensu

Formação de Consultores em Turismo

\title{
O USO DO TURISMO COMO FERRAMENTA DE DESENVOLVIMENTO DO MUNICÍPIO DE FORMOSA - GO
}

\section{CAROLINA QUEIROZ BORGES}

Aprovado por:

\author{
Professor orientador: Dra . Iara Lúcia Gomes Brasileiro \\ Professor Avaliador: Msc Rosana Pinheiro Rezende \\ Professor Avaliador: Msc Luis Henrique de Souza
}

Brasília, 07 de Maio de 2008. 


\section{DEDICATÓRIA}

Dedico este trabalho principalmente aos meus pais $e$ irmãos que me deram todo o apoio que eu precisei nessa trajetória. Aos amigos que estiveram ao meu lado me incentivando a não desistir nos momentos mais tensos do caminho, viajando comigo a Formosa e ajudando nas pesquisas e entrevistas. 


\section{AGRADECIMENTOS}

Agradeço a todos que fizeram parte de todo processo de aprendizagem e de formulação deste projeto. Aos agentes do governo do estado de Formosa, em especial ao senhor Wilmar Aloísio, secretário de Desenvolvimento Econômico, que me deu toda a ajuda e suporte que precisei quando estava na cidade de Formosa, me encaminhou aos demais representantes para que pudesse executar as entrevistas e pesquisas necessárias. Ao senhor Netinho, que teve toda a paciência para me levar aos locais onde faria as pesquisas e entrevista e aos demais que me receberam prontamente para responder as pesquisas. Agradeço a paciência da minha orientadora que apesar da minha insistência em algumas questões e as adversidades que ocorreram no processo, me apoiou e ajudou muito. E aos demais que de uma forma ou de outra estiveram presentes no percurso até aqui; a entrega deste projeto que é uma realização para mim, Muito obrigada. 
EPÍGRAFE

“Uma nova forma de civilização, fundamentada no aproveitamento sustentável dos recursos renováveis, não é apenas possível, mas essencial".

M.S Swaminathan

Pensador indiano 


\section{RESUMO}

Este projeto teve por finalidade a criação de propostas para o desenvolvimento do turismo na cidade e no município de Formosa. Isso porque estes apresentam grande número de atrativos naturais e culturais, que poderiam ser melhor explorados, alcançando o mercado turístico sob forma de produto. Para chegar a esse desenvolvimento fez-se necessário a utilização de dois procedimentos básicos: um diagnóstico e um prognóstico. A elaboração do diagnóstico conta com um olhar sobre o turismo na localidade, no ponto de vista da sociedade, dos representantes do governo local e dos proprietários das terras onde estão tais atrativos naturais. Isto foi feito por meio de pesquisas quantitativas descritivas, além de entrevistas padronizadas e da visão crítica da autora deste projeto. Já a criação do prognóstico traz em seu conteúdo propostas para o incremento da atividade turística, bem como melhor trabalhar os pontos fracos e negativos encontrados e relatados, trazendo idéias como: roteiros integrados, divulgação dos atrativos por meio de um mix de marketing, qualificação e capacitação da mão de obra local e busca de parcerias, dentre outros. Todo o desenvolvimento do projeto foi feito com o intuito de aumentar a quantidade de turistas na região, por meio dos ideais da sustentabilidade, fazendo com que os impactos econômico, social e ambiental sejam os mínimos possíveis.

Palavras-chave: Turismo; Desenvolvimento; Sustentabilidade. 


\begin{abstract}
The goal of this project was to come up with propositions for the development of tourism in the city and region of Formosa, state of Goiás. The reason is that they present a great number of natural and cultural attractions in the area, that could receive a better use in order to reach the touristic market as product. To get to this stage of development it's necessary to follow two basic procedures: to elaborate a diagnosis and a prognosis. The diagnosis consists of a look on the tourism in the site, with points of view from the society, local government representatives and the land owners where the attractions are located. It was done by descriptive quantitative research and padronized interviews, besides the critical approach of this author's project. On the other side, the creation of the prognosis brings in its content suggestions for the increment of the tourist activity, as well as management guidelines to improve the negative and weak aspects found and reported, bringing ideas like integrated routs, advertising of the attractive through a marketing mix, qualify and capacitate local workforce and seek partnerships, among others. The complete development of this project has as its purpose to increase the number of tourists in the region, by means of sustainable ideals, making the economical, social and environmental impacts to be minimized as much as possible.
\end{abstract}

Key words: tourism; development; sustainability. 
SUMÁRIO

INTRODUÇÃO

I - CONCEITUAÇÃO E CARACTERIZAÇÃO DO TURISMO

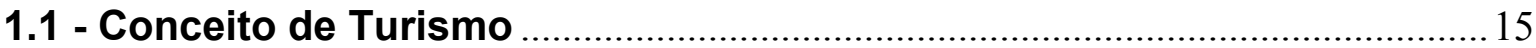

1.3 - Turismo como Atividade Econômica ................................................................. 17

1.3.1 Turismo como Atividade Econômica Brasileira................................................... 17

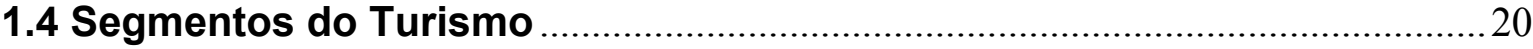

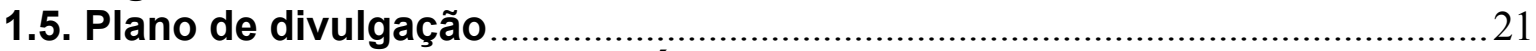

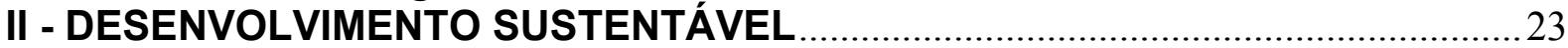

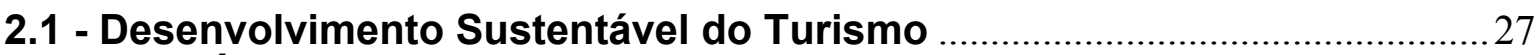

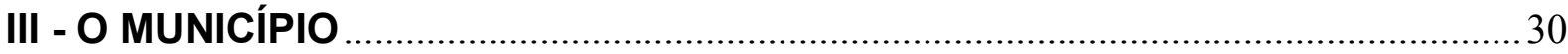

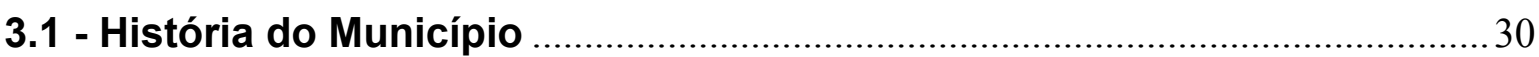

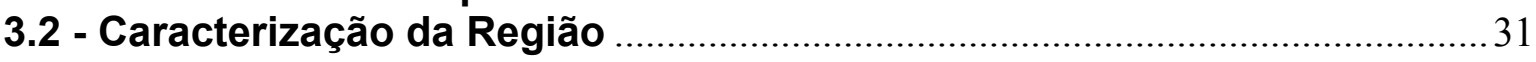

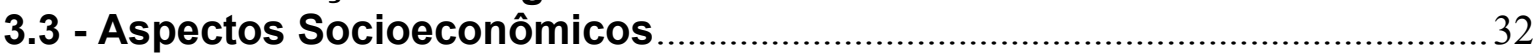

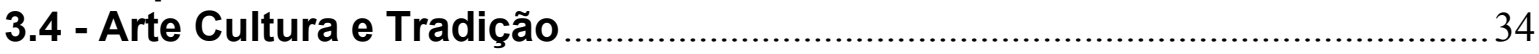

3.5 - Atrativos e Potenciais Naturais e Ecológicos ...............................................36

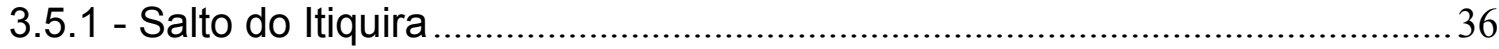

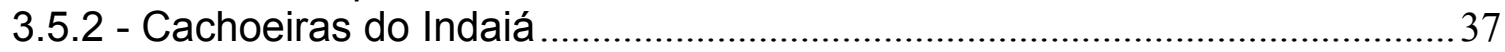

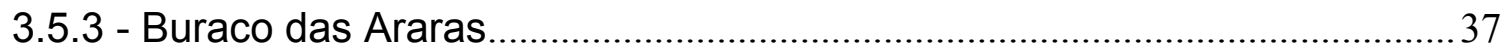

3.5.4 - Gruta das Andorinhas .................................................................................

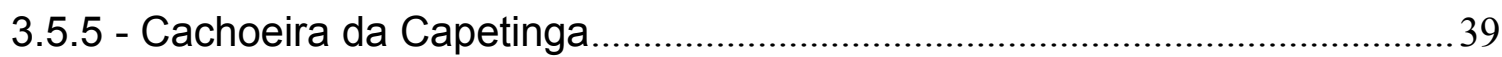

3.5.6 - Cachoeiras do Bandeirinha ........................................................................ 40

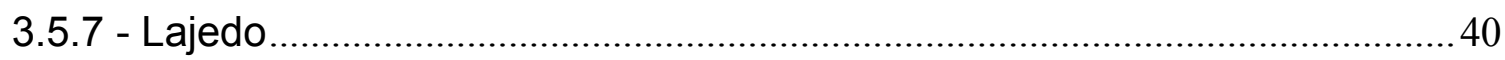

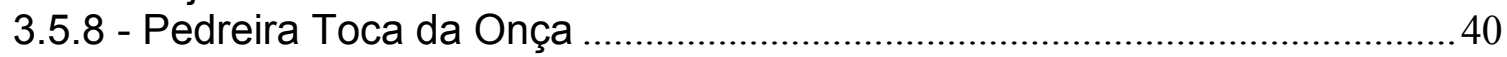

3.5.9 - Sítios Arqueológicos ................................................................................... 41

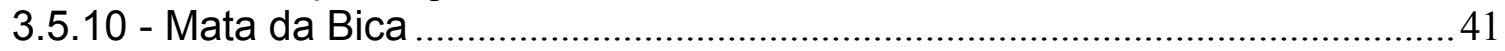

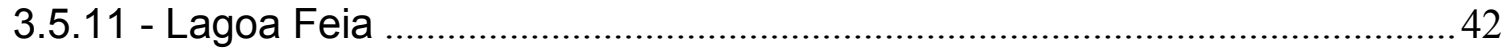

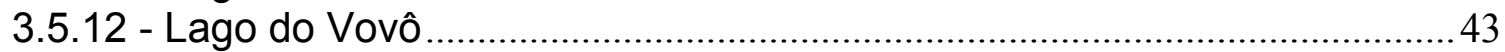

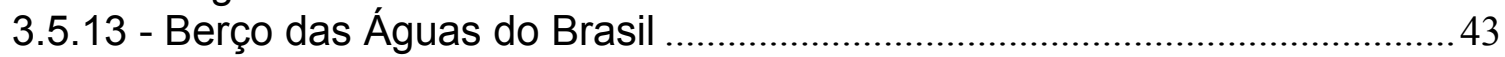

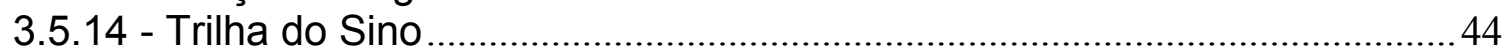

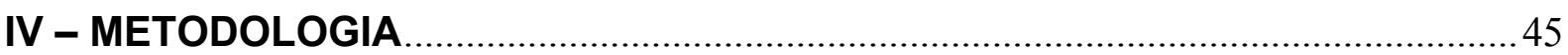

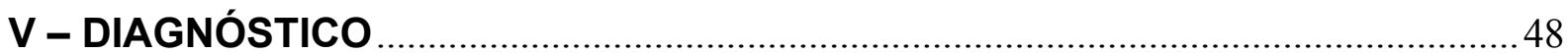

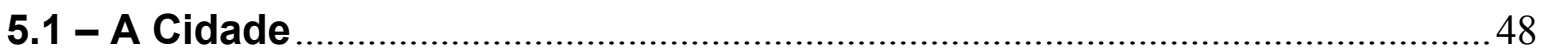

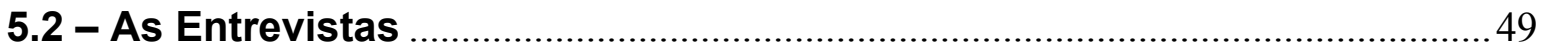

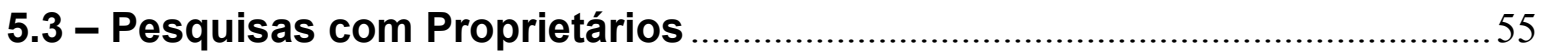

5.4 - Pesquisa com Coordenadores dos Programas Sociais ............................56

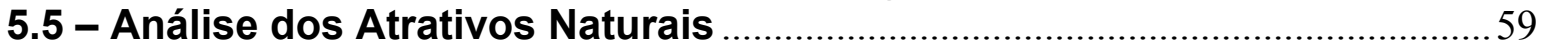

5.6 - Análise SWOT das Potencialidades Turísticas ..........................................59

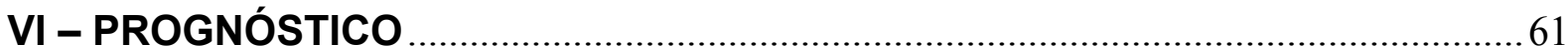

6.1 - Melhorias na Infra-estrutura Básica e dos Atrativos Naturais ....................61

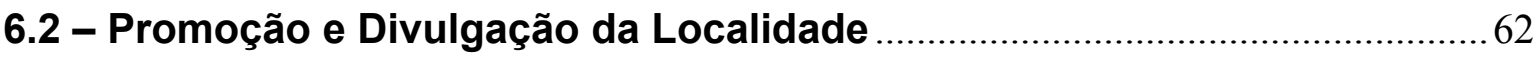

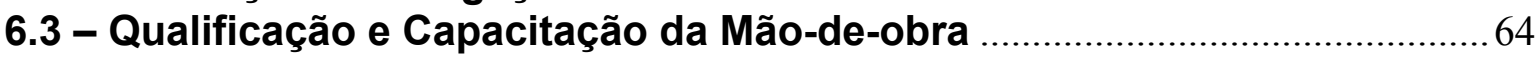

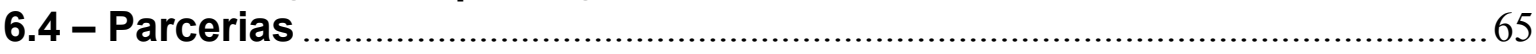

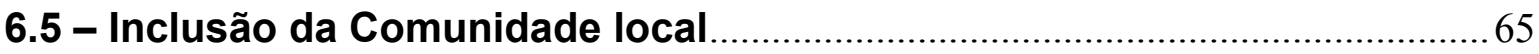

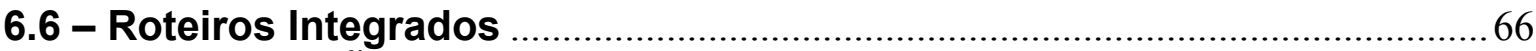

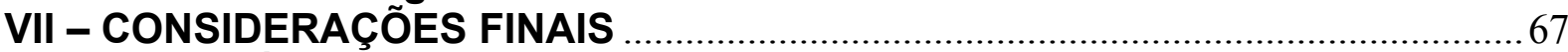

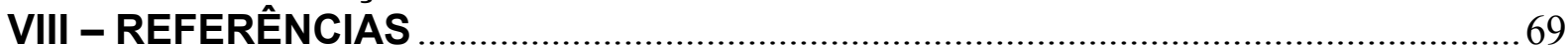




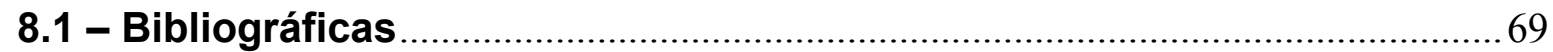

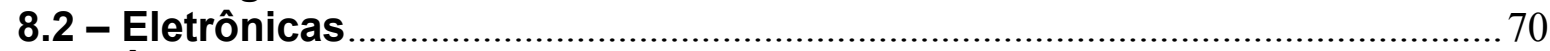

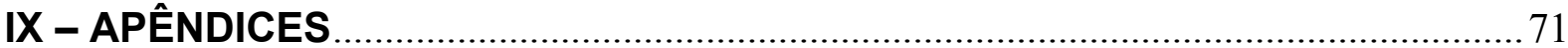

A - Pesquisas com Proprietários dos Atrativos ................................................ 71

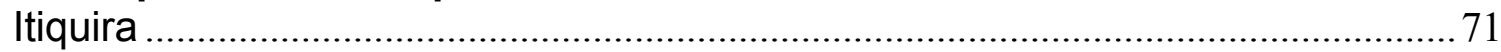

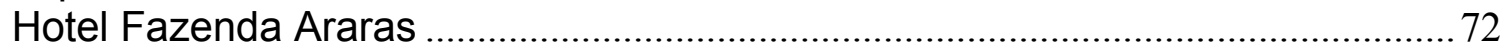

B - Modelo da Pesquisa com os Representantes da Comunidade .................. 73

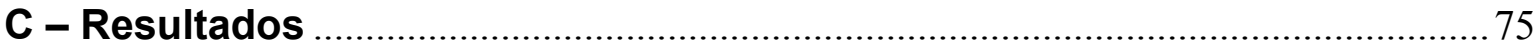

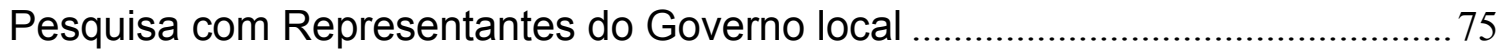

Pesquisa com coordenadores dos programas sociais ......................................... 76

D - Roteiro para entrevista com os secretários de Desenvolvimento

Econômico e de Cultura e Turismo. ............................................................................ 77

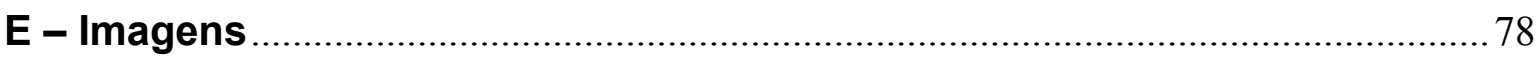

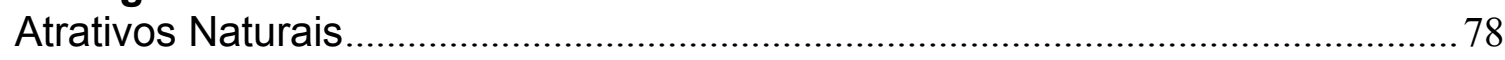

Atrativos Culturais e Infra-Estrutura............................................................ 83 


\section{LISTA DE IMAGENS}

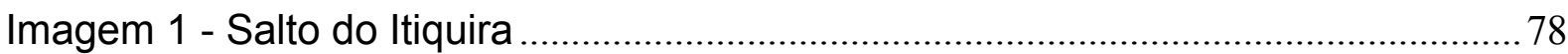

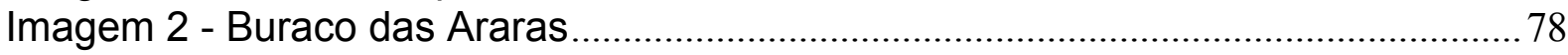

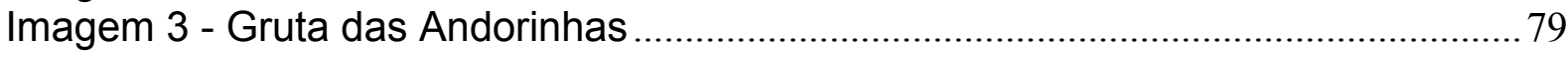

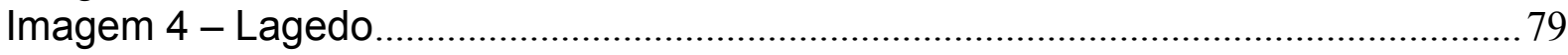

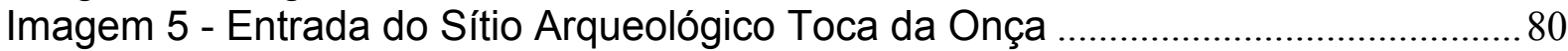

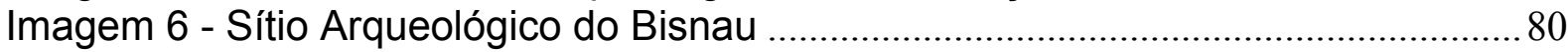

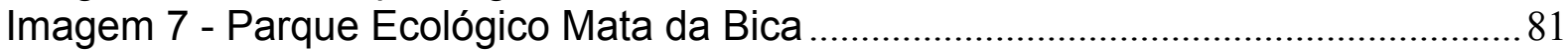

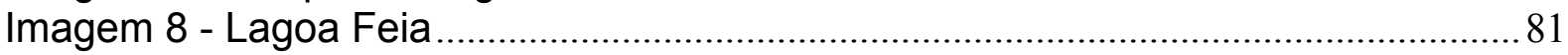

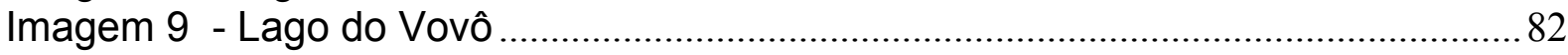

Imagem 10 - Nascente de um dos afluentes da Bacia do São Francisco.................... 82

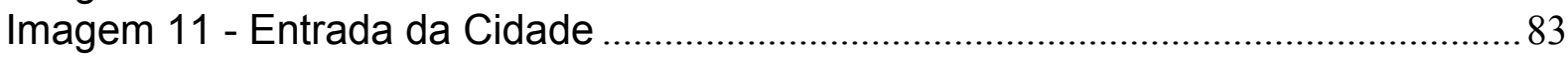

Imagem 12 - Centro de Atendimento ao Turista............................................................ 83

Imagem 13 - Interior do Centro de Cultura Tradição e Turismo de Formosa ...............84

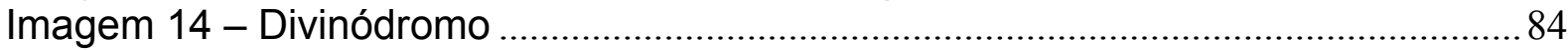

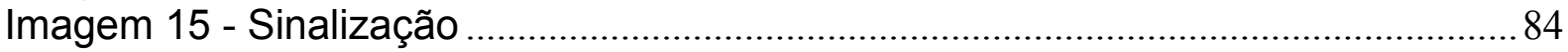




\section{INTRODUÇÃO}

Formosa é um município que apresenta um grande potencial turístico, um grande número de atrativos naturais e culturais, que poderiam ser melhor explorados, alcançando o mercado turístico sob forma de produto ao planejar a infra-estrutura para o desenvolvimento do turismo, fazendo com que represente uma fatia maior da economia local.

O turismo só não se desenvolve no local por falta de conhecimento dos proprietários quanto ao imenso potencial dos atrativos que estão em suas terras e, principalmente por falta de interesse dos órgãos governamentais locais e da inexistência de um plano de desenvolvimento turístico para a localidade.

O principal objetivo foi desenvolver um trabalho que pudesse mostrar aos principais interessados, proprietários e governo, que o turismo pode ser desenvolvido na localidade com base na sustentabilidade, atraindo um grande número de turistas, fazendo com que suas divisas aumentem, podendo tornar os negócios da região mais prósperos.

Para isso foram levantados dados do município e da população por meio de pesquisas e questionários, que a partir de uma tabulação se tornaram a base para proposições de maximização das potencialidades turísticas e desenvolvimento sustentável da região.

Este trabalho conta com uma introdução, conceituação sobre turismo, um histórico do município e dos principais atrativos, caracterizando as formações destes atrativos, a metodologia aplicada para a elaboração e uma tabulação dos dados que foram levantados por meio de questionários.

E ao final apresenta um diagnóstico sobre os dados levantados e por fim um prognóstico, com propostas de cursos de qualificação da mão de obra, meios para divulgar melhor os atrativos e a região, como também a melhor maneira para a divulgação da localidade sem o desgaste de sua imagem. Esse prognóstico buscará como resultado o aumento do fluxo de turistas na localidade.

Formosa é um município com um grande potencial turístico e por meio de um plano de desenvolvimento sustentável para a região, Formosa pode se tornar um dos maiores pólos do Goiás a receber turistas. 
O desenvolvimento sustentável tornou-se ponto fundamental na discussão de qualquer assunto que envolva o meio ambiente, economia e sociedade e sendo o turismo uma atividade que engloba todos esses setores, para poder se desenvolver bem, nada mais certo do que promover a sustentabilidade em qualquer projeto deste setor que hoje gera milhões de empregos diretos e indiretos no mundo inteiro.

Este tema foi escolhido como base para o projeto, pois quando se pensa em transformar uma localidade em região turística, não se pode mais promover esse fenômeno provocando a degradação do meio ambiente local. Por ser da natureza desta atividade a utilização direta dos recursos naturais, e estes por sua vez escassos e esgotáveis, se não utilizados da maneira mais correta um dia acabarão e junto com esses recursos o turismo não mais terá o sustento para que a atividade aconteça.

Atualmente o município apresenta uma carência em sua infra-estrutura urbana e principalmente na oferta de emprego e esse fato acontece por ter a maior parte de sua economia no setor primário o que faz com que sua população procure emprego no Distrito Federal e outras localidades. Mas nos finais de semana a situação é totalmente inversa, população e visitantes do Distrito federal e de outros locais deslocam-se ao município buscando turismo e lazer em locais como: Complexo Turístico do Itiquira, Buraco das Araras, Gruta das Andorinhas, Lagoa Feia entre outros.

Mas apesar de atrair visitantes, observa-se que o turismo na localidade ainda não atingiu seu melhor momento. Como dito anteriormente, Formosa possui muitos atrativos naturais, locais de beleza incomum, mas que ainda não são bem explorados. Muitos desses atrativos estão localizados em propriedades particulares (fazendas), onde muitos dos proprietários ainda não têm a menor idéia do potencial destes atrativos. De acordo com visita realizada e conversa com alguns desses proprietários, constatou-se que eles possuem certo interesse, mas esperam uma iniciativa por parte do governo.

A principal motivação para desenvolver esse estudo é a oportunidade de apresentar um projeto para a prefeitura de Formosa, onde o turismo seja visto como ferramenta para o desenvolvimento local. Tudo isso será feito por meio de uma proposta que trará alternativas para um desenvolvimento sustentável, que será apresentada ao 
Centro de Excelência em Turismo - CET, podendo fazer parte de uma parceria que já existe entre BRASILIATUR e CET/UnB.

A justificativa para a elaboração desse projeto se dá pelo amplo potencial turístico da cidade de Formosa - GO que conta com várias cachoeiras, várias praças, um museu, uma lagoa, uma reserva florestal, sítios arqueológicos dentre outros. Apesar desta variedade de atrativos o turismo em Formosa ainda não atingiu o nível de exploração que traga retornos e benefícios à população, merecendo um maior investimento em planejamento e na definição de prioridades visando o fomento do turismo e um melhor aproveitamento de seus potenciais. Além de buscar melhorar a mão de obra local, que atualmente encontra-se precária, fazendo com que nem sempre o cliente tenha um bom atendimento.

A principal questão a ser respondida é: existe em Formosa um bom nível de preparo dos empreendedores, governo e comunidade local para receber os turistas que procuram por seus atrativos? E assim, em cima dessa questão, implementar junto aos interessados um plano de desenvolvimento para o turismo na região

Este trabalho apresenta como objetivo geral, o aumento do fluxo de turistas no município de Formosa - GO, por meio dos ideais da sustentabilidade. Já como objetivos específicos, serão propostos:

- Avaliar de maneira geral os atrativos naturais e culturais, bem como suas infra-estruturas;

- Propor melhorias necessárias às infra-estruturas dos atrativos dentro da visão do desenvolvimento sustentável do turismo;

- Propor a implementação de cursos de capacitação junto aos órgãos governamentais e proprietários das fazendas onde estão alguns atrativos.

Para que o trabalho pudesse ser realizado fez-se necessária utilização das seguintes metodologias: pesquisas bibliográficas de autores nas áreas trabalhadas no decorrer dos capítulos apresentados, como também pesquisas de campo onde foram realizadas cinco visitas técnicas.

Duas dessas visitas foram feitas aos atrativos para conhecê-los melhor e para a aplicação do questionário aos proprietários. Essa pesquisa conta com questões de origem quantitativa e qualitativa, com o intuito de mensurar dados que remetem ao 
atrativo em questão ${ }^{1}$. Do ponto de vista quantitativo buscou-se informações a respeito do número de empregados existentes e quantos eram da região. Já na parte qualitativa a idéia foi entender como o proprietário trabalha o turismo, a questão da sustentabilidade e a qualificação e capacitação da mão-de-obra. Este questionário é composto por perguntas abertas, fechadas e de múltipla escolha, caracterizando-se em uma pesquisa descritiva também.

As outras três visitas foram na cidade de Formosa, onde foram coletados dados da cidade e realizadas algumas pesquisas e entrevistas com representantes do governo local e da comunidade. As pesquisas contêm questões que procuraram saber desses representantes fatores de caráter quantitativo, visões de como o turismo pode ser trabalhado e divulgado, o que pode ser considerado ganho com o turismo, atitudes que precisam ser tomadas para o uso do turismo como ferramenta para o seu desenvolvimento ${ }^{2}$. Sendo assim caracteriza-se em uma pesquisa qualitativa de caráter descritivo.

A amostra trabalhada foi de caráter acidental e casual estratificada. Quanto aos representantes do governo a intenção inicial era fazer a entrevista estruturada com todos, mas no decorrer do trabalho o que ocorreu foi que nem todos estavam à disposição. Com isso apenas três gestores foram contatados, sendo eles os principais representantes para o turismo neste trabalho que visa o uso dos ideais da sustentabilidade.

Quanto às pesquisas com os representantes da comunidade, foi determinado um número especifico para compor a amostra, sendo ele representado pelos coordenadores dos programas e projetos desenvolvidos pela secretaria de Trabalho e Promoção Social ${ }^{3}$.

Como o intuito do trabalho foi atribuir valor aos dados captados por meio das pesquisas, essa se caracteriza em uma avaliação formativa do Município como um todo, dando origem ao capitulo $V$, que é um diagnóstico da situação da cidade, do município, de como as pessoas desejam que o turismo aconteça, o que fazem ou acham que deve ser feito para que o turismo na região possa se desenvolver.

\footnotetext{
${ }^{1}$ Essas perguntas encontram-se no apêndice A do trabalho.

${ }^{2}$ Essas perguntas encontram-se no apêndice B e D do trabalho.

${ }^{3}$ Essas perguntas encontram-se no apêndice B do trabalho.
} 


\section{I - CONCEITUAÇÃO E CARACTERIZAÇÃO DO TURISMO}

O turismo é definido de diversas maneiras. Atualmente, a literatura voltada para o Turismo o conceitua de forma vasta. Por tratarem do mesmo tema, todos têm vários pontos em comum. Este projeto trará algumas destas conceituações, dando ênfase nas que tem maior aceitação acadêmica.

\section{1 - Conceito de Turismo}

Segundo a Organização Mundial do Turismo (OMT-1994), "o turismo compreende as atividades realizadas pelas pessoas durante suas viagens e estadas em lugares diferentes do seu entorno habitual, por um período consecutivo inferior a um ano, por lazer, negócios ou outros". (SANCHO, 2001, p.03.)

Para muitos autores essa conceituação é a mais válida, sendo assim muito utilizada nos artigos e projetos da área de turismo. Mas como foi dito no início do capítulo, este trabalho abordará as conceituações mais aceitas na área.

Lage e Milone (2001) trazem em seu livro o conceito de turismo dos autores Mathieson e Wall, que mostram o turismo como um fenômeno amplo e por isso deve ser observado por meio de três enfoques:

O movimento temporário de pessoas para locais de destinos
externos a seus lugares de trabalho e moradia; as atividades
exercidas durante a permanência desses viajantes nos locais de
destino, incluindo os negócios realizados; e as facilidades, os
equipamentos e os serviços criados, decorrentes das necessidades
dos viajantes. Já para Jafar Jafari o turismo "é o estudo do homem longe de seu local de residência, da indústria que satisfaz suas necessidades, e dos impactos que ambos, ele e a indústria, geram sobre os ambientes físico, econômico e sócio cultural da área receptora (JAFARI, Apud BENI, 1998, p 36)".

Este conceito aborda o turismo no seu caráter mais sistêmico, revelando o quanto é complexo e amplo, mas principalmente dependente de vários setores que compõem o sistema geral. 


\section{2 - O Processo do Planejamento Turístico}

Para Beni (1998) planejamento é o processo de interferir e programar os fundamentos definidos do turismo que, conceitualmente, abrange três pontos essenciais e distintos: estabelecimento de objetivos; definição de cursos e ação e determinação da realimentação, já que a atividade apresenta enorme interdependência e interação de seus componentes.

De acordo com Petrocchi (1998) a base para qualquer projeto turístico está no desenvolvimento de um bom planejamento, na construção de um plano de desenvolvimento de áreas turísticas. Esses planos devem alcançar a idéia de Turismo Sustentável, e isso só poderá acontecer se houver um gerenciamento, um desenvolvimento minucioso de um setor turístico.

Sendo assim, para Petrocchi (1998) planejamento "é a definição de um futuro desejado e de todas as providencias necessárias à sua materialização". (PETROCCHI, 1998, pág 19.)

E ainda diz que o setor turístico se destaca em dois tipos de planejamento: o modelo mediterrâneo e o modelo americano. No modelo mediterrâneo que surgiu na Europa, permite que o turista se integre com o local que está visitando, trazendo a convivência entre população autóctone e visitante. É um turismo onde se releva mais o âmbito cultural de uma viagem.

Já o modelo americano, também conhecido como sistema fechado, o turista chega à localidade e se depara com uma infra-estrutura de meios de hospedagem, equipamentos turísticos, onde sua visita ao local se resume em se hospedar em um belo hotel que oferece tudo, sem a necessidade de interagir com a comunidade local.

De acordo com Ansarah (2001) todo tipo de planejamento procura estabelecer condições favoráveis para alcançar objetivos propostos para o futuro. Assim graças ao planejamento e suas ferramentas pode-se decidir antecipadamente o que deve ser feito. Essas ferramentas estão em uma linha de ação preestabelecida.

Segundo Molina (2002), planejar é a identificação de uma série de variáveis com o objetivo de obter rumos nas ações, baseadas em análises que permitam alcançar os 
objetivos e as metas. Planejar é prever rumos com um processo contínuo de tomadas de decisões coerentes

\section{3 - Turismo como Atividade Econômica}

De acordo com o que foi ressaltado anteriormente, uma das vertentes da sustentabilidade é o crescimento econômico, onde certa atividade está sendo desenvolvida. Assim essa parte do trabalho abordará conceitos do turismo como atividade econômica, bem como uma idéia de como este setor se apresenta no Brasil.

Na visão de Vaz (2002) o turismo é considerado como uma atividade econômica que mobiliza inúmeros setores produtivos de bens ou serviços, requerendo para isso o trabalho de inúmeras categorias profissionais (VAZ, Apud DE ROSE, 2002, p. 02.)

Este conceito aborda o turismo essencialmente como uma atividade econômica, apresentada como um mecanismo de exportação de renda da localidade emissora para o destino, onde há movimentação de divisas, criação de empregos, aumento na arrecadação de impostos dentre outras movimentações. Os turistas em suas viagens não se limitam ao pagamento da hospedagem, transporte e alimentação, eles buscam também entretenimento, cultura, lazer e demais produtos turísticos, fazendo com que a demanda da região receptora se expanda.

Outro fator relevante do turismo na economia é o efeito multiplicador, pois para um serviço ser prestado ao turista, vários setores da economia são movimentados de forma que ocorra um aumento da demanda e por conseqüência da oferta de produtos ligados à atividade turística.

Sachs(2000) traz uma idéia interessante de sustentabilidade e economia, onde ele cita que: "O uso produtivo não necessariamente precisa prejudicar o meio ambiente ou destruir a diversidade, se tivermos consciência de que todas as nossas atividades econômicas estão solidamente fincadas no ambiente natural” (SACHS, 2000, p.32).

\subsubsection{Turismo como Atividade Econômica Brasileira}

Estudos do Ministério do Turismo realizados em 2005 apontaram 241 regiões turísticas, nas quais existem 3.924 municípios com potencial turístico que podem vir a se transformar em produtos turísticos integrantes de grandes roteiros. Formosa está nessa lista de municípios. (BRASIL, MINISTÉRIO DO TURISMO, 2006, p 19.) 
Já em 2006 a situação se mostrou completamente outra, como é citado no sitio do "Programa Nacional de Turismo - 2007 a 2010" - Uma viagem de inclusão:

\begin{abstract}
Em 2006, as 200 regiões turísticas brasileiras organizaram e apresentaram, no Salão do Turismo - Roteiros do Brasil, 396 roteiros turísticos, envolvendo 149 regiões turísticas e 1.207 municípios de todas as Unidades da Federação. Desses 396 roteiros, 87 foram priorizados pelas Unidades da Federação, para obtenção de padrão de qualidade internacional e, conseqüentemente, promover o alcance das metas do PNT 20032007. Deste então, o foco de atuação do Ministério do Turismo MTur - em especial do Programa de Regionalização do Turismo e suas entidades parceiras em âmbitos nacional, estadual, regional e municipal - são os 87 roteiros que contemplam 474 municípios de 116 regiões turísticas.(BRASIL, Ministérios do Turismo, p.03).
\end{abstract}

Esses dados mostram não somente o bom crescimento do setor em menos de dois anos, mas também a maneira como o Brasil está buscando se solidificar como um grande destino turístico, por meio deste programa e suas metas.

No Brasil o turismo ocupa atualmente o $5^{\circ}$ lugar na pauta de exportações brasileiras, atingindo no ano de 2005 o valor de US\$ 3,861 bilhões equivalendo a 93,24\% acima do montante de 2002 e 19,83\% superior ao obtido em 2004 colaborando dessa forma para o desenvolvimento da economia brasileira. (BRASIL, MINISTÉRIO DO TURISMO, 2006.)

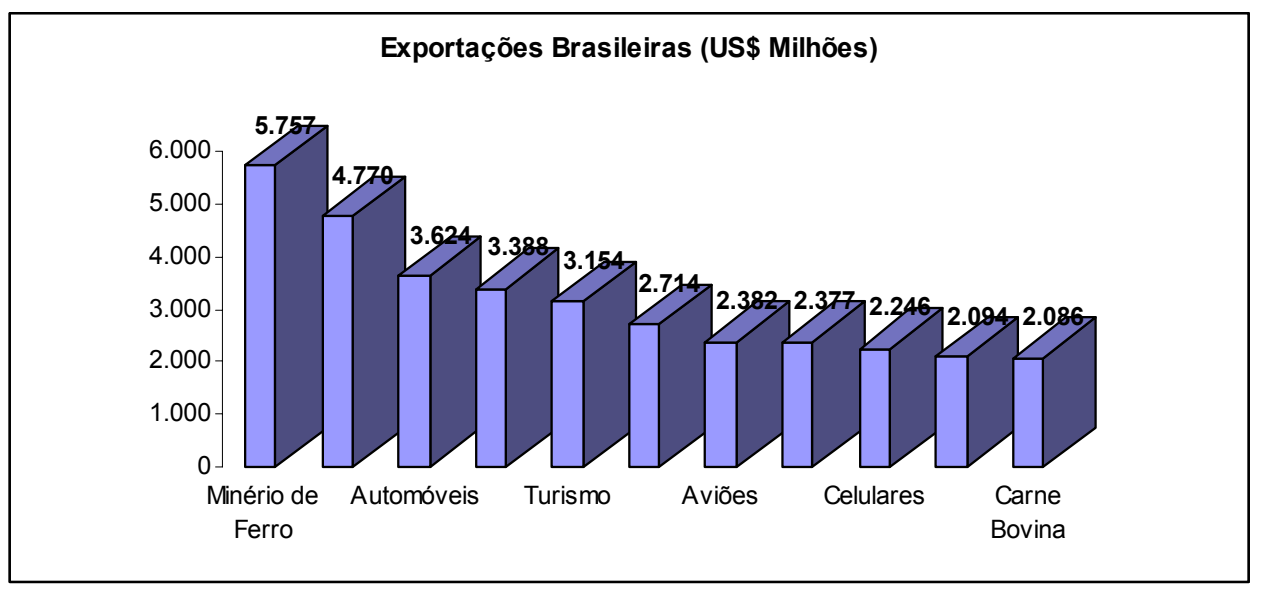

Fonte: Brasil, Ministério do Turismo, 2006

Partindo de uma visão temporal, nota-se que num período de 10 anos, o Brasil avançou significativamente no turismo interno e externo. No ano de 1995, 3,35 milhões de passageiros provenientes de outros países chegaram ao país. Já no ano de 2005 este número alcançou 6,78 milhões, mas em 2007 o número de desembarques teve uma queda de 3,33 milhões, chegando a 3,45 devido a crise 
aérea que ocorreu no país e no mundo nesse período, como demonstra a gráfico abaixo (INFRAERO).

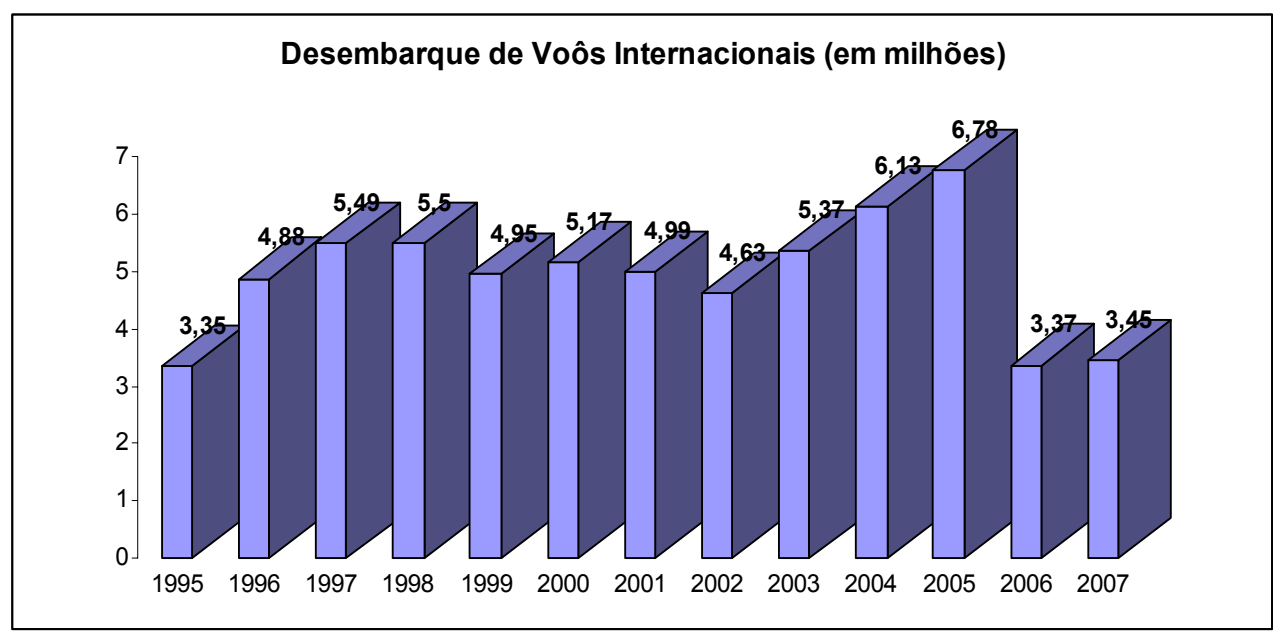

Fonte: Brasil, INFRAERO, 2008

As viagens nacionais em 1995 não ultrapassaram o número de 16,8 milhões de desembarques, já em 2005 este número atingiu a marca de 43,1 milhões. Em relação a 2005 os números de 2007 chegam a 50.00 milhões, representando um aumento de 6,9 milhões em dois anos.

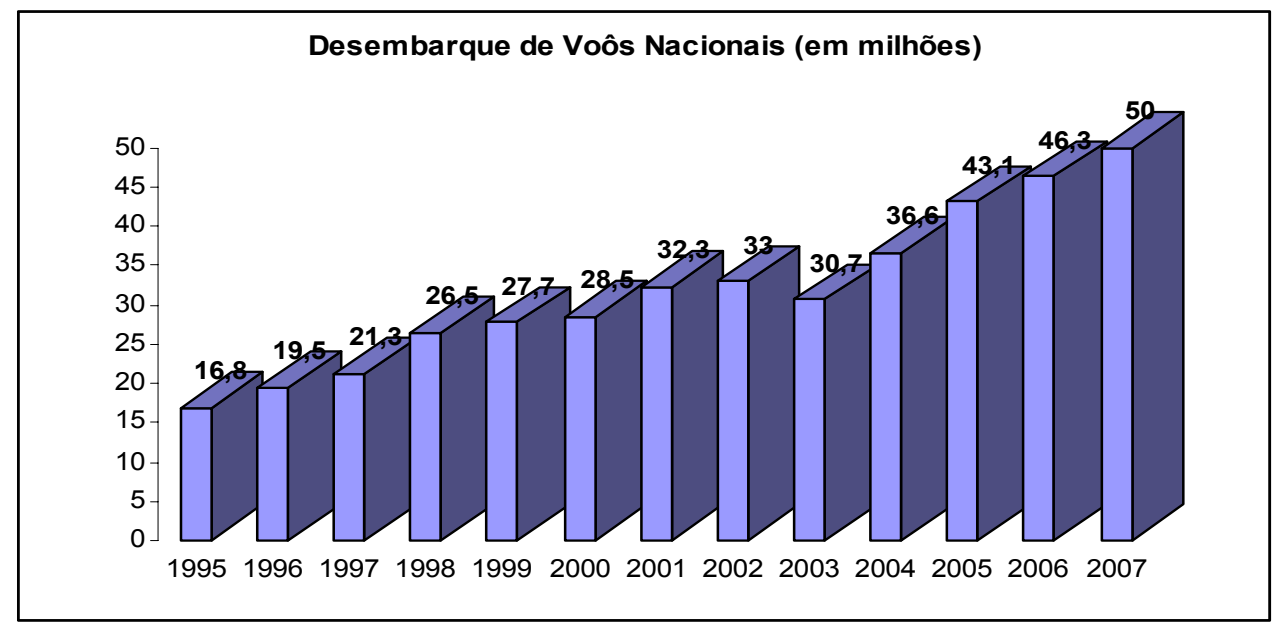

Fonte: Brasil, INFRAERO, 2008

É relevante citar que houve um aumento considerável também no número de vôos charters nacionais e internacionais nos últimos três anos.

As empresas ligadas às atividades turísticas representavam no ano de 2002 uma receita liquida total de $R \$ 67,02$ bilhões, e no mesmo período empregaram 1.426 mil pessoas, pagando a estes funcionários um total de $\mathrm{R} \$ 10.254$ milhões. Isso 
representa a importância deste segmento para o aumento da produção de renda brasileira.

\subsection{Segmentos do Turismo}

Uma outra vertente do Desenvolvimento Sustentável é o equilíbrio ecológico e segundo visita realizada ao município de Formosa e guias turísticos locais, foram levantadas algumas tipologias do turismo nos principais atrativos da localidade. São segmentos diretamente ligados ao meio ambiente, e por causa desse fator é que vem a necessidade real da sustentabilidade no desenvolvimento do turismo nos atrativos. Nas próximas linhas, o projeto trará conceituações destes segmentos encontrados.

No Manual de regionalização, elaborado pelo Departamento de Regionalização do Ministério do Turismo são encontradas as seguintes definições:

Turismo de Lazer: Segmento onde os turistas buscam a viagem por prazer, assim se abrange para qualquer lugar, Turismo que proporciona conhecimento de novos locais de descanso, lazer em decorrência de boa infra-estrutura.

Turismo Cultural: segmento onde o turista busca adquirir novos conhecimentos, onde as atrações culturais são o foco. Toda localidade trás em sua história seus costumes e tradições, que para muitos são atrativos mais interessantes, pois enriquecem culturalmente os visitantes.

Já Swarbrooke (2000) mostra o turismo cultural diretamente ligado ao turismo sustentável, tratando-os como sinônimos, pois o turismo cultural na visão dele é inteligente, sensível e suave, mesmo com alguns fatores que torne esse tipo de turismo insustentável.

Esse segmento varia sempre, pois ele estará de acordo com os ideais, com as crenças de cada região.

Ecoturismo: atividade turística onde o turista busca contemplar, interagir e conservar a natureza e suas belezas. Respirar o ar puro, registrar a fauna e a flora em fotografias, pois antes de tudo, este tipo de turista aprende a ter uma relação com a natureza de forma sustentável, incentivando sua conservação por meio de uma consciência ambientalista. 
Para Swarbrooke (2000) "ecoturismo significa simplesmente que a principal motivação para a viagem é o desejo de ver ecossistemas em seu estado natural, sua vida selvagem assim como sua população nativa". (SWARBROOKE, 2000, p.55.)

Sendo assim é um tipo de turismo que está diretamente ligado à natureza, o que o torna um segmento que precisa ser bem estruturado, para que o uso dos atrativos naturais não se tornem predatórios, mantendo e conservando de forma consciente.

"Turismo de Aventura compreende os movimentos turísticos decorrentes da prática de atividades de aventura de caráter recreativo e não competitivo".(BRASIL, MINISTÉRIO DO TURISMO, 2006).

Segmento onde os turistas buscam fortes emoções, como exemplo, pode-se citar a prática de rapel, tirolesa, vôo livre. Esta atividade é praticada em contato com a natureza e por isso é comumente ligada ao ecoturismo.

Turismo Rural: atividade desenvolvida em áreas rurais, resgatando as origens do nosso povo. Essa atividade acontece em Formosa por esta região apresentar uma economia agrícola. Existem no local empreendimentos voltados para este tipo de turismo, onde o turista estará em contato com a natureza para poder andar a cavalo, tirar o leite direto da vaca, em alguns casos passear de charrete.

\subsection{Plano de Divulgação}

Para o bom desenvolvimento das atividades turísticas em uma localidade, faz-se necessária a elaboração de um plano de trabalho que leve em conta o planejamento cuidadoso das ações a serem implementadas. No que se refere ao aumento do fluxo de turistas, é fundamental que se promova efetiva divulgação dos atrativos. Para tanto, neste trabalho propõe-se um mix de marketing.

De acordo com Valls (2006),

O marketing compreende a análise dos dados do mercado para elaborar as experiências que os turistas buscam; ajustar adequadamente a oferta; selecionar os canais de comercialização e os instrumentos de comunicação do destino; e fomentar a busca de sugestões e queixas dos clientes como fonte de melhoria (VALLS, 2006, p.77)

A partir dessa definição entende-se que o marketing é a fachada da localidade, que precisa ser impecável e buscar as melhores maneiras de chamar a atenção do cliente, que no caso de Formosa é o Turista. 
Zardo (2003) ressalta que "o objetivo do marketing é tornar a venda supérflua. É conhecer e compreender o cliente muito bem, de modo que o produto ou serviço se ajuste a esse cliente e a venda aconteça por si própria" (ZARDO, 2003, p.86).

Ou seja, ter como objetivo apenas a venda não tornará o produto interessante, esse precisa ser bem trabalhado para que o turista desperte o seu interesse para a compra, o uso e a fidelidade com o produto.

Para se chegar a esse objetivo são necessárias algumas medidas que podem ser tomadas com base em um Mix de marketing que segundo Swarbrooke e Horner (2002),

é o conjunto de varáveis que a organização pode alterar, a curto e longo prazo, para satisfazer as exigências de seus clientes. O marketing mix é composto de produto, preço, ponto de venda e promoção. Esses quatro componentes do marketing mix podem ser ajustados, de maneira individual ou em conjunto, com um ou mais dos outros componentes (SWARBROOKE e HORNER, 2002, p.239).

Para este projeto que visa aumentar o fluxo de turistas no município e tendo isso como ideal, melhorar a qualificação da mão de obra local por meio do turismo sustentável é a idéia inicial. Serão discutidas maneiras de promover o ecoturismo, o turismo de aventura, e o turismo rural de forma sustentável. Tudo isso para o melhor atendimento ao turista, melhoria na economia local, trazendo maiores divisas ao município, por meio de um turismo que promova a localidade de maneira que os impactos ambientais e cultural sejam menores e tornem o turismo duradouro. 


\section{II - DESENVOLVIMENTO SUSTENTÁVEL}

Para este trabalho as conceituações mais valiosas são as de Desenvolvimento Sustentável, e Desenvolvimento Sustentável do Turismo, pois essas idéias serão a base para a implementação do projeto.

O site do Instituto EcoBrasil, sociedade civil sem fins lucrativos criada em 1993, cuja missão é "fazer do Brasil um destino turístico confiável e sustentável," traz um pouco da história do Desenvolvimento Sustentável, e suas influências no Brasil. Segundo as informações deste site, em 1983 foi encomendado pela Assembléia das Nações Unidas um relatório à Comissão Mundial sobre Meio Ambiente e Desenvolvimento, que deveria mostrar a situação das áreas ambientais nessa época e também trazer alternativas para o melhor aproveitamento e conservação de áreas muito desgastadas.

Esse relatório só foi divulgado em 1987 pela comissão especial "Nosso Futuro Comum" e foi a partir dele que o termo Desenvolvimento Sustentável passou a ser reconhecido, se tornando uma linguagem internacional.

Nesse documento já estavam contidas as três vertentes fundamentais para o deslanchar dessa idéia. Essas três vertentes principais são: crescimento econômico, eqüidade social e equilíbrio ecológico, que serão melhor discutidas no decorrer deste capítulo. E assim a partir desses três pontos, difundir o desenvolvimento sustentável no mundo se tornou uma questão essencial.

Para firmar as idéias supracitadas, o relatório Brundtland (1987) apresenta a seguinte definição: "o desenvolvimento sustentável é aquele que responde às necessidades do presente sem comprometer a capacidade das gerações futuras de responder às suas necessidades".

Diante deste conceito, o livro "Nosso Futuro Comum" acrescenta dois conceitos chaves:

O conceito de "necessidades", sobretudo as necessidades essenciais dos pobres do mundo, que devem receber a máxima prioridade; e a noção das limitações que o estágio da tecnologia e da organização social impõe ao meio ambiente, impedindo - o de atender ás necessidades presentes e futuras. (NOSSO FUTUTO COMUM, 1991, p. 46).

Para Kinker (2002) Desenvolvimento Sustentável é um fenômeno que precisa ser implementado na chamada "indústria do Turismo", por estar intensamente ligado a 
conservação do meio ambiente, meio pelo qual o turismo sobrevive direta e indiretamente. E sendo assim determinado, está atividade precisa de um acompanhamento ininterrupto.

Já Sepúlveda (2005), diz que:

Em síntese, para que o desenvolvimento seja sustentável deve ser concebido como um processo multidimensional e intertemporal, no qual a trilogia, equidade, sustentabilidade, competitividade, se apóiem em princípios éticos, culturais, socioeconômicos, ecológicos, institucionais e políticos e tecnológico-produtivos. (SEPÚLVEDA, 2005, p. 36)

Ou seja, quando o autor fala na trilogia, nada mais é do que o social, o ecológico e a economia respectivamente, trabalhando juntos de forma ética para que o desenvolvimento possa acontecer da melhor maneira. E esse é mais um autor a firmar os ideais para a sustentabilidade propostos por Sachs.

Um dos primeiros e mais importantes autores a trazer para a literatura acadêmica a idéia de desenvolvimento sustentável foi Ignacy Sachs. Um de seus livros "Desenvolvimento: includente, sustentável e sustentado" traz a seguinte definição:

O desenvolvimento sustentável acrescenta uma outra dimensão -
a sustentabilidade ambiental - à dimensão da sustentabilidade
social. Ela é baseada no duplo imperativo ético de solidariedade
sincrônica com a geração atual e de solidariedade diacrônica com
as gerações futuras. Ela nos compele a trabalhar com escalas
múltiplas de tempo e espaço, o que desarruma a caixa de
ferramentas do economista convencional. Ela nos impele ainda a
buscar soluções triplamente vencedoras, eliminando o crescimento
selvagem obtido ao custo de elevadas externalidades negativas,
tanto sociais quanto ambientais. (SACHS, 2004, p.15) A partir dessa definição mais ampla, Sachs parte para definições separadas e detalhadas de cada pilar da sustentabilidade. Esses pilares também conhecidos como critérios para a sustentabilidade são em sua totalidade oito, que ao final formam os ideais determinados para um uso sustentável da localidade turística e da comunidade local. E são eles: social, cultural, ecológico, ambiental, territorial, econômico, política (nacional) e política (internacional).

$\mathrm{Na}$ esfera social Sachs defende quatro tópicos muito importantes; que a comunidade esteja em um patamar aceitável de "homogeneidade social"; cuja distribuição de renda seja justa; com isso o emprego trará qualidade de vida seja ele autônomo ou não; mas principalmente que o acesso aos serviços e recursos sociais sejam igualitários, sem favorecer a poucos. 
No âmbito cultural, a idéia é equilibrar a inovação na localidade, mas ao mesmo tempo não deixar que a tradição se perca nessa transição; Além da necessidade de meios para que se explore a "capacidade de autonomia para elaboração de um projeto nacional integrado e endógeno". (SACHS, 2000. p. 85); e isso fazendo com que a autoconfiança apareça como uma combinação sutil mas eficaz na abertura dos ideais para o mundo.

Quando o assunto é ecológico e ambiental, a idéia é a conservação do capital natural, para que este possa ter sempre o potencial para produzir recursos renováveis e por meio dessa idéia limitar o uso de recursos não-renováveis; além de "realçar a capacidade de autodepuração dos ecossistemas naturais". (SACHS, 2000, p.86)

O respeito à diversidade da natureza e a responsabilidade de conservar essa diversidade definem o desenvolvimento sustentável como um ideal ético (KOTHARI, 1995 apud SACHS, 2000, p. 67).

Já no critério territorial, o ideal seria buscar: um equilíbrio entre as áreas urbanas e rurais observando seus meios de evolução; a melhoria do próprio ambiente urbano; meios para um desenvolvimento ambiental seguro, principalmente para as áreas mais frágeis (conservação da biodiversidade "ecodesenvolvimento").

No campo econômico, já que este setor é o que movimenta uma comunidade, devese buscar: um equilíbrio intersetorial; segurança alimentar; meios de atualização dos "instrumentos de produção" (essenciais para o bom andamento e crescimento de qualquer setor econômico); autonomia na pesquisa científica e tecnólogica; além da inclusão na economia internacional.

Os critérios de políticas nacionais e internacionais são fundamentais para o bom andamento dos demais. Por meio destes SACHS propõe que exista uma democracia, que mostre na questão dos direitos humanos uma idéia universal; a capacidade do estado de poder implementar o projeto nacional de desenvolvimento sustentável em parceria com os empreendedores; e a coesão social. Estes são os pontos a serem analisados no campo nacional.

Já no âmbito internacional as medidas a serem tomadas são de consciência mundial. Por exemplo, deve-se buscar: um sistema que garanta a paz mundial e promova a questão da cooperação internacional, executado pela ONU; 
desenvolvimento igualitário entre os países, de acordo com os princípios de igualdade(os países mais fracos devem ter o maiores direitos); controle do sistema financeiro e de negócios; o cuidado com as mudanças climáticas, além de prevenilas; proteger fauna e flora (biodiversidade) e o patrimônio global que deve ser visto como um bem da humanidade; cooperação cientifica e tecnológica internacional, ou seja, tudo que for descoberto dever ser entendido como uma herança comum da humanidade.

É importante lembrar que uma localidade só poderá exercer a sustentabilidade física, se todos ligados ao plano de desenvolvimento tiverem de fato a certeza de que as políticas de desenvolvimento estão prontas para acompanhar as mudanças dos acessos aos recursos e a distribuição de custos e benefícios. (NOSSO FUTURO COMUM, 1991).

Sachs(2000), ainda diz: "A história nos pregou uma peça cruel. O desenvolvimento sustentável é incompatível com o jogo de restrições das forças do mercado". (SACHS, 2000, p.55)

Isso ocorre porque na sua visão o mercado ainda é focado demais em lucros e de menos em qualidade e durabilidade de um produto final, o que é um ponto negativo, pois, ao invés de procurar tudo a médio e longo prazo, quer sempre em curto prazo, o que é conflitante com as leis da sustentabilidade.

Manoel Cabral de Castro cita na coletânea de texto do livro "Bases do desenvolvimento sustentável" que:

Mais que um ponto de chegada, um invólucro estanque,
desenvolvimento sustentável é um ponto de partida, uma
perspectiva multidimensional a apontar uma trilha alternativa "as
teorias e aos modelos tradicionais de desenvolvimento,
desgastados por uma série infinita de frustrações"
(BRÜSEKE,1995, p. 35 apud CASTRO, 1999, p.41).

Ou seja, a partir disso o significado de sustentabilidade deixa de ser um adjetivo retórico e talvez até honroso, para surgir por meio dele uma nova idéia teórica do que é desenvolvimento. Pois a partir de agora, a sustentabilidade aparece como um "relacionamento entre sistemas econômicos dinâmicos e sistemas ecológicos maiores e também dinâmicos, embora de mudança mais lenta". (CASTRO 1999, p. 41 apud SACHS, 1993, p.24). 
É importante ressaltar que a mudança para o desenvolvimento sustentável inicia-se com o gerenciamento das crises, levando a mudanças, às vezes, drásticas de paradigmas, trazem as pessoas para dentro da situação problema, incluindo as mesmas na crise que existe até então para que estas possam trabalhar para a melhoria e o crescimento. A partir dessa iniciativa, traçar objetivos a serem alcançados por todos, para que estes possam usufruir o resultado final, sem que persista o padrão excludente de crescimento. (SACHS, 2004).

Mas apesar de todas essas idéias de desenvolvimento sustentável, o que se vê nos dias atuais, é uma distorção completa da filosofia inicial, o termo foi muito usado e empregado de maneiras tão adversas, que de certa forma perdeu sua idéia inicial e se tornou um assunto desinteressante. (SACHS, 2000).

\section{1 - Desenvolvimento Sustentável do Turismo}

De acordo com a Organização Mundial do Turismo (2003) o turismo sustentável tem em suas bases teóricas a idéia de que para que se desenvolva da melhor maneira possível, seus recurso naturais, históricos e culturais precisam ser bem conservados, pois assim haverá um uso contínuo no presente e no futuro.

O uso desses recursos não pode trazer problemas ambientais ou socioculturais. $O$ ideal é que a qualidade do ambiente seja conservada, não deixando com que a satisfação do cliente diminua.

Desse modo o turismo depende diretamente dos atrativos, sendo eles naturais ou não naturais, estes por sua vez são recursos limitados, uma vez esgotados não voltam mais. Se isso acontecer com a maioria dos atrativos a conseqüência será um futuro incerto para o turismo, podendo este se extinguir dependendo da situação. Por causa desse fenômeno a conservação destes produtos turísticos se torna essencial por meio do desenvolvimento sustentável, tanto para a sustentabilidade do local, do meio ambiente, bem como para o desenvolvimento progressivo do turismo.

Segundo a Organização Mundial do Turismo, em seu guia de Desenvolvimento do turismo Sustentável,

Garantir a sustentabilidade do turismo tornou-se o desafio principal daqueles que estão comprometidos com 0 desenvolvimento e o gerenciamento desse ramo de atividade, cujas taxas de crescimento nas próximas décadas serão, no mínimo, certamente semelhantes às apresentadas nos últimos 25 anos deste século. ( OMT, 2003) 
Ou seja, mais uma vez fica evidente a necessidade do uso do desenvolvimento sustentável no turismo, pois o aumento do fluxo de turistas nas localidades provoca um desgaste ao meio ambiente, tendo o desenvolvimento com base na sustentabilidade os atrativos poderão ser melhor conservados, com menos danos à localidade.

Percebe-se que sempre que o tema turismo é abordado a idéia de desenvolvimento sustentável da atividade turística vem à tona. Discutir turismo muitas vezes é tratar de desenvolvimento sustentável. Trazer a sustentabilidade se tornou algo primordial para a implementação de vários empreendimentos turísticos, assim os empresários puderam perceber que seus negócios poderiam se tornar mais duradouros.

De acordo com Petrocchi (1998), a idéia de turismo sustentável se tornou parte necessária da gestão do turismo, pois esta, para acontecer da melhor maneira possível depende diretamente da conservação do meio ambiente. $E$ isso se deve à necessidade de manter o turismo como atividade econômica.

Para De Rose (2002), o Turismo Sustentável está amplamente ligado à utilização consciente dos recursos ambientais, garantindo com isso a exploração sem a degradação dos recursos naturais, possibilitando a utilização destes recursos por futuras gerações. ( DE ROSE, 2002 p.51)

O turismo está diretamente ligado ao meio ambiente, e hoje deve-se ter uma grande preocupação quanto a conservação desse meio, principalmente para o Brasil que, segundo Petrocchi (1998), "é dotado de oito mil quilômetros de litoral e natureza exuberante em ecossistemas como o da Amazônia e do Pantanal, entre outros." (PETROCCHI, 1998, pág. 60.)

Todos esses conceitos são necessários, pois tendo o meio ambiente como principal fonte de recursos para o turismo, chega-se a questão da escassez da matéria. Segundo a teoria do consumidor de Swarbrooke e Honer (2002) existem dois tipos de necessidades, as básicas que são: alimentação e vestuário, e a dos desejos supérfluos. Dentro dessas necessidades estão os recursos que são por natureza limitados, e em contra ponto os desejos que são ilimitados. A partir daí surge a necessidade de escolha por parte dos consumidores.

Essa relação acontece no turismo da seguinte forma: os produtos turísticos dependem diretamente destes bens para sobreviver, e certo atrativo tendo uma 
capacidade limitada de uso, deve-se sugar o máximo que este pode oferecer, cabendo essa tarefa aos empresários e consumidores. Seja esse atrativo cultural ou natural se não houver um uso sustentável, o produto turístico não dura muito tempo, se desgasta facilmente o que não é muito interessante para a atividade turística, muito menos para o meio ambiente, principalmente porque, até que se esgotem totalmente esses recursos, o homem terá sempre outra localidade para usufruir. 


\section{III - O MUNICÍPIO}

\section{1 - História do Município}

Os primeiros registros de ocupação do município de Formosa datam uma época bem antiga. Esta população era um grupo primitivo conhecido como autóctones que habitavam terras que hoje são fazendas. A comprovação da presença destes habitantes nessa localidade é dada pela existência de pinturas rupestres encontradas principalmente em um dos atrativos mais conhecidos em Formosa, o Buraco das Araras. Esse dado pode ser encontrado no projeto se liga no futuro, que foi realizado pelo governo do estado de Goiás em julho de 2004.

Depois de comprovada a existência dessa população, passaram-se muitos anos até o próximo registro de ocupação dessa área. O momento agora é século XVIII, essa região do Goiás que irá se tornar o Município de Formosa, pertence à capitania de São Paulo e por ela passam vários viajantes que em busca de riquezas atravessam essa região rumo à Bahia.

Por conta da circulação de pessoas nessas terras, em fevereiro de 1736 instalou-se a Estação Fiscal Registro Lagoa Feia, por ordem do rei de Portugal, com o propósito de controlar as cobranças fiscais das mercadorias que por ali passavam, principalmente o ouro. Algum tempo depois outro registro foi instalado a cerca de $90 \mathrm{~km}$ de onde fica a atual cidade de Formosa.

A partir desses registros constata-se a formação de um povoado, onde tropeiros e comerciantes que passavam por ali começaram a montar cabanas, que serviam de ponto de descanso para esses viajantes. Além dos comerciantes, a história registra o fato de que existia um arraial nas proximidades do vale do Paranã, o Arraial de Santo Antônio que pela localidade deste ser muito insalubre e por começar a surgir uma forte epidemia de malária, seus habitantes, que eram criadores de gado com seus empregados e escravos, buscando uma melhor qualidade de vida, migraram para as proximidades do registro da Lagoa Feia.

O povoado então foi batizado de Arraial do Couro em homenagem aos viajantes que eram garimpeiros, boiadeiros e comerciantes que viajavam da Bahia para Minas Gerais e acampavam no local em barracas de couro que eles traziam para comercializar. Arraial dos Couros foi o primeiro nome de Formosa, criada na 
segunda metade do século XVIII. O clima e a oportunidade de negócio deram ao Arraial dos Couros o impulso final para se tornar definitivamente um povoado.

Em $1^{\circ}$ de abril de 1833, o arraial passou finalmente a Julgado de Couros, ato este feito pelo Conselho Geral do Governo da Província de Goiás, e até então ainda pertencia ao município de Luziânia. O então Julgado era conhecido como um grande centro comercial na região, fazendo com que em 1838 fosse elevado â Freguesia.

Foi quando em fevereiro de 1844, devido as suas belezas naturais e em homenagem à Imperatriz D. Tereza Cristina a localidade passou a ser conhecida como Vila Formosa da Imperatriz, passando a cidade em 1877, com o nome de Formosa da Imperatriz, para então chegar a como é conhecida hoje, Formosa.

O primeiro prefeito de Formosa foi Lázaro de Melo Álvares, que presidia a primeira Câmara Municipal de Vereadores. Ele cortou definitivamente a ligação que existia entre Formosa e Luziânia dando ao novo município a tão sonhada autonomia política.

A população hoje é uma mistura de pessoas de diversas nacionalidades e de diversos lugares do Brasil, que buscaram em Formosa sucesso nas atividades comerciais e na agropecuária.

\section{2 - Caracterização da Região}

Formosa está localizada na região Sudeste de Goiás, pertencendo a região CentroOeste do Brasil, está distante $280 \mathrm{~km}$ da capital do Estado, Goiânia, e a $79 \mathrm{~km}$ da cidade de Brasília, e tem como principais vias de acesso as rodovias BR-020, saindo de Brasília, BR-060 saindo de Goiânia. Formosa encontra-se na mesoregião do leste goiano e na microrregião de Brasília.

A altitude da região é de 918 metros do nível do mar e tem uma temperatura média de $25^{\circ}$ C. O Município de Formosa tem uma área de 5.806,891 km²( IBGE,2002 apud SEPLAN), com seu relevo formado por extensos chapadões e terras vermelhas, tendo ainda variações com lugares baixos e planos elevados.

Apresenta um clima tropical chuvoso e tem duas estações bem definidas, altas temperaturas e chuvas fortes e outra com baixas temperaturas e seca. O município encontra-se no alto topográfico e por isso é um divisor de águas, possuindo três grandes bacias hidrográficas, Paraná, São Francisco e Tocantins. 
Formosa possui muitos aqüíferos subterrâneos que fazem parte desse grande potencial hidrográfico do município e alguns já apresentam sinais de poluição devido a má utilização do meio ambiente pelo homem.

Do ponto de vista geográfico, o município encontra-se à $15^{\circ} 32^{\prime} 14 \mathrm{~S}$ de latitude, $47^{\circ}$ 20’04W de longitude, a uma altitude média de 918m. De toda sua área, o espaço composto pela zona urbana é de apenas $20 \%$.

\section{3 - Aspectos Socioeconômicos}

Segundo o IBGE, em 2007, sua população estava estimada em 90.212 habitantes. Muitos moram no município desde que nasceram e outros mudaram mais tarde de lugares distantes ou municípios vizinhos, influenciando na cultura e nos vários setores da economia do município. Sua população hoje é composta por: turcos, gaúchos, paranaenses e paulistas na agricultura, holandeses, franceses e italianos na religião e no ensino.

Em relação a densidade demográfica, foram encontrados dados no censo do ano de 2000 e, segundo esse estudo, o município possui uma baixa ocupação, tanto na área rural como na urbana, mas a predominância é urbana com $88 \%$ da população total em 2000. Sua densidade total é de $15,9 \mathrm{hab} / \mathrm{Km}^{2}$ e a densidade urbana é de 34,6 habitantes por hectare, uma das mais baixas da região do Goiás. (IBGE, 2006 apud SEPLAN)

A população urbana é em sua grande maioria do sexo feminino, representando $50,8 \%$. Mais quando se fala da região rural a maioria da população é do sexo masculino sendo representada por $55,5 \%$. Na questão da faixa etária a pirâmide apresenta a base maior que as outras partes, sendo $45 \%$ crianças e jovens, $43,4 \%$ de adultos e $11,6 \%$ de idosos, com mais de cinqüenta anos.(IBGE, 2000)

Um dado social importante é que até o ano 2000 cerca de $12 \%$ da população era analfabeta, e não existe dados mais atuais a respeito desse assunto. A rede de ensino conta com 81 escolas totalizando um número de 27.700 estudantes que freqüentam escolas públicas e privadas com predominância das escolas públicas, igualmente divididas nas zonas urbana e rural. Formosa ainda conta com três estabelecimentos de ensino superior, mas a maioria dos estudantes que concluem o ensino médio, ainda buscam estabelecimentos no Distrito Federal. (IBGE, 2006 apud SEPLAN) 
No assunto renda, a maior parte da população sobrevive com até três salários mínimos, representando $84,2 \%, 41,1 \%$ não tem rendimento algum e apenas $3,1 \%$ tem salário superior a 10 salários mínimos. O setor que tem maior representatividade na economia é o terciário que concentra $84,7 \%$ da mão de obra local, e depois vem o setor secundário com $12,2 \%$ da população ativa trabalhando nele. (SEPLAN, 2007)

O comércio é o tipo de ocupação predominante na região, que representa aproximadamente $9,6 \%$ da população. As empresas familiares são predominantes em Formosa e, segundo a Secretaria do Trabalho, cerca de $24 \%$ da população ativa trabalha do Distrito Federal.

A atividade que melhor caracteriza o município é a da agropecuária, ou seja, setor primário, apesar da população ter sua renda advinda do setor terciário. O cultivo de arroz e a prática da pecuária de corte são tradicionais na cultura de Formosa. A atividade industrial é representada pela indústria extrativista de transformação e construção civil e gera cerca de 704 empregos formais por meio de 109 estabelecimentos industriais. (IBGE, 2006 apud SEPLAN)

Segundo dados de 2005 do IBGE, Formosa possui um PIB de 428.722,00 e o per capita é de 4.725,00. E em 2000 o Índice de desenvolvimento Humano municipal era de 0,750 .

Na saúde, formosa esta representada principalmente por uma boa rede de saúde com hospitais, ambulâncias e postos de saúde, além de uma unidade do SAMU, e todos com cadastro no SUS. Essa rede hospitalar conta com sete hospitais que oferecem a sua população 197 leitos. (IBGE, 2007 apud SEPLAN). Comparando ao estado do Goiás essa quantidade esta acima da que possui a região administrativa, mas ainda é a metade do necessário quando se fala na relação leito por habitante.

Quanto ao serviço de abastecimento de água, cerca de $77,4 \%$ da população é atendida, segundo dados do IBGE de 2000, uma extensão de rede de 298.866m. Toda a drenagem da cidade vai para o córrego do brejo, que deságua na Lagoa Feia. O serviço de limpeza urbana é regular no município.

Na parte de fornecimento de energia elétrica, a empresa responsável é a CELG Centrais Elétricas do Goiás, que oferece o serviço para aproximadamente $33 \%$ da 
população, e atinge todas as classes de consumidores, o que engloba: área rural, órgãos públicos, indústrias, residências e comércios.

A polícia é composta por um batalhão, com um efetivo de mais de 200 policiais formam a segurança de Formosa, com uma delegacia, um presídio além da Companhia do Corpo de Bombeiros.

O sistema viário na localidade não é completamente regular, pois devido à falta de planejamento urbano, a cidade conta com ruas e variações acentuadas o que torna a passagem dos ônibus mais difícil. Assim o sistema que é regular passa pelas principais avenidas da cidade, que são as de ligação entre os bairros. Formosa também possui uma rodoviária que tem três linhas de ônibus locais e uma linha Formosa - Brasília que sai a cada hora.

\section{4 - Arte Cultura e Tradição}

Formosa proporciona aos seus visitantes uma volta ao passado, com importantes traços culturais que remetem as culturas da região do Goiás. Por não ser uma cidade muito grande e ainda ter traços de cidade de interior, seus costumes e tradições ainda estão muito ligados a crendices, lendas e folclore em geral e principalmente a religião.

Quando o assunto é cultura, Formosa tem uma bagagem muito grande e forte deixada por seus fundadores. A produção artesanal representa esse ponto, e o momento em que ela foi melhor representada foi na inauguração da feira de artesanato em $1^{\circ}$ de agosto de 2003, em homenagem ao aniversário de 156 anos da cidade, nela poderia se comprar de tudo, desde produtos alimentícios, até vestuário, tudo sempre ligado aos costumes da cidade. A iniciativa foi interessante e ajudou vários artesãos do município que não tinham onde expor seus trabalhos para comercializar e proporcionou também um fortalecimento na economia da cidade.

Mas apesar de ter se tornado um ponto de encontro para os moradores, pois todos voltaram a se encontrar aos domingos na praça da cidade relembrando tempos antigos, teve seu fim muito rápido, sendo presente no cotidiano de seus moradores por um curto período de aproximadamente 1 ano.

Um ponto muito interessante que foi resgatado por essa feira de artesanato, foi a culinária local, as comidas típicas do Goiás. Contando com uma variedade enorme, e uma mistura de hábitos alimentares indígenas (alimentação a base de milho e 
mandioca), e de duas regiões do Brasil que como falado anteriormente foram as regiões que mais trouxeram emigrantes para essa região, Minas e São Paulo.

Para exemplificar, segundo o site centro-oeste, na parte de culinárias típicas das regiões, as comidas mais conhecidas são: galinhada (arroz com galinha) com pequi ou guariroba, empadão goiano (empada com recheio de frango, carne de porco, lingüiça, guariroba e queijo), peixe na telha (surubim ou pintado preparado em recipiente de barro pode ser assado ou cozido ao molho), arroz com suã (espinha de porco), angu (um tipo de mingau feito com polvilho de milho que pode ser temperado com sal, pimenta e cheiro-verde ou servido no seu natural), pamonha (feita com massa do milho verde pode ser temperada com açúcar, creme de leite e queijo ou com sal, lingüiça, pimenta - a pamonha pode ser preparada utilizando-se a própria palha do milho onde é colocada sua massa e cozida em água fervente, assada ou frita), curau (mingau feito com o polvilho do milho e leite), pirão (farinha de mandioca preparada com caldo de costela de vaca, frango ou peixe).

A cidade de Formosa conta ainda com um casarão que foi doado pela prefeitura para compor o centro de cultura, tradição e turismo de Formosa. Nele estão três pontos culturais da cidade, o museu dos couros, a galeria de arte e o teatro. No museu estão relíquias doadas pela sociedade que contam a história da cidade desde sua criação, que datam de quando ainda era Arraial dos Couros, por isso o nome Museu dos Couros. A galeria conta com obras de artistas de Formosa que mostram a cultura e a história da localidade. O teatro foi inaugurado em 2003, e é muito pouco utilizado pela comunidade, muito raramente acontecem eventos no local.

Um fato interessante que remete à cultura da cidade é uma de suas festas mais tradicionais, a exposição agropecuária, que acontece no dia do aniversário de Formosa, desde 1950, considerada uma das maiores do estado do Goiás e sempre com o mesmo intuito de expor animais, mercadorias produzidas na região, com rodeio, leilões, competições de diversas categorias, eleição da rainha da exposição além dos vários shows promovidos na festa. É realizada devido a ajuda da prefeitura e do sindicato dos produtores rurais da cidade.

Outra festa realizada na cidade é a da Moagem, que acontece em junho. Antigamente ela acontecia na cidade a cada safra. Hoje ela ocorre em um bairro 
com o apoio da prefeitura e de outras empresas de Formosa. É uma festa que busca a benção na próxima safra para que nada de ruim aconteça.

Como dito anteriormente, Formosa ainda é uma cidade interiorana, sendo assim, as lendas e o folclore ainda são fortes na cultura e dentro desta, os cidadãos mais velhos adoram contar lendas que fizeram parte do seu cotidiano e agora passam para suas próximas gerações.

Além dessa cultura carregada de tradição, os eventos também fazem parte desse cenário. Formosa tem uma agenda com atividades, shows e campeonatos, que em alguns casos, são eventos que fazem parte do cenário nacional, tendo uma de suas etapas na cidade de Formosa, que é o caso do campeonato de vôo livre, onde os competidores partem de Formosa rumo a Esplanada dos ministérios em Brasília. Além desse tem o campeonato goiano de Motocross, shows de manobras radicais, campeonato goiano de Jet Sky e o encontro de pará-quedismo. A maioria acontece com o apoio da prefeitura e estão todos separados durante todos os meses do ano.

\section{5 - Atrativos e Potenciais Naturais e Ecológicos}

Formosa apresenta importantes atrativos e potenciais naturais e ecológicos, que chamam a atenção por suas belezas e caracterizam a região como uma área de relevante importância para a biodiversidade do país. Analisaremos a seguir as principais potencialidades do município de Formosa, levantados por meio de visitas técnicas ao município e coleta de informações em publicações especializadas.

\subsection{1 - Salto do Itiquira}

O município de Formosa possui o Complexo do Itiquira, que é formado pelo salto e pela Estância do Itiquira. O Complexo localiza-se a $34 \mathrm{~km}$ da cidade de Formosa, seguindo pela GO-116, o trecho é totalmente asfaltado, nesta estrada existe o restaurante Dom Fernando que possui comidas típicas e cavalgadas. Este é considerado um dos melhores restaurantes da cidade.

O Salto do Itiquira possui 168 metros de queda livre e é considerado o mais alto da América Latina, é formado pelo Rio Itiquira cujo curso d'água passa por todo o parque e é de preservação ambiental. Para visitar o salto é necessário pagar uma taxa de $\mathrm{R} \$ 10,00$, ele possui um amplo estacionamento, restaurante e um local para piqueniques e churrascos, situado atrás do restaurante. 
Antes de chegar ao Salto do Itiquira há a estância do Itiquira que é um clube restrito a sócios e dependentes. Lá se pode usufruir de duas maneiras, uma é o clube que é aberto diariamente onde existe área com piscina, sauna e restaurante, e área de camping. Outra são os chalés, onde o sócio aluga o chalé e pode usufruir um barrestaurante, piscina com toboágua, sauna, hidromassagem, além de contar com uma vista panorâmica para o Salto do Itiquira.

\subsection{2 - Cachoeiras do Indaiá}

As cachoeiras do Indaiá localizam-se na microbacia do Itiquira, é conhecida por este nome, pois nas proximidades existe uma empresa que utiliza sua água para comercialização. $O$ acesso às cachoeiras é pela rodovia Formosa - Planaltina de Goiás a uma distancia de $28 \mathrm{~km}$ sendo $20 \mathrm{~km}$ em trecho asfaltado e $08 \mathrm{~km}$ em trecho de terra.

Para conhecer as cachoeiras é preciso pagar uma taxa, onde o preço não é fixo. Tem-se acesso somente a primeira queda d'água e para conhecer as outras é preciso de acompanhamento de guia ou de alguém que conheça a trilha. O local não possui guias. Uma das quedas d'água mais conhecida é a véu de noiva, onde pratica-se rapel, esta queda d'água é umas das mais perigosas porque já houve casos de morte.

O percurso pode ser feito em aproximadamente 4 horas. No final da trilha, dentro do parque municipal do Itiquira, há um mirante no topo do salto onde pode-se ver toda a beleza do Salto do Itiquira e a imensidão do Vale do Paraná.

Próximo ao Indaiá existe um camping com, playground, churrasqueiras, banheiros, piscinas e a área para o a armação das barracas.

\subsection{3 - Buraco das Araras}

O Buraco das Araras é o resultado de um desabamento da superfície de uma caverna, onde houve um desgaste devido a ação da água, provocando o dissolvimento do calcário existente no local, o que o leva a ser conhecido como Dolina, com 972 metros de diâmetro e cerca de 95 metros de profundidade. Essa cratera foi formada em meio a uma paisagem campestre de cerrado fino. Possui uma vegetação densa, composta basicamente por pteridófitas, que são samambaias capazes de medir até 5 metros. Após uma longa caminhada em uma trilha íngreme que não é de fácil acesso, é necessário muita atenção por dentro da mata densa e 
úmida, entre o verde abre-se espaço para a entrada de uma caverna que em seu interior se encontra um lago subterrâneo de águas cristalinas.

A caverna guarda também grandes formações de estalactite ${ }^{4}$ e estalagmite ${ }^{5}$. É conhecido como Buraco da Araras por alojar durante a noite pássaros dessa espécie.

O Buraco das Araras se distancia de Brasília $100 \mathrm{Km}$ e de Formosa uns $40 \mathrm{Km}$ seguindo pela BR-020 ao norte, cerca de $4 \mathrm{Km}$ do Distrito de Bezerra, sendo mais $9 \mathrm{Km}$ de estrada de leito natural.

Este é o local mais procurado por pessoas que gostam de esportes radicais e ecoturistas. O primeiro devido ao seu imenso paredão, pois, uma outra maneira de chegar à entrada da caverna é descendo cerca de 95 metros de queda, sendo 15 metros com o apoio do paredão e o restante em decida negativa, que é como é conhecida a decida sem apoio. Principalmente amantes desse esporte podem ser encontrados lá todos os fins de semana, quando o clima está favorável para a sua prática.

E o segundo é devido a beleza natural do local. A trilha por dentro da mata fechada, que leva a entrada da caverna, mostra espécies de samambaias gigantes que podem chegar a medir 5 metros de altura e as formações calcárias que levam centenas de anos para se constituírem. O mais importante nessa aventura é o respeito e o cuidado que todos devem ter com o local, pois essas formações são muito frágeis e delicadas. O que também chama a atenção desses adoradores do ecoturismo são os animais que habitam a caverna, além também da bela paisagem que pode ser vista no alto do buraco, uma imensa depressão no meio do cerrado fino.

\subsection{4 - Gruta das Andorinhas}

A Gruta das Andorinhas é uma depressão no alto de uma montanha que foi formada por causa de um desmoronamento de pedras calcárias. Ela está cercada de

\footnotetext{
${ }^{4}$ Estalactites são formações rochosas sedimentares que se originam no teto de uma gruta ou caverna, crescendo para baixo, em direção ao chão da gruta ou caverna, pela deposição de carbonato de cálcio arrastado pela água que goteja do teto. (PORTAL WIKIPÉDIA, Disponível em: http://pt.wikipedia.org/wiki/Estalactite Acesso em: 13.nov.2006.)

${ }^{5}$ Estalagmites são formações que crescem a partir do chão de uma gruta ou caverna em direção ao teto, formadas pela deposição de carbonato de cálcio arrastado pela água que goteja do teto. (PORTAL WIKIPÉDIA,Disponível em: http://pt.wikipedia.org/wiki/Estalagmites. Acesso em: 13.nov.2006.)
} 
vegetação densa, possui 80 metros de diâmetro e 100 metros de profundidade. Na lateral está localizada a entrada da caverna, que possui uma decida íngreme de pedras calcárias e no final um grande rio onde ao atravessá-lo poderão ser encontradas algumas galerias escondidas por entradas estreitas. Dentro da caverna encontram-se três trampolins naturais que estão localizados mais ao fundo, um com 5 metros de altura, um com 8 metros e por último um de 12 metros. Este último só deve ser utilizado na época que o nível da água está mais alto, por causa da grande quantidade de pedras que estão no fundo do rio. A gruta também é conhecida como - Buraco das Andorinhas e é conhecida assim por abrigar essa espécie de pássaros.

A Gruta das Andorinhas está localizada a $100 \mathrm{Km}$ de Brasília e cerca de $40 \mathrm{~km}$ de Formosa, seguindo ao norte pela BR-020, $4 \mathrm{Km}$ do município de Bezerra e $12 \mathrm{Km}$ de estrada vicinal.

A gruta é muito procurada por praticantes de ecoturismo, que buscam relaxar com o encontro com a natureza. Isso é feito primeiramente subindo uma trilha de pedras em meio a mata menos fechada que a do Buraco das Araras. Logo depois vem uma descida íngreme, onde o aventureiro terá que se apoiar nas pedras, e em alguns momentos escorregando nelas, pois o solo, dependendo da época do ano pode ser um pouco ou bastante escorregadio no decorrer da trilha. No final o encontro com o rio subterrâneo de água gelada e cristalina se torna um espetáculo a parte. $\mathrm{O}$ rio possui uma ilha de pedras no centro e os turistas devem ter cuidado, pois a profundidade em alguns pontos pode atingir mais de 7 metros. Basicamente tirando a parte da ilha e uns pontos ao seu redor, em nenhuma outra parte do rio o visitante irá conseguir se manter em pé, para fazer bem a trilha e poder desfrutar de um bom passeio o visitante deve ter um bom preparo físico e principalmente saber nadar.

\subsection{5 - Cachoeira da Capetinga}

A cachoeira da Capetinga é um desnível de 130 metros, sendo 100 de cachoeira, são 06 pequenas quedas onde pode ser encontrado no inicio e no final, poços de água mais parada. A trilha possui uma vista privilegiada e conta também com um mirante. Essa cachoeira é formada no rio Bisnal.

Está localizada cerca de $101 \mathrm{Km}$ de Brasília, 43Km de Formosa, indo pela BR 020 ao norte e conta ainda com $02 \mathrm{Km}$ de estrada não pavimentada. 
Os turistas procuram essa localidade para fazer o ecoturismo e turismo de aventura, pois seus 130 metros de cachoeira proporcionam, lazer, banhos e hidromassagem naturais, como também práticas de rapel.

\subsection{6 - Cachoeiras do Bandeirinha}

Localizada cerca de $5 \mathrm{Km}$ de Formosa, indo pela BR-116, 03Km sentido Itiquira, e depois alguns quilômetros por estrada de leito natural. As Cachoeiras do Bandeirinha são conhecidas assim por se formarem a partir do Rio Bandeirinha, com 4 quedas d'águas. Sendo que uma delas chega a atingir cerca de 15 metros de altura de água muito cristalina. Nessas cachoeiras pode-se encontrar poços no final da queda que são próprios para banho e atingem uma profundidade que varia entre 1,5 e 2,5 metros.

Os poços são rodeados por mata ciliar muito bem conservada, com cerrado de campos limpos e conta ainda com áreas de pastagem. O acesso é feito por trilhas em meio a mata fechada, uma das trilhas é bem escorregadia, por conta da proximidade da queda d'água. Também é conhecida como Cachoeiras do Nassin, em homenagem ao dono da fazenda onde estão localizadas as cachoeiras.

É utilizada por adeptos do ecoturismo, que buscam em suas trilhas o encontro com a natureza. Suas trilhas não são tão difíceis de serem feitas, e o banho natural no final é compensador.

\subsection{7 - Lajedo}

Este atrativo é um local que transparece tranqüilidade, já que o acabamento das rochas que cobrem o leito do rio Ribeirão formam lindas cascatas que terminam em um poço de águas transparentes. A cena convida para um dia de descanso, tudo isso cercado de vegetação típica do cerrado, a quarenta e dois quilômetros do centro de Formosa.

O local é de fácil acesso, percorre-se uma pequena trilha até a chegada em um poço com três metros de profundidade com uma área de descanso. Cobra-se uma taxa de visitante a preço acessível.

\subsection{8 - Pedreira Toca da Onça}

A sete quilômetros de Formosa (sendo seis em estrada de chão) está a Pedreira Toca da Onça. Lá se encontram mais de trinta e cinco grutas calcárias, que além de 
serem naturalmente atrativas pelas formações rochosas, são o habitat de diversas aves (inclusive araras).

Na mesma propriedade encontra-se o sítio arqueológico toca da onça, onde são encontradas pinturas rupestres que constitui-se no maior atrativo aos visitantes, pinturas com milhares de anos. Existe uma agradável trilha que permite visualizar todos essas peculiaridades do local.

\subsection{9 - Sítios Arqueológicos}

Na região encontram-se vestígios de populações primitivas do Planalto Central que podem ser conhecidas como paleoíndios. ${ }^{6}$ Eles eram grupos de caçadores-coletores que viviam em ambientes onde predominavam espaços abertos, cujas principais fontes de alimentação eram mamíferos de grande porte, alguns extintos há mais de 10.000 anos. Em determinados pontos é possível achar vestígios que retratam o cotidiano dessas pessoas. Existem trinta e cinco sítios arqueológicos no município de Formosa ${ }^{7}$. Estes são caracterizados por terem superfícies grafadas em pedras que vão desde escavações rupestres de baixo relevo até pinturas monocrômicas em tom vermelho e preto. Os mais famosos são o sitio arqueológico do Bisnau e a Gruta Catorze.

O sitio arqueológico do Bisnau é de fácil acesso e as artes primitivas são facilmente visíveis. São únicas já que são baixos relevos em rocha no solo á céu aberto. Por esses fatores a conservação é difícil já que os desenhos estão sujeitos às intempéries e expostos a interação humana. Não existe nenhum controle para o acesso ao atrativo, mas ele é devidamente sinalizado para o acesso. A potencialidade turística de sítios arqueológicos é enorme e para que tenha sucesso são necessários cuidados especiais.

\subsubsection{0 - Mata da Bica}

A Mata da Bica é um Parque Ecológico, localizado na zona central do município de Formosa, apresenta uma área de 25,68 hectares de mata nativa do cerrado brasileiro. São encontradas também algumas espécies de macacos, peixes e outros animais que compõem a fauna da região.

\footnotetext{
${ }^{6}$ UNIVERSIDADE DE SÃO PAULO, Disponível em: http://www.mae.usp.br/setora.htm.

${ }^{7}$ Instituto de Patrimônio Histórico e Artístico Nacional - IPHAN, Disponível em: http://portal.iphan.gov.br/portal/montarResultadoPesquisaSitiosArqueologicos.do .
} 
Em sua área encontram-se nascentes de um dos rios que formam a Bacia Hidrográfica do Rio São Francisco, primeiramente ela forma o Lago Mata da Bica, desaguando no Córrego Zefa Gomes que atravessa a cidade e chega até a Lagoa Feia, onde passa a compor um dos afluentes da Bacia do São Francisco. Atualmente na sede do parque funcionam a Secretaria Municipal de Agricultura, Pecuária e Meio Ambiente, e ainda a divisão de Polícia Florestal de Formosa.

Apesar de ser uma área de preservação com grande relevância para a biodiversidade local, o parque não é cuidado como deveria. Não há infra-estrutura básica que permita acesso de visitantes, as trilhas não têm sinalização, a segurança é tão precária a ponto das grades serem furtadas pelos moradores. Os poucos usuários na maioria das vezes fazem uso errado do parque, cometendo delitos como o uso de entorpecentes e a degradação da natureza. O parque acaba sendo utilizado por muitos como depósito de lixo e cemitério de animais.

Assim sendo o Parque Mata da Bica, embora seja um potencial, não pode ser considerado um atrativo para os turistas que visitam a cidade. Justamente pela inexistência de infra-estrutura em geral. Um dos poucos programas que são realizados no parque, segundo informações da Polícia Florestal, são algumas visitas guiadas, durante a semana, com alunos da rede pública de ensino de Formosa. Este programa tem o intuito de criar nos jovens a consciência que muitos adultos que fazem o uso do parque não têm.

\subsubsection{1 - Lagoa Feia}

A Lagoa Feia localiza-se à aproximadamente $5 \mathrm{~km}$ do centro de Formosa, ocupa uma área de 15.000 metros quadrados e em alguns pontos chega a ter a profundidade de até 10 metros. É formada com as águas de diversos rios que nascem na região e faz parte da nascente do Rio Preto, que compõe a Bacia Hidrográfica do Rio São Francisco.

Ao redor da Lagoa é encontrada uma mata ciliar bem preservada, sendo que na principal área de visitação existe um bosque de eucaliptos, utilizado por muitos para camping.

A infra-estrutura turística presente na Lagoa Feia pode ser considerada como boa, às margens estão localizados diversos restaurantes, bares, hotéis, áreas de 
camping, praças, um clube recreativo com playground, piscinas, pesque pague, quadras poliesportivas dentre outros.

A Lagoa Feia também é um ponto ideal para a prática de diversos esportes aquáticos como a pescaria, jet ski, canoagem, wakeboard, sky surf e passeios de lancha. São promovidos na Lagoa algumas etapas de campeonatos locais e até nacionais de alguns esportes aquáticos, isso por causa das variáveis propícias para a prática de esportes como o sky surf, por exemplo, onde além da água é necessárias boas rajadas de vento para que o esporte se torne possível.

Com isso a Lagoa Feia apresenta-se como um atrativo muito importante do município de Formosa, sendo o mais próximo ao centro da cidade. Recebe diariamente a visita de centenas de moradores e alguns turistas que aproveitam as belezas locais.

\subsubsection{2 - Lago do Vovô}

O Lago do Vovô localiza-se na Avenida Ivone Saad, foi construído com recursos da prefeitura e apresenta em si uma boa infra-estrutura para acolher os visitantes e a população, torna-se assim um lugar agradável que passou a ser um dos pontos de encontro dos formosenses.

O lago tem uma área de 5.722 metros quadrados de água, em sua orla há uma praça com passeios, bancos, uma lanchonete, um parque infantil e uma praça iluminada. O lago recebeu esse nome por ser destinado à comunidade da melhor idade formosense. Sua formação se dá pela junção de várias nascentes que deságuam no Rio Preto, que é um dos afluentes da Bacia Hidrográfica do São Francisco.

\subsubsection{3 - Berço das Águas do Brasil}

O Município de Formosa recebeu do poeta Leo Lince o título de Berço das Águas do Brasil, justamente por ter em seu território a nascente de três das maiores bacias hidrográficas do Brasil, sendo elas a Bacia do São Francisco, composta na localidade pelo ribeirão Santa Rita, Lagoa Feia e Rio Urucuia; a segunda é a Bacia do Prata, representada pelo ribeirão do Pipiripau; por ultimo a Bacia Amazônica composta na região pelo Rio Paranã e o Ribeirão Bandeirinha. 
Em sua totalidade Formosa apresenta diversas nascentes, rios, ribeirões, cachoeiras, lagos e lagoas que apresentam de forma geral um amplo potencial turístico para o município. Boa parte destes estão apresentados neste trabalho e constituem em si atrativos importantes para o desenvolvimento do turismo em Formosa e sua região.

\subsubsection{4 - Trilha do Sino}

A Trilha do Sino tem a extensão aproximada de 1.500 metros, com início na rodovia GO-116 no sentido da Serra do Itiquira. A trilha é considerada por muitos como uma das mais difíceis da região, justamente por ser uma subida íngreme que passa por diversas pontes e pinguelas. No final da trilha, há um sino que deve ser tocado por cada pessoa que conseguir concluir a trilha, por este motivo a trilha é chamada de Trilha do Sino.

Para fazer a trilha, é recomendável que os visitantes tenham um bom condicionamento físico, o local é ideal para pessoas que gostam de aventura e de um belo visual. 


\section{IV - METODOLOGIA}

Neste capítulo serão detalhadas as formas de pesquisa abordadas para a elaboração deste trabalho. Como foram feitas as entrevistas, como e para quem os questionários foram aplicados.

Para se obter o conhecimento sobre algo que se está procurando, o ato mais usado no cotidiano das pessoas é a pesquisa. Com ela buscam-se informações que venham responder às perguntas levantadas.

Esse trabalho baseou-se em pesquisa científica que se classifica em métodos e técnicas. O método é a parte mais complexa, é a explicação do todo, enquanto a técnica é mais específica, está relacionada aos vários procedimentos necessários dentro de uma pesquisa (RUIZ, 1991).

Quanto aos métodos, os instrumentos deste estudo são de caráter qualitativo, pois buscam visões de como a amostra (representantes da comunidade e do governo local) vê o turismo no município de Formosa e quais são as atitudes tomadas para desenvolver o turismo na localidade, além de uma breve avaliação dos atrativos da localidade na visão crítica da autora desta monografia.

Quanto aos objetivos desse método, a pesquisa foi exploratória e descritiva. Exploratória, pois contou com uma fase preliminar de planejamento do que seria feito. Por meio de pesquisas bibliográficas, em sites e informativos sobre a região, uma idéia do que ocorre hoje em Formosa pôde ser constatada. Essa pesquisa é interessante porque Formosa não possui ainda um conhecimento acumulado sobre o turismo no município.

Com esses dados levantados, uma idéia inicial foi formulada: a de saber qual o ponto de vista dos moradores e governantes da cidade a respeito do turismo na região. A partir dela foram elaborados questionários e entrevistas estruturadas para que esses dados pudessem ser confirmados ou não.

Essa pesquisa também é descritiva porque, houve a observação, o registro, a análise e interpretação dos dados levantados com os questionários e entrevistas. 
De acordo Vergara, "a coleta de dados serve para orientar o pesquisador quanto às informações que pretende obter para responder a problemática da pesquisa" (VERGARA, 2007 p.54).

Os procedimentos para o levantamento dos dados foram os básicos para um trabalho cientifico. Este estudo conta com uma pesquisa bibliográfica, com autores da área e uma pesquisa de levantamentos, com questionário e entrevistas com principais representantes do município para captar informações relevantes e pontos de vistas destes que moram na localidade.

Quanto à amostra, esta foi de caráter acidental e casual estratificada. Acidental, pois os questionários foram aplicados aos representantes da comunidade e do governo sem haver uma seleção prévia de quantos responderiam as perguntas. Assim, conforme os contatos que foram sendo viabilizados com os coordenadores dos programas sociais existentes em Formosa e os membros do governo local, a pesquisa foi se caracterizando e sendo executada. Por outro lado, a amostra pode ser definida como casual estratificada por pré-definir extratos da sociedade: representantes do governo, proprietários das terras e representantes da comunidade.

Com dito anteriormente, este trabalho conta com uma entrevista estruturada, onde foi elaborado um roteiro pré-estabelecido e único para os representantes do governo $^{8}$. Este roteiro, por sua vez, possui perguntas diretamente ligadas a visões sobre o turismo, gestão e quais seriam as possíveis ações que poderiam ser executas para que o turismo se desenvolva da melhor maneira e pautado nos ideais da sustentabilidade.

Além das entrevistas, foram elaborados dois questionários com perguntas abertas e fechadas e de múltipla escolha, um direcionado aos representantes da comunidade e o outro aos proprietários de terras onde estão alguns atrativos. As perguntas aos representantes foram feitas de maneira direta para entender como é a visão deles a respeito do turismo em Formosa e o que conhecem de atrativos na localidade. Já com os proprietários, as perguntas foram voltadas a como está o estabelecimento deles hoje e quais as ações que fazem a respeito da sustentabilidade.

\footnotetext{
${ }^{8}$ Essas perguntas encontram-se no apêndice D do trabalho.
} 
As entrevistas e questionários foram aplicados in loco diretamente pela autora deste estudo. O questionário com os representantes da comunidade contou com 4 perguntas aberta, 2 pergunta fechadas e 2 de múltipla escolha todas de caráter qualitativo. Já com os proprietários o questionário conta com 3 perguntas aberta (análise qualitativa), 3 pergunta fechadas (análise quantitativa) e 1 de múltipla escolha ${ }^{9}$.

Sendo assim, as etapas feitas para poder chegar aos próximos capítulos de tabulação, análise e proposição de melhorias, foram as seguintes:

$1^{\text {a }}$ fase - Determinação do problema

- Formosa possui potencial turístico que pode ser melhor aproveitado. Este dado foi levantado por meio de pesquisas bibliográficas, informações em sites e panfletos além da pesquisa de campo feita pela autora.

$2^{\mathrm{a}}$ fase - Organização e execução da pesquisa

- De acordo com o referencial teórico elaborado, foram levantados os principais fatores que poderiam promover o desenvolvimento do turismo na região e assim, questionários e entrevistas foram elaborados e executados em 4 visitas técnicas.

$3^{a}$ fase - Análise dos dados e proposições sugeridas

- Com os dados levantados, os próximos capítulos trazem a análise de cada pergunta e cada idéia colocada pelos entrevistados. De acordo com os pontos negativos que surgiram nesse processo de levantamento de dados, foram elaboradas propostas para a melhoria desses pontos, para que o turismo em Formosa possa se desenvolver da maneira mais sustentável e atinja todos os envolvidos (comunidade, governo e empresários).

\footnotetext{
${ }^{9}$ Essas perguntas encontram-se nos apêndices A, B, C do trabalho.
} 


\section{V - DIAGNÓSTICO}

Este capítulo tem por finalidade apresentar e discutir os principais apoios, pontos positivos e entraves encontrados na região e nos atrativos, assim como mostrar qual a opinião da comunidade, e dos representantes legais do governo atual (2008) sobre o tema. Detalha ainda, qual a atual situação da cidade de Formosa, discutindo a possibilidade do turismo se desenvolver na localidade.

Durante o final do ano de 2007 e primeiro trimestre de 2008 foram levantados pontos positivos e pontos negativos quanto aos aspectos citados acima. Assim, serão levados em consideração como pontos positivos todos os aspectos que implementam a qualidade de vida local e a atividade turística como um todo; já os pontos negativos são aqueles que de uma forma ou de outra não contribuem ou dificultam o pleno desenvolvimento do turismo.

A discussão desse capitulo fez-se a partir de visitas técnicas realizadas à cidade e ao município de Formosa, a fim de captar o máximo de informações a respeito da região, dos atrativos, de como a comunidade entende o turismo na localidade, e principalmente, qual é a idéia de todos a respeito da sustentabilidade. Pois essa é a idéia principal para poder implementar o turismo em Formosa.

Todo esse levantamento foi realizado por meio de entrevistas e pesquisas feitas com representantes da comunidade, alguns integrantes do governo, de programas sociais e com proprietários de terras onde estão alguns dos principais atrativos naturais de Formosa. E assim de acordo com os dados levantados, as linhas que seguem mostrarão os principais pontos a serem estudados, analisados e alguns maximizados.

\section{1 - A Cidade}

A primeira visita realizada ocorreu em dezembro de 2007. Essa visita aconteceu para observar a situação da infra-estrutura local e turística na cidade. Como estão as vias de acesso aos atrativos, e a sinalização. Como base nessa visita, o que pode ser relatado, é que Formosa possui uma sinalização para os principais atrativos, tanto culturais como naturais, é uma sinalização que segue padrões nacionais, de fácil visualização, fazendo o uso de pictogramas e encontram-se em bom estado de conservação. 
A infra-estrutura local é a de uma cidade do interior, com ruas estreitas, o que torna o trânsito mais lento e em horários de picos chega a formar engarrafamentos. Isso ocorre durante a semana, já nos finais de semana é um pouco diferente, pois muitos dos moradores saem da cidade. O saneamento básico da cidade foi inaugurado há pouco tempo, até o final de 2006 ainda não existia.

No final de janeiro de 2008, uma segunda visita foi feita, para ver a situação das vias de acesso aos atrativos naturais. A BR 020 que é a via principal que leva aos principais atrativos, foi toda restaurada, trazendo conforto e uma viagem tranqüila a quem quer desfrutar um fim de semana na localidade. É importante ressaltar que para chegar a alguns atrativos, as estradas são ainda de terra, mas de fácil acesso e circulação.

Nesta mesma visita, foi observado que a cidade possui um centro de cultura, tradição e turismo que fica aberto todos os dias. Neste centro só existe uma senhora que cuida dele, mas não tem capacitação para falar melhor sobre o que está exposto lá. É um centro onde há relíquias que datam da época de quando Formosa ainda era Arraial dos Couros; em outra sala são expostas pinturas e esculturas de artistas formosenses e na última parte, existe um teatro que conta com poucos eventos.

Formosa possui algumas praças, que são bem estruturadas. Muitas foram reformadas há pouco mais de um ano e a partir dessa reforma, houve a preocupação quanto à acessibilidade para cadeirantes: todas são adaptadas para atender essa demanda.

Na entrada da cidade existe um Centro de Atendimento ao Turista - CAT, mas este por sua vez estava fechado em todas as visitas realizadas a cidade de Formosa.

Um ponto negativo encontrado foi quando da visita feita a Secretaria de Agricultura Pecuária e Meio Ambiente, que está localizada na Mata da Bica, uma área de 25,68 hectares de mata nativa do cerrado brasileiro, as informações obtidas foi que esta área, que deveria ser de proteção ambiental, está sendo usada como esconderijo de bandido, local para uso de drogas, entre outros acontecimentos.

\section{2 - As Entrevistas}

A terceira visita aconteceu em 29 de fevereiro de 2008 onde foram feitas várias entrevistas com representantes do governo local. 
Foi com o Secretário de Desenvolvimento Econômico, o senhor Wilmar Aloísio, o primeiro contato com um representante local do governo local. Desse primeiro contato surgiu a oportunidade de uma conversa com outros representantes políticos da comunidade. São eles: o senhor Secretário Valdir Brigido Lemos, de Agricultura Pecuária e Meio Ambiente; alguns representantes dos projetos sociais que acontecem em Formosa, na Secretaria de Trabalho e Promoção social; o promotor da Cidade o Dro Frederico; o presidente da Câmara dos Vereadores o senhor Tião da Celg e um morador da cidade, que é formado em turismo e hoje possui um empreendimento na localidade (mas não na área de turismo), o senhor Tiago.

Com o senhor Wilmar, ocorreu uma entrevista com algumas perguntas chaves para poder entender melhor qual é a atual situação do turismo na localidade. Segundo ele Formosa possui recursos para que o turismo se desenvolva, mas ainda não houve a oportunidade para que fosse elaborado um plano ou mesmo um projeto para fomentar o turismo na região. Existe sim uma exploração na localidade, mas é pouca, e as condições são muitas.

"Existe uma parceria com o Instituto Interamericano de Cooperação para a Agricultura - IICA e dessa parceria surgiram quatro projetos que estão em andamento no município, projetos que podem no futuro ser ligados ao turismo". A Secretaria de Turismo foi extinta e até o momento dessa entrevista, não havia ainda definido com quem ficariam suas funções. "A maior dificuldade para tornar o turismo uma atividade que promova o município, está na falta de interesse e incentivo por parte do governo local, no caso a prefeitura", mas o senhor Wilmar acredita que "com um bom projeto para a localidade essa situação pode mudar rapidamente".

"Para que um projeto de turismo se desenvolva é preciso primeiramente a busca da interação da comunidade, sendo assim para um projeto ser desenvolvido em Formosa o senhor Wilmar afirma que a comunidade local será envolvida impreterivelmente".

Segundo o secretário, "o que Formosa precisa é de alguém que enxergue o turismo como uma atividade que tornará o município mais próspero, que realmente veja a localidade como ela é: um grande potencial turístico".

A segunda entrevista foi com o Senhor Secretário da Agricultura, Pecuária e Meio Ambiente $\mathrm{Dr}^{\circ}$ Valdir. Ele acredita que "o turismo trará maiores divisas para a região, 
pois Formosa possui um potencial extraordinário, ainda não utilizado". Mas falta infra-estrutura básica e turística, incentivos por parte do governo, e principalmente divulgação da localidade. Vê ainda que, "por meio de parcerias com órgãos públicos e privados o turismo pode se tornar uma atividade altamente rentável para a região".

A sede da secretaria de Agricultura, pecuária e Meio Ambiente fica na Mata da Bica, que é um Parque Ecológico, localizado na zona central do município de Formosa. Nele encontram-se nascentes de um dos rios que formam a Bacia Hidrográfica do Rio São Francisco, mas infelizmente estas nascentes estão poluídas e o parque não é bem cuidado. O senhor Valdir acredita que, "com uma fiscalização mais rígida e incentivos para a melhoria da situação atual do parque, este pode ser aberto para a comunidade e para visitantes". Afinal são, 25,68 hectares de mata nativa do cerrado brasileiro.

Após essas entrevistas, a visita foi ao prédio "Itiquira", que está localizado no centro da cidade, bem próximo à secretaria de Desenvolvimento Econômico. $O$ representante agora é o promotor público o Dro Frederico. Segundo ele, "Formosa realmente tem muitas belezas naturais, e um bom potencial, mas essa "cultura do barulho" pode gerar um problema para o turismo na localidade, ou piorar ainda mais a situação da cidade, pois a maioria dos eventos que acontecem, são festas muito barulhentas". Ele acredita que o turista quando procura atrativos naturais em uma localidade, quer dizer que quer paz e tranqüilidade e com essa chamada "cultura do barulho", para atrair turistas para a localidade será necessária uma divulgação muito grande, mas principalmente, "a criação de um tema chamativo (uma marca para a localidade)". Mas mesmo assim acharia ótimo o aumento de turistas na localidade, pois assim a economia local aumentará.

A entrevista com o senhor Tião da Celg foi bem rápida, e ele respondeu a um questionário já elaborado anteriormente. Também segundo ele "Formosa tem um potencial turístico muito grande, porém ainda não divulgado, falta informação para os proprietários das terras onde estão alguns atrativos, sobre sua grande potencialidade". Ele acredita que para que o turismo se desenvolva "é preciso buscar parcerias, com governo e iniciativa privada". Vê a Festa do Divino como um atrativo cultural de enorme potencial, por ser uma das maiores do estado do Goiás. E ainda diz: "desde que o município tenha condições de atender os turistas o aumento do número de turistas na localidade seria ótimo". 
A última entrevista foi com o senhor Tiago. Foi interessante e bem produtivo conversar com ele, primeiro por ser um representante do comércio local, mas por ele também ser formado em turismo, o que tornou a entrevista muito importante. Apesar de não atuar na área, como turismólogo, sua visão da situação da localidade se torna talvez um pouco mais crítica. Mas apesar dessa diferença, suas respostas chegaram bem perto das que foram relatadas anteriormente. "Formosa é um município com grande potencial, porém faltam incentivos e divulgação da localidade; - governo está desinteressado e a infra-estrutura local e turística está desatualizada".

Uma questão levantada nessa conversa, que diferenciou um pouco das outras entrevistas, foi a de integração com cidades vizinhas, cidades que já possuem um demanda turística maior do que a de Formosa, buscando a idéia de roteiros integrados. Idéia essa que já faz parte das linhas gerais que estão nas propostas finais deste projeto.

No dia 31 de março de 2008 foi realizada a última visita após a informação do senhor Wilmar de que tinha sido definido o secretário que ficaria responsável pelas questões do turismo na região. Assim para que o diagnóstico das entrevistas pudesse ser finalizado viu-se a necessidade de conversar também com o Senhor Leônidas da Silva Pires Secretário de cultura até então e agora de turismo também.

A entrevista seguiu um roteiro pré-elaborado, o mesmo utilizado na conversa com o senhor Wilmar e por meio deste as seguintes respostas e proposições foram feitas por parte do Sr. Leônidas.

"O turismo tem um papel fundamental no município, tendo em vista que o forte da localidade, além da pecuária e agricultura é o turismo. Mas está faltando fomentar está questão, desenvolver internamente num primeiro plano, pois não adianta nada buscar um mercado mais amplo da forma como a cidade e o município estão".

O senhor Leônidas acredita que o turismo pode ser desenvolvido sim na cidade e no município de Formosa, trazendo mais turistas, para maior geração de empregos, maior renda e divisas para a população e a localidade respectivamente. Segundo ele isso deve ser feito por meio da "estruturação com organização interna, inclusão dos agentes ligados ao turismo (hotelaria e restaurantes) e educação da comunidade local". 
Quando perguntado se existe um plano de desenvolvimento turístico para a região a resposta do senhor Leônidas foi a seguinte: "para que o turismo comece a andar é preciso traçar um plano turístico, onde envolva o poder público, comunidade, e agentes do turismo".

O senhor Leônidas está assumindo agora a parte de turismo e segundo ele, ainda está buscando, junto aos outros representantes, meios para desenvolver este plano. Por meio de pesquisas com empreendedores da região, busca saber a melhor maneira de tornar a cidade uma localidade turística.

A pergunta agora é a respeito do comportamento do turista e o senhor Leônidas acredita que "o comportamento do turista aqui em Formosa ainda é muito tímido, não existe uma interação entre turista e moradores locais de fato". O maior causador deste fator é que: a maioria dos turistas que vão para Formosa, seguem seu caminho direto para o salto do Itiquira e para chegar lá, é só atravessar a rua principal da cidade, ela corta Formosa de uma ponta a outra, assim do mesmo jeito que o turista entra ele sai de Formosa sem nem mesmo ver o que a cidade tem.

Para o secretário, o CAT poderia ter sido feito dentro da cidade, "próximo a rodoviária, por exemplo, ali o aproveitamento seria maior". E já que o assunto é o CAT, foi perguntado a ele o porquê de estar fechado nos últimos meses. Segundo o secretário, o CAT está sendo reformado para poder ser reativado. "Por conta das chuvas fortes ocorreram infiltrações e por ter sido abandonado a fiação do local foi roubada, mas agora está passando por uma reforma e assim que o posto policial voltar a funcionar, pois também estava desativado o CAT retoma suas atividades".

Ainda diz: "é um perigo muito grande nós colocarmos pessoas para trabalhar lá no CAT sem que tenha segurança, sem a presença da policia militar, e por conta disso o comandante da polícia o Major Ricardo Rocha, reativou o posto policial com o compromisso de que a prefeitura faria o mesmo com o CAT, se o CAT fosse mais centralizado não teria este problema de desativação por falta de segurança".

A respeito da maior dificuldade segundo ele para implementar o turismo na região seria "conscientizar a população de que o município tem um grande potencial e que o turismo traz divisas imediatas. A cidade precisa ainda da construção de um pólo turístico, um centro de cultura e turismo, para bem receber o turista, para os artesões terem um espaço; um centro com barzinhos, uma concha acústica para 
captar eventos, mas o governo não pode tomar essa decisão sem antes consultar a comunidade e os próprios agentes envolvidos com o turismo na região".

A medida inicial seria apresentá-los como secretaria de turismo para a sociedade e depois apresentar um plano com metas e objetivos, mostrando como será feito, como a sociedade será incluída e que para acontecer da melhor maneira possível ela precisa cumprir o seu papel que é o ponto mais importante na visão do secretário.

Quando foi falado da falta de incentivos, que a maioria dos representantes da comunidade marcou essa opção na pesquisa feita o secretário disse o seguinte: "a falta de incentivos existe, porque o turismo é uma cadeia produtiva, onde, João depende de Maria que depende de José e enquanto estes não estiverem falando a mesma língua não vai funcionar. Então se a falta de incentivos existe, existe, por parte do município, do governo local, da União, mas existe porque nós como sociedade ainda não nos mobilizamos, não estamos organizados, com cada um fazendo sua parte, para definir o que precisa ser feito e organizado".

O secretário finaliza a entrevista dizendo que, a idéia chave para que o turismo se desenvolva de verdade é que desde o começo da proposta para a elaboração do plano de desenvolvimento econômico e turístico, a questão da inclusão da comunidade sempre foi trabalhada como primordial e trabalhando inicialmente a parte interna, para expandir depois o município entra com força total, se mostrando um grande pólo receptor de turistas. 


\section{3 - Pesquisas com Proprietários}

A pesquisa com os proprietários não foi muito ampla por conta da dificuldade de entrar em contato com os mesmos. Devido a esse entrave, foram realizadas duas pesquisas já pré-elaboradas.

A primeira foi com o senhor José Carlos, arrendatário do Parque Ecológico do Itiquira e um dos representantes da Estância do Itiquira, os dois pertencem ao complexo do Itiquira, principal atrativo visitado em Formosa. De acordo com o questionário foi constatado que: o senhor José Carlos tem o interesse em aumentar sim o número de visitantes que hoje freqüentam o local, quanto a ações de sustentabilidade feitas no local são só ações de conservação do meio ambiente. Ele emprega 35 pessoas e todas são da região com os mais diferenciados níveis de escolaridade, depende do cargo que a pessoa está executando. Quanto aos cursos de qualificação e capacitação, o próprio empreendimento oferece aos seus funcionários, levando palestrantes ao local.

A segunda foi com o senhor Ivo, dono do Hotel Fazenda Araras, que está localizado nas terras onde se encontra o Buraco das Araras. Segundo ele a divulgação do hotel já ocorre por meio de flyers, Internet, panfletos distribuídos em Formosa e região, para poder aumentar o número de turistas em seu empreendimento. Lá no hotel eles tomam medidas quanto a economia de água e luz, fazer coleta seletiva e executam ações de conservação do meio ambiente por meio de placas de conscientização. Possuem 33 funcionários, destes 22 são da região e o nível de escolaridade deles é muito baixo, a maioria só tem o primário e tem até analfabetos, mas apesar disso ele oferece aos seus funcionários cursos de qualificação e capacitação do SENAC e SEBRAE local.

Um terceiro atrativo já bastante conhecido no município é a cachoeira do Indaiá, mas foi difícil o contato com este atrativo não sendo possível ser feita a pesquisa.

Quanto aos demais atrativos naturais, segundo informações, os proprietários não possuem nenhum tipo de empreendimento no local e o máximo que fazem é cobrar um valor simbólico para que os visitantes possam entrar em suas terras e usufruir o atrativo que ali existe. 


\section{4 - Pesquisa com Coordenadores dos Programas Sociais}

A pesquisa que será detalhada neste tópico, trás um questionário com perguntas diretas, feitas com coordenadores dos programas e projetos desenvolvidos pela prefeitura de Formosa por meio da Secretaria de Trabalho e Promoção Social. A pesquisa trás um universo de 11 representantes de um total de 12 programas desenvolvidos, segundo o site da prefeitura local.

Os resultados encontrados foram os seguintes:

\begin{tabular}{|c|c|c|c|c|c|c|c|c|c|c|c|c|}
\hline $\begin{array}{l}1 \text { - Você acha que o Turismo traz recursos para a } \\
\text { Comunidade? Porque? }\end{array}$ & 1 & 2 & 3 & 4 & 5 & 6 & 7 & 8 & 9 & 10 & 11 & Total \\
\hline ( ) Sim & $x$ & $x$ & $x$ & $x$ & $x$ & $x$ & $x$ & $x$ & $x$ & $x$ & $x$ & 11 \\
\hline ( ) Não & & & & & & & & & & & & 0 \\
\hline
\end{tabular}

Como demonstrado na tabela acima, $100 \%$ da amostra acredita no turismo com gerador de recursos e as respostas que mais se repetiram quando perguntado o porquê, foram: geração de empregos e maior movimentação do comércio local.

\begin{tabular}{|c|c|c|c|c|c|c|c|c|c|c|c|c|}
\hline $\begin{array}{l}2 \text { - Você acha que o município tem potencial para ter o } \\
\text { Turismo como uma atividade que possa trazer } \\
\text { benefícios tanto para a sociedade e também para os } \\
\text { empresários? }\end{array}$ & 1 & 2 & 3 & 4 & 5 & 6 & 7 & 8 & 9 & 10 & 11 & Total \\
\hline ( ) Sim & $x$ & $x$ & $\mathrm{x}$ & $x$ & $x$ & & $x$ & $x$ & $x$ & $x$ & $x$ & 10 \\
\hline ( ) Não & & & & & & $x$ & & & & & & 1 \\
\hline
\end{tabular}

Aqui apenas um representante respondeu que não, explicando que por conta da falta de infra-estrutura ainda não se pode dizer que o município tem realmente potencial para que o turismo possa acontecer e assim trazer benefícios.

\begin{tabular}{|c|c|c|c|c|c|c|c|c|c|c|c|c|}
\hline $\begin{array}{l}3 \text { - Para você qual desses fatores impede que o } \\
\text { Turismo se desenvolva no Município? }\end{array}$ & 1 & 2 & 3 & 4 & 5 & 6 & 7 & 8 & 9 & 10 & 11 & Total \\
\hline ( ) Infra-estrutura básica e turística desatualizada & & $\mathrm{x}$ & & & & $\mathrm{x}$ & $x$ & $\mathrm{x}$ & $\mathrm{x}$ & & & 5 \\
\hline ( ) Governo local desinteressado & & & $x$ & & $x$ & $x$ & $\mathrm{x}$ & $\mathrm{x}$ & & & $\mathrm{x}$ & 6 \\
\hline ( ) Proprietários desinformados & & $\mathrm{x}$ & & & & $\mathrm{x}$ & & $x$ & $\mathrm{x}$ & & & 4 \\
\hline ( ) Falta de Incentivos & $\mathrm{x}$ & $\mathrm{x}$ & $\mathrm{x}$ & & & $x$ & & $\mathrm{x}$ & $\mathrm{x}$ & $x$ & $\mathrm{x}$ & 8 \\
\hline ( ) Falta de divulgação dos atrativos locais & $\mathrm{x}$ & $\mathrm{x}$ & $\mathrm{x}$ & & & $x$ & $\mathrm{x}$ & $\mathrm{x}$ & $x$ & & & 7 \\
\hline ( ) Falta de Interesse Comunidade & $\mathrm{x}$ & $x$ & & $x$ & & $x$ & & $\mathrm{x}$ & & $x$ & $\mathrm{x}$ & 7 \\
\hline
\end{tabular}

Nesta questão cada item é analisado separadamente, pois cada participante teve o direito de escolher mais de um fator. Como representado na pergunta, com 72,70\% a falta de incentivos (por parte do governo municipal, estadual e federal) foi o mais assinalado, seguido pela falta de interesse da comunidade e falta de divulgação dos atrativos locais cada um com $63,60 \%$. Sendo assim, a comunidade acredita que: 
como está hoje Formosa não possui condições de se tornar uma localidade onde o turismo possa acontecer da melhor maneira possível, faltam os fatores que são primordiais.

\begin{tabular}{|c|c|c|c|c|c|c|c|c|c|c|}
\hline 4 - Você incentivaria o Turismo? Se sim, como? & 1 & 23 & 4 & & 67 & 8 & 9 & 10 & 11 & Total \\
\hline ( ) Sim & $\mathrm{x}$ & $x \mathrm{x}$ & $x$ & & $x$ & $\underline{x}$ & $x$ & $\mathrm{x}$ & $x$ & 11 \\
\hline ( ) Não & & & & & & & & & & 0 \\
\hline
\end{tabular}

Quando o assunto é incentivo ao turismo, apesar de na questão anterior a maioria citar a falta de interesse da comunidade, estes como representantes da própria comunidade em sua totalidade disseram que incentivariam sim o turismo, e as principais respostas dadas quando perguntado como fariam isso foram: divulgando, convidando as pessoas, valorizando a cidade e seus atrativos, incentivando a sociedade a conhecer pelo menos os principais atrativos. Vê-se aqui nesta questão, que idéias existem, mas a comunidade ainda não encontrou formas de executá-las.

$\mathrm{Na} 5^{\mathrm{a}}$ questão foi perguntado de forma aberta, o que é turismo sustentável? O resultado foi: algumas pessoas não souberam responder, outros não responderam com exatidão, confundindo um pouco com a idéia de investimento, incentivos governamentais, não explicando exatamente como isso ajudaria na questão do turismo sustentável. Dos 11 questionários aplicados apenas três chegaram bem perto do que de fato é um turismo sustentável, e as respostas foram as seguintes:

"É um desenvolvimento sustentável que satisfaz as necessidades dos turistas atuais, das regiões receptoras enquanto protege e aumenta as oportunidades para o futuro". (representante do programa Agente Jovem).

"É O que promove a aproximação do ser humano como a natureza sem a degradação do meio ambiente, ele busca não causar maiores impactos nessa aproximação". (representante do programa Morrer com Dignidade).

"Ė o turismo que visa minimizar impactos ecológicos e sócio-culturais, enquanto promove benefícios econômicos para a comunidade". (representante do programa Agente Jovem)". 


\begin{tabular}{|c|c|c|c|c|c|c|c|c|c|c|c|c|}
\hline 6 - Quais desses atrativos naturais você conhece? & 1 & 2 & 3 & 4 & 5 & 6 & 7 & 8 & 9 & 10 & 11 & Total \\
\hline ( ) Salto do Itiquira & $x$ & $x$ & $x$ & $x$ & $x$ & $x$ & $x$ & $x$ & $x$ & $x$ & $x$ & 11 \\
\hline ( ) Cachoeiras do Indaiá & $\mathrm{x}$ & $x$ & $x$ & $x$ & $x$ & $x$ & $x$ & & $x$ & $x$ & $x$ & 10 \\
\hline ( ) Buraco das Araras & $\mathrm{x}$ & & & & $x$ & & $x$ & & & & $x$ & 4 \\
\hline ( ) Gruta das Andorinhas & & & & & & & $\mathrm{x}$ & & & & $x$ & 2 \\
\hline ( ) Cachoeira da Capetinga & & & & & & & & & & & & 0 \\
\hline ( ) Cachoeiras do Bandeirinha & & & $x$ & & & & & & $x$ & $x$ & $x$ & 4 \\
\hline ( ) Lajedo & & & & & & & $x$ & & & & $x$ & 2 \\
\hline ( ) Pedreira Toca da Onça & & & $x$ & & $x$ & & & & & & $\mathrm{x}$ & 3 \\
\hline ( ) Sítios Arqueológicos & & & & & & & & & & & $x$ & 1 \\
\hline ( ) Mata da Bica & $x$ & $x$ & $x$ & $x$ & $x$ & $x$ & $x$ & $x$ & $x$ & $x$ & $x$ & 11 \\
\hline ( ) Lagoa Feia & $x$ & $x$ & $x$ & $x$ & $x$ & $x$ & $x$ & $x$ & $x$ & $x$ & $x$ & 11 \\
\hline ( ) Lago do Vovô & $x$ & $x$ & $x$ & $x$ & $x$ & $x$ & $x$ & $x$ & & $x$ & $\mathrm{x}$ & 10 \\
\hline ( ) Trilha do Sino & & & & & & & & & & & & 0 \\
\hline
\end{tabular}

Essa questão foi elaborada após o levantamento dos atrativos e potenciais turísticos de Formosa (citado no capítulo III), para ver se os representantes da comunidade que responderam ao questionário realmente conhecem o que seu município pode oferecer para o turista. Os resultados foram: $90,90 \%$ a $100 \%$ conhece os principais atrativos, os que já possuem certa infra-estrutura e recebe turistas, Salto do Itiquira, Cachoeira do Indaiá, bem como os que estão localizados dentro da cidade de Formosa que são: Mata da bica, Lagoa Feia e Lago do vovô. Já para o Buraco das Araras, um atrativo bastante visitado pelos turistas, principalmente os que se hospedam no hotel fazenda araras, apenas $36,40 \%$ disseram conhecer. Os demais obtiveram uma porcentagem bem baixa e os que assinalaram, explicaram que conheceram o local quando criança e há muito tempo não o visitavam mais.

A $7^{\text {a }}$ questão foi elaborada com o mesmo intuito da anterior, mas agora em forma de questão aberta, procurando saber a respeito dos atrativos culturais da cidade. Os principais atrativos e potenciais citados foram: Museu couros, as festas religiosas em geral, mas principalmente a festa do Divino Espírito Santo, festa da Moagem, grupos de dança típica e o teatro, que segundo a senhora Joana do programa de Atenção Integral a Família, recentemente tiveram algumas apresentações no local. 


\begin{tabular}{|l|l|l|l|l|l|l|l|l|l|l|l|l|}
\hline $\begin{array}{l}\text { 8 - O que você acharia do aumento do número de } \\
\text { turistas na cidade? Porque? }\end{array}$ & $\mathbf{1}$ & $\mathbf{2}$ & $\mathbf{3}$ & $\mathbf{4}$ & $\mathbf{5}$ & $\mathbf{6}$ & $\mathbf{7}$ & $\mathbf{8}$ & $\mathbf{9}$ & $\mathbf{1 0}$ & $\mathbf{1 1}$ & Total \\
\hline ( ) Ótimo & & $\mathrm{x}$ & & $\mathrm{x}$ & $\mathrm{x}$ & $\mathrm{x}$ & $\mathrm{x}$ & & $\mathrm{x}$ & & $\mathrm{x}$ & 7 \\
\hline ( ) Bom & $\mathrm{x}$ & $\mathrm{x}$ & & & & $\mathrm{x}$ & & $\mathrm{x}$ & & 4 \\
\hline ( ) Regular & & & & & & & & & & & 0 \\
\hline ( ) Ruim & & & & & & & & & & 0 \\
\hline ( ) Não Sei & & & & & & & & & & 0 \\
\hline
\end{tabular}

A questão acima demonstra que a comunidade está sim aberta para a entrada do turismo com meio para o desenvolvimento da região. $63,60 \%$ acharia ótimo e $36,40 \%$ bom. No ponto de vista deles, o turismo trará, maiores divisas, mais empregos, inclusão social, integração cultural para a cidade e o município em geral.

\section{5 - Análise dos Atrativos Naturais}

A infra-estrutura de apoio em boa parte dos atrativos é inexistente ou inadequada, gerando dificuldades ao acesso e utilização, bem como tornando muitos potenciais pouco adequados à visitação. Como exemplo tem: o Lajedo, Buraco das Araras e Gruta das Andorinhas. Nestes locais não existe uma boa infra-estrutura de acesso, sinalização adequada, pontos de apoio ao turista, com alimentação, banheiros e outros.

Nos atrativos naturais não foi encontrado nenhum tipo de acessibilidade a portadores de necessidades especiais. Mesmo no atrativo que possui uma certa infra-estrutura, Salto do Itiquira, não se encontra acesso adequado como rampas, corrimãos, pisos mais apropriados que facilitem a entrada dos portadores de necessidades especiais.

Existe sinalização adequada para se chegar aos atrativos, porém, não há uma sinalização interpretativa e informativa especificamente dentro deles, acarretado pelo descaso dos proprietários, e assim culminando na falta de integração entre poder público e privado. Como resultado, os atrativos não transmitem a idéia de conservação de patrimônio natural e cultural, bem como educação ambiental em prol de um desenvolvimento sustentável.

\section{6 - Análise SWOT das Potencialidades Turísticas}

Esta analise tem o intuito de estudar o macroambiente como um todo. Determinando os pontos fortes, fracos, oportunidades e ameaças. Pontos fortes e fracos representam um estudo da parte interna da organização, objeto ou meio em 
questão. Na analise das oportunidades e ameaças tem-se a visão externa do ambiente estudado.

Partido deste contexto explicado por Wright (2000), segue a analise SWOT do município de Formosa na visão da autora deste projeto.

Pontos Fortes

- Local de grandes belezas naturais;

- Fácil acesso aos principais atrativos;

- Cultura carregada de tradição;

- Comunidade receptiva; turístico

- Existência de verba para a realização de um plano de desenvolvimento Pontos Fracos

- Falta de infra-estrutura turística nos atrativos naturais;

- Ausência de incentivos da prefeitura local;

- Inexistência de um plano de desenvolvimento turístico;

- Falta de profissionais capacitados para conduzir os turistas nas trilhas;

- Falta de mão-de-obra qualificada;

- Falta de infra-estrutura hoteleira;

Oportunidades

- Integração com outras localidades / Roteiros integrados;

- Aumento no número de empregos;

- Aumento no número de visitantes;

- Maior divulgação do município e da cidade;

- Desenvolvimento sociocultural;

Ameaças

- Localidades próximas com o turismo mais desenvolvido;

- Epidemias;

- Mudança de governo (projeto previsto para médio a longo prazo);

- Descuido com os atrativos naturais; 


\section{VI - PROGNÓSTICO}

A partir do capítulo anterior, as idéias que seguem agora, são propostas a serem analisadas para a implementação de um plano de desenvolvimento turístico para a região. Todo o conteúdo descrito nessa parte do projeto poderá se tornar em medidas a serem tomadas por interessados em aumentar o fluxo de turistas em Formosa, por meio dos princípios da sustentabilidade.

Os principais pontos analisados nesse capítulo são os pontos fracos da localidade, e assim após a análise feita no capítulo anterior, neste será explicado como devem ser otimizados. Trará também, as questões levantadas nas pesquisas, apontadas como negativas para o município.

\section{1 - Melhorias na Infra-estrutura Básica e dos Atrativos Naturais}

Como citado no capitulo anterior, um ponto a ser maximizado é a infra-estrutura básica e de apoio, tanto da cidade de Formosa, quanto nos atrativos.

Nos atrativos naturais o que se deve procurar é a melhor maneira de transformá-los sem a degradação do meio ambiente onde estão localizados. Fazer com que as trilhas e os acessos sejam mais fáceis, diminuindo em vezes o grau de dificuldade de várias delas e em outras trazendo maior segurança para o turista, lembrando que isso precisa ser feito seguindo alguns dos conceitos citados anteriormente, de sustentabilidade. Como por exemplo: pontos de apoio ao turista com banheiros, locais para alimentação e descanso, sendo construídos de forma que minimizem os impactos ao meio ambiente. Em alguns atrativos isso se faz necessário, mas na grande maioria que são cachoeiras, trilhas, e sítios arqueológicos, o ideal é não perturbar muito a harmonia do local.

Nas trilhas, propõe-se, uma seqüência de placas explicativas, tanto no ponto de vista de direção, tamanho, nível de perigo e dificuldade, como também com indicações do tipo de fauna e flora que é encontrada no local, mas principalmente informações de conservação do local, placas educativas e informativas. 


\section{2 - Promoção e Divulgação da Localidade}

Nesta parte do prognóstico a sugestão é que se crie um plano de marketing especifico para Formosa, que deve seguir conceitos que serão dispostos na configuração do mix de marketing (Preço, Praça, Produto e Promoção).

$>$ Preço:

O preço no contexto para este projeto é o de entrada dos atrativos. Hoje o que acontece em Formosa é que cada proprietário das terras onde estão os atrativos firma o preço que seja interessante no seu ponto de vista. Seria interessante formatar um padrão, para que os turistas pudessem visitar todo os atrativos, sem por vezes escolher algum pelo preço mais em conta, desta forma os atrativos antes menos visitados, poderão vir a ser também usufruído pelos visitantes.

Assim todos saem ganhando, tanto o turista que poderá usufruir e conhecer vários locais de beleza rara, como também os proprietários, que terão maiores lucros.

$>$ Praça:

Entende - se praça como meios de distribuição, por meio de ações nesse contexto que o turismo poderá ser bem desenvolvido no município e na cidade.

Para que isso aconteça sugere-se aqui uma melhor utilização do próprio site da prefeitura de Formosa, onde já existe informação sobre os atrativos mais conhecidos, mas pode ser trabalhada mais amplamente. A partir daí, talvez criar um site especifico para uma divulgação mais intensa dos atrativos locais.

Se a sociedade entender melhor o que o turismo pode trazer para a região e para a própria população, poderá também divulgar com o chamado, "boca-a-boca" e transformar o município em um grande receptor de turistas.

A própria mídia (TV, rádio, jornais, revistas e internet), pode ser uma grande aliada na busca do desenvolvimento local por meio do turismo. Com a criação de uma imagem turística, que poderá se tornar a marca da cidade, Formosa tem tudo para transformar as potencialidades hoje conhecidas, em grandes atrativos turísticos.

Propõe-se também a criação de um programa de filiação com agências de viagem da própria cidade, mas também de localidades de onde chegam a maior parte dos turistas do município. Com esse programa, Formosa terá mais pontos de distribuição 
de seus produtos, podendo aumentar consideravelmente o número de turistas na região.

$>$ Produto:

Os produtos que são oferecidos em Formosa são os atrativos, tanto naturais como culturais, que são: Salto do Itiquira, Cachoeiras do Indaiá, Buraco das Araras, Gruta das Andorinhas, Cachoeira da Capetinga, Cachoeiras do Bandeirinha, Lajedo, Pedreira Toca da Onça, Sítios Arqueológicos, Mata da Bica, Lagoa Feia, Lago do Vovô, Berço das Águas do Brasil, Trilha do Sino, Museu de Arte Cultura e Tradição, Exposição Agropecuária, além dos vários eventos que acontecem no município.

Para que sejam desenvolvidos, propõe-se o levantamento mais conciso da atual situação de cada um, para que juntamente com os proprietários possa ser feito um plano de adequação mais apropriada para cada atrativo. Aqui cabe destacar também a necessidade de um projeto de capacidade de carga, para que o número de visitantes não exceda seu poder e absorção pelos atrativos.

A respeito dos atrativos culturais, seria interessante a divulgação por parte dos órgãos governamentais responsáveis. Como conseqüência disso sua manutenção e conservação, para que futuros visitantes possam ter a mesma sensação de conhecer a história do município, e principalmente, para que os artefatos e a cultura não se percam no caminho.

$>$ Promoção:

Sugere-se aqui a criação de um slogan que mostre o que realmente é Formosa. Além desse ponto, é interessante que a divulgação seja maior em outros estados. Hoje a maior divulgação de alguns atrativos é em Goiânia, principalmente do itiquira.

Posteriormente será abordada a questão dos roteiros integrados. Observa-se a necessidade de vincular a propaganda que hoje é exibida em algumas localidades do estado de Goiás, aos municípios e cidades próximas a Formosa, para maior captação de recursos.

Além disto, a formatação de uma imagem turística, associadas aos seus potenciais e diferenciais seria um reforço para esta ação. Um exemplo já existente em outra localidade muito visitada é o Cristo Redentor que é a imagem mais diretamente associada ao destino Rio de Janeiro. Essas imagens são capazes de colaborar com 
a divulgação do município nos segmentos de interesse, seja por meio de um slogan, que apresenta em poucas palavras uma identidade do local. Ou pelo recurso da logomarca ${ }^{10}$ que mostra os principais atributos e características ligadas a uma imagem marcante e única. Além de outros recursos utilizados pelo marketing.

\section{3 - Qualificação e Capacitação da Mão-de-obra}

Elaboração de projetos que visam captar recursos federais para implementação de capacitação de pessoal, que trabalhará diretamente com a atividade turística. Essa capacitação deverá atingir todos os níveis de serviços oferecidos, dando ênfase ao melhoramento dos serviços prestados pela população menos favorecida. Sempre a capacitação visará a excelência e a padronização de atendimento e prestação de serviços, para assim atender e superar as expectativas, desejos e necessidades dos visitantes.

Reabertura do Centro de Atendimento ao Turista - CAT, com profissionais da área e capacitados para oferecer ao turista a melhor informação, para que não haja dúvidas quanto à situação dos atrativos, bem como sua localização. Neste centro a prioridade deverá ser a captação do máximo de informações turísticas, culturais e sociais, para que o turista antes de conhecer o atrativo já se sinta atraído por ele, por meio de sua história.

Assim além de se tornar o passeio mais produtivo, fará o turista conhecer a cultura e a história da cidade e de seus principais locais de visitação. Isso trará a integração entre cidadão local e visitante, podendo se tornar uma relação que possa vir a acrescentar muito para os dois lados.

Seria interessante a criação de um projeto que auxilie os guias de turismo que hoje, mesmo sem qualificação, fazem as trilhas com turistas, proporcionando a eles um maior aproveitamento quanto a diversidade na localidade, com noções de respeito ambiental, cidadania, conhecimento maior da fauna e flora, isso poderá enriquecer o passeio, tornando mais atrativo e produtivo tanto para os turistas, como também para os guias, que terão maior credibilidade em seu trabalho.

\footnotetext{
${ }^{10}$ Símbolo gráfico que conjuga o nome do produto, ou seja, sua marca, com um modo especial de apresentação. DOLABELA, Fernando. O Segredo de Luísa, São Paulo: Cultura Editores Associados, 1999. p. 189.
} 


\section{4 - Parcerias}

Tendo em vista a existência de verbas governamentais para o setor do turismo no município de Formosa, segundo informação do senhor Wilmar, secretário de Desenvolvimento Econômico, deve-se buscar aumentar a integração e parcerias entre o poder público e privado, tendo em vista melhorias na infra-estrutura geral dos atrativos, com intuito de minimizar os problemas de acesso das propriedades onde estão localizados os potenciais turísticos, que em sua maioria são propriedades particulares.

Essa ação pode ainda proporcionar maior facilidade ao município no sentido de trazer maiores recursos (investimentos), visando se adequar nas melhorias na área de segurança pública, aumentando o efetivo tanto em recursos humanos quanto em equipamentos, principalmente na zona urbana e nas áreas com potencial turístico.

Uma outra parceria interessante seria para cursos de formação, seminários, oficinas e cursos técnicos que tenham reconhecimento. Estas seriam parcerias que poderiam prover certificação reconhecida no meio do turismo a nível regional, federal e internacional. Essas certificações poderão trazer credibilidade para a atividade turística do município no quesito de prestação de serviços. Isso implementará o fluxo turístico e a movimentação de renda interna, além de aumentar o nível educacional e cultural da população local.

\section{5 - Inclusão da Comunidade local}

Outro fator muito relevante é a inclusão da comunidade local no projeto. A realidade é que de nada adianta, fazer todo um plano de desenvolvimento turístico, se a sociedade local não estiver receptiva para o turismo. A idéia inicial é a elaboração de panfletos educativos, para que os moradores locais possam saber quais atrativos existem (pois segundo as pesquisas feitas pela autora, muitos dos habitantes locais não conhecem alguns dos atrativos de Formosa), como tratar o turista para que ele se sinta bem, goste e divulgue a localidade, como também incentivos para que o artesanato local possa ser mais divulgado, incluindo a sociedade também na receita gerada pelo turismo no município.

Dentro dessa inclusão deve-se trabalhar com a parcela da população menos favorecida, artesãos que estão procurando meios para divulgar e vender seus trabalhos, oferecendo não só cursos de qualificação para estes, mas também de 
capacitação para os que precisam trabalhar, mas ainda não encontraram um meio para fazer isso.

\section{6 - Roteiros Integrados}

O Plano também deve abordar a criação de roteiros integrados, que de acordo com a filosofia do Ministério do Turismo, por meio do Programa de Regionalização, essa idéia é capaz de proporcionar um grande aumento na geração de renda e emprego por meio de sua estruturação, que colaborarão marcantemente no aumento do tempo de permanência dos visitantes. Assim se faz pertinente a proposta de criação de roteiros integrados dentro e fora do município, fazendo com que aumente 0 período de permanência do turista e, por conseqüência, aumentando a receita do município.

No ponto de vista de fora do município propõe-se roteiros de cidades entre Brasília e o município de Formosa. De Brasília sairiam empresários que estão na cidade a negócio e nos fins de semana livres podem aproveitar a viagem para conhecer os atrativos turísticos de Formosa e região. Pode-se também criar roteiros entre Formosa e Chapada dos Veadeiros, Alto Paraíso dentre outras localidades que fazem parte da conhecida Estrada Real.

Mas quando o assunto é um roteiro interno, a proposta deste projeto é a criação de um roteiro onde o turista que vai a localidade passar o fim de semana, possa conhecer seus principais atrativos naturais levando mais divisas para hotéis, restaurantes e parques. Um exemplo seria uma parceria entre os proprietários desses principais atrativos formando um roteiro entre, Itiquira, Buraco das Araras, Gruta das Andorinhas. E para que isso aconteça da melhor maneira o ideal seria a criação de um voucher único para fazer todo esse passeio.

O visitante chegaria diretamente ao parque do Itiquira e passaria a manhã no local, de lá ele é levado para um almoço dentro da cidade, após o almoço ele conhece o museu, as praças e os atrativos internos, lago do vovô, mata da bica, o hotel fazenda araras, onde chegando lá é levado para o passeio no buraco das araras, retornando ao hotel para dormir e no dia seguinte após o café da manhã, faz a trilha da gruta das andorinhas, volta ao hotel, almoça e retorna a sua cidade. 


\section{VII - CONSIDERAÇÕES FINAIS}

Tendo em vista todos os fatores analisados neste trabalho e diante de todas as proposições feitas, conclui-se que:

O turismo em Formosa pode ser desenvolvido de forma sustentável, levando à comunidade uma maior qualidade de vida e rendimentos mensais. Trabalhando primeiramente a sociedade local, divulgando internamente, incentivando-os a apreciar as belezas naturais do local, a conhecer os muitos atrativos que existem lá. Tudo isso pode levar a uma maior aceitação por parte dos moradores, de que o turismo é uma atividade que pode realmente trazer muitos benefícios.

Com um maior entendimento de que a atividade turística é benéfica para todos, e enxergando o imenso potencial que Formosa tem, por meio de conversas e convites, a própria sociedade estará fazendo a divulgação do município, passando sua cultura para o mais variado público e assim difundindo Formosa como um grande pólo turístico do estado do Goiás.

Mas para que isso aconteça é importante que medidas sejam tomadas, algumas mais rápidas, outras a médio e longo prazo. Medidas rápidas como a atualização e manutenção da infra-estrutura básica, são essenciais para o bom andamento do projeto de desenvolvimento do turismo. Criação de conscientização e de programas que tragam a participação da sociedade na atividade.

A médio prazo, deve-se citar a criação de um plano para melhorar a infra-estrutura hoteleira e de restaurantes, para assim atender melhor o turista, que prefere passar um fim de semana, ou só uma noite, para não dirigir de volta a sua cidade depois de passear durante o dia.

No longo prazo, tem-se a proposição da construção de uma estrutura para captação de mais eventos, divulgação do artesanato local além da mudança do CAT, para um local centralizado, por onde os turistas possam passar, parar e se informar mais facilmente.

Para que todo o citado acima possa acontecer, antes de tudo, deve-se pensar na criação de cursos para qualificação e capacitação da mão-de-obra local, para maior satisfação e fidelização do cliente (turista). 
A promoção e divulgação do município é um fator muito importante, com pontos de distribuição bem integrados, preços atraentes, um slogan bem elaborado e conservação e manutenção dos produtos, não tem como não satisfazer a grande maioria dos visitantes.

Por fim, pode-se dizer que o potencial turístico da região só poderá ser bem desenvolvido se todas as providencias sugeridas neste trabalho forem implementadas. Além disto, medidas de qualificação e capacitação deverão ser tomadas resultando em atrativos e estabelecimentos totalmente apropriados para a chegada do cliente em questão, que é o turista. 


\section{VIII - REFERÊNCIAS}

\section{1 - Bibliográficas}

ANSARAH, Marilia Gomes dos Reis. Turismo, Como Aprender, Como ensinar. $2^{\mathrm{a}}$ ed. São Paulo: editora SENAC, 2001.

BENI, Mario Carlos. Análise Estrutural do Turismo. São Paulo: SENAC, 1998.

Paulo: SENAC, 2001.

BOULLÓN, Roberto C. Planejamento do Espaço Turístico. Traduzido por Joely Vianna Baptista. Bauru, SP: EDUSC, 2002.

BRASIL, MINISTÉRIO DO TURISMO, $\mathbf{1 1}^{\circ}$ Relatório de Atividades do Ministério do Turismo, mar/2006.

BURSZTYN, Marcel. A Difícil Sustentabilidade: Política Enérgica e Conflitos Ambientais. Rio de Janeiro, Garamond, 2001.

DE ROSE, Alexandre Turatti. Turismo Planejamento e Marketing. 1 ed Barueri: Manole, 2002.

DENCKER, Ada. F. Métodos e técnicas de pesquisa em turismo. São Paulo: Futura, 1998.

FORMOSA, Guia Turístico de Cultura, Lazer \& Serviços. Alquimia Publicidade, 2003.

GIL, Antônio Carlos. Métodos e técnicas de pesquisa social. São Paulo: Atlas, 2007.

GOVERNO DO ESTADO DO AMAPÁ, Base do Desenvolvimento Sustentável. Coletânea de Textos, 1999.

IBGE, Conta Satélite de Turismo. Publicação da OMT. Dezembro, 2005.

KINKER, Sonia. Ecoturismo e conservação da natureza em parques nacionais. Campinas: Papirus, 2002.

LAGE, Beatriz Helena Gelas; MILONE, Paulo César. Economia do Turismo. 7 ed. rev. e ampl. São Paulo: Atlas, 2001.

MOLINA, Sergio; RODRÍGUEZ, Sergio. Turismo Planejamento Integral. São Paulo: EDUSC, 2001.

ORGANIZAÇÃO MUNDIAL DO TURISMO. Desenvolvimento Sustentável do Turismo. Porto Alegre. Bookman, 2003.

ORGANIZAÇÃO MUNDIAL DO TURISMO. Guia de Desenvolvimento do Turismo Sustentável. Traduzido por Sandra Netz - Porto Alegre: Brookmam, 2003.

PETROCCHI, Mario. Turismo: Planejamento e Gestão. São Paulo: Futura, 1998.

RUIZ, J. A. Metodologia Científica: Guia para a Eficiência nos Estudos. 3 ed. São Paulo: Atlas, 1991.

RUSCHMANN, Doris van de Meene. Turismo e Planejamento Sustentável: A proteção do meio ambiente. Campinas. Papirus, 1997. 
SACHS, Igancy. Desenvolvimento: Includente, Sustentável e Sustentado, Rio de Janeiro, Garamond, 2004.

SACHS, Igancy. Caminhos para o Desenvolvimento Sustentável / org por: Paula Yone Strosh, Rio de Janeiro, Garamond, 2000.

SANCHO, Amparo. Introdução ao turismo - Organização Mundial do Turismo. Traduzido por Dolores Marit Rodrigues Córner. SP: Roca, 2001.

SWARBROOKE, Jonh. Turismo Sustentável: Turismo Cultural, Ecoturismo e Ética. São Paulo. Aleph, 2000.

SWARBROOKE, John; HONER, Susan. O Comportamento do Consumidor no Turismo. Ed Aleph; São Paulo, 2002.

VALLS, Josep-Francesc. Gestão Integral de Destinos Turísticos Sustentáveis/ Josep-Francesc Valls; traduzido por Cristiano Vasques e Liana Wang. Rio de Janeiro; FGV, 2006.

VERGARA. S.C. Projetos e relatórios de pesquisa em administração. São Paulo: Atlas , 2007.

WRIGHT, Peter; KROLL, Mark; PARNELL, John. Planejamento Estratégico Estudos de Caso I. São Paulo, Atlas, 2001.

ZARDO, Eduardo Flávio. Marketing Aplicado ao Turismo: Ferramentas de marketing para empresas de turismo e destinos turísticos. São Paulo; Roca, 2003.

\section{2 - Eletrônicas}

BRASIL, MINISTERIO DO TURISMO. Manual de Regionalização. Disponível em: http://institucinal.turismo.gov.br/regionalizacao/do modulo6.asp. Acesso em: 28.nov.2007

BRASIL, MINISTÉRIO DO TURISMO. Programa Nacional do Turismo. Disponível em:

http://institucional.turismo.gov.br/portalmtur/export/sites/default/Portal_Mtur/geral/Relacao 65 destinos $16 \quad 082007$ sem_Regioes-PARA_DIVULGACAO.doc. Acesso em: 23.mar.2008

INSTITUTO ECOBRASIL. Disponível em: http://www.ecobrasil.org.br/publique/cgi/cgilua.exe/sys/start.htm?tpl=home. Acesso em 13.nov.2007

SECRETARIA DE PlaneJAMENTO DO GOIÁS, Plano Diretor do Município de Formosa, Disponível em: http://www.seplan.go.gov.br/download/planodiretor/PD Formosa.pdf. Acesso em 20.dez.2007.

PORTAL CENTRO OESTE, disponível em: http://www.centroeste.com.br/culinaria/culinaria.htm. Acesso em: 18.jan.2008 


\section{IX - APÊNDICES}

\section{A - Pesquisas com Proprietários dos Atrativos}

Itiquira

1- Você teria o interesse em aumentar o número de visitantes em seu atrativo/estabelecimento?
(x) $\operatorname{Sim}$
( ) Não

1a - Se sua resposta for não, porque?

( ) Está satisfeito

( ) Não tem estrutura para que isso aconteça

( ) Não tem recursos

( ) Não existe incentivos

( ) Outros.Qual?

2 - Seu atrativo/estabelecimento segue normas sustentáveis de desenvolvimento?

(x) $\operatorname{Sim}$

2a - Se sua resposta for sim, Quais?

( ) Coleta seletiva

( ) Economia de água

( ) Economia de luz

(x) Ações de conservação do meio ambiente

( ) Plantil de árvores

( ) Campanhas de conscientização

( ) Outros. Quais?

3 - Quantos empregados você tem?

São no total 35 funcionários

4 - Quantos são da região?

Todos são da região

5 - Qual o nível de escolaridade dos seus funcionários?

Com os mais diversos níveis de escolaridade, por conta da grande diversidade de tarefas no empreendimento.

6 - Se houvessem cursos de capacitação e de qualificação, oferecidos pelo governo, ou mesmo por empresas privadas, você ofereceria aos seus funcionários?
(x) $\operatorname{Sim}$
( ) Não 
Hotel Fazenda Araras

1- Você teria o interesse em aumentar o número de visitantes em seu atrativo/estabelecimento?
(x) $\operatorname{Sim}$
( ) Não

1a - Se sua resposta for não, porque?

( ) Está satisfeito

( ) Não tem estrutura para que isso aconteça

( ) Não tem recursos

( ) Não existe incentivos

( ) Outros.Qual?

2 - Seu atrativo/estabelecimento segue normas sustentáveis de desenvolvimento?

(x) $\operatorname{Sim}$

( ) Não

$2 a$ - Se sua resposta for sim, Quais?

(x) Coleta seletiva

(x) Economia de água

(x) Economia de luz

(x) Ações de conservação do meio ambiente

( ) Plantil de árvores

(x) Campanhas de conscientização

( ) Outros. Quais?

3 - Quantos empregados você tem?

São no total 33 funcionários

4 - Quantos são da região?

22 são da região

5 - Qual o nível de escolaridade dos seus funcionários?

Todos com baixo nível de escolaridade. A maioria tem apenas o primário.

6 - Se houvessem cursos de capacitação e de qualificação, oferecidos pelo governo, ou mesmo por empresas privadas, você ofereceria aos seus funcionários? (x) $\operatorname{Sim}$

( ) Não 


\section{B - Modelo da Pesquisa com os Representantes da Comunidade}

1 - Você acha que o Turismo traz recursos para a Comunidade? Porque?

( ) $\mathrm{Sim}$

( ) Não

Porque?

2 - Você acha que o município tem potencial para ter o Turismo como uma atividade que possa trazer benefícios tanto para a sociedade e também para os empresários?

( ) $\mathrm{Sim}$

( ) Não

3 - Para você qual desses fatores impede que o Turismo se desenvolva no Município?

( ) Infra-estrutura básica e turística desatualizada

( ) Governo local desinteressado

( ) Proprietários desinformados

( ) Falta de Incentivos

( ) Falta de divulgação dos atrativos locais

( ) Comunidade

4 - Você daria incentivo para o desenvolvimento do Turismo sustentável no Município? Por quê?
( ) $\operatorname{Sim}$
( ) Não
Por quê?

5 - Para você o que é Turismo sustentável: 
6 - Quais desses atrativos naturais você conhece?

( ) Salto do Itiquira

( ) Cachoeiras do Indaiá

( ) Buraco das Araras

( ) Gruta das Andorinhas

( ) Cachoeira da Capetinga

( ) Cachoeiras do Bandeirinha

( ) Lajedo

( ) Pedreira Toca da Onça

( ) Sítios Arqueológicos

( ) Mata da Bica

( ) Lagoa Feia

( ) Lago do Vovô

( ) Berço das Águas do Brasil

( ) Trilha do Sino

7 - O que você vê como atrativo cultural da localidade?

8 - O que você acharia do aumento do número de turistas na cidade?
( ) Ótimo
( ) Bom
( ) Regular
( ) Ruim
( ) Não Sei
Porque? 


\section{C - Resultados}

Pesquisa com Representantes do Governo local

1 - Você acha que o Turismo traz recursos para a Comunidade? Por quê?

( ) Sim \begin{tabular}{llllll|l|l|l|}
1 & 2 & 3 & 4 & 5 & 6 & Total & Porcentagem \\
\hline
\end{tabular} \begin{tabular}{|r|r|r|r|r|r|r|r|}
$\mathbf{x}$ & $\mathbf{x}$ & $\mathbf{x}$ & $\mathrm{x}$ & $\mathrm{x}$ & $\mathrm{x}$ & 6 & $100 \%$ \\
\hline & & & & & & 0 & $0 \%$ \\
\hline
\end{tabular}

2 - Você acha que o município tem potencial para ter o Turismo como uma atividade que possa trazer benefícios tanto para a sociedade e também para os empresários?

\begin{tabular}{l} 
( ) Sim \\
\hline ( ) Não
\end{tabular} \begin{tabular}{llllll|l}
1 & 2 & 3 & 4 & 5 & 6 & Total
\end{tabular}

3 - Para você qual desses fatores impede que o Turismo se desenvolva no Município?

( ) Infra-estrutura básica e turística desatualizada ( ) Governo local desinteressado

( ) Proprietários desinformados

( ) Falta de Incentivos

( ) Falta de divulgação dos atrativos locais \begin{tabular}{l|l|l|l|l|l|l}
$\mathrm{x}$ & $\mathrm{x}$ & $\mathrm{x}$ & $\mathrm{X}$ & $\mathrm{x}$ & $\mathrm{x}$ & 6 \\
\hline
\end{tabular} $100 \%$ 6

( ) Falta de Interesse Comunidade $\begin{array}{llllllll}1 & 2 & 3 & 4 & 5 & 6 & \text { Total }\end{array}$

4 - Você incentivaria o Turismo? Se sim, como?

( ) Sim

( ) Não

6 - Quais desses atrativos naturais você conhece?

( ) Salto do Itiquira

( ) Cachoeiras do Indaiá

( ) Buraco das Araras

( ) Gruta das Andorinhas

( ) Cachoeira da Capetinga

( ) Cachoeiras do Bandeirinha

( ) Lajedo

( ) Pedreira Toca da Onça

( ) Sítios Arqueológicos

( ) Mata da Bica

( ) Lagoa Feia

( ) Lago do Vovô

( ) Trilha do Sino

\begin{tabular}{|c|c|c|c|c|c|c|c|}
\hline & & $x$ & $x$ & $x$ & & 3 & $50 \%$ \\
\hline & $x$ & & & & & 1 & $16,70 \%$ \\
\hline & & & $\mathrm{X}$ & & & 1 & $16,70 \%$ \\
\hline $\mathrm{X}$ & $\mathrm{X}$ & & & $x$ & & 3 & $50 \%$ \\
\hline $\mathrm{x}$ & $\mathrm{x}$ & $\mathrm{X}$ & & $\mathrm{x}$ & $x$ & 5 & $83,30 \%$ \\
\hline & & & & & & 0 & $0 \%$ \\
\hline
\end{tabular}

8 - 0 que você acharia do aumento do número de turistas na cidade? Por quê?

\begin{tabular}{|l|l|l|l|l|l|l|l|r|}
\hline ( ) Ótimo & $\mathbf{x}$ & $\mathbf{x}$ & $\mathbf{x}$ & $\mathbf{x}$ & $\mathbf{x}$ & $\mathbf{x}$ & 6 & $100 \%$ \\
\hline ( ) Bom & & & & & & & 0 & $0 \%$ \\
\hline ( ) Regular & & & & & & & 0 & $0 \%$ \\
\hline ( ) Ruim Não Sei & & & & & & 0 & $0 \%$ \\
\hline
\end{tabular}


Pesquisa com coordenadores dos programas sociais

1 - Você acha que o Turismo Traz recursos para a Comunidade? Por quê?

( ) Sim

( ) Não

2 - Você acha que o município tem potencial para ter o Turismo como uma atividade que possa trazes benefícios tanto para a sociedade e também para os empresários?

\begin{tabular}{|lllllllllll|l|l|l|}
1 & 2 & 3 & 4 & 5 & 6 & 7 & 8 & 9 & 10 & 11 & Total \\
\hline
\end{tabular}

( ) $\operatorname{Sim}$

( ) Não

3 - Para você qual desses fatores impede que o Turismo se desenvolva no Município?

( ) Infra-estrutura básica e turística desatualizada

( ) Governo local desinteressado

( ) Proprietários desinformados

( ) Falta de Incentivos

( ) Falta de divulgação dos atrativos locais

( ) Falta de Interesse Comunidade

\begin{tabular}{llllllllllllll}
1 & 2 & 3 & 4 & 5 & 6 & 7 & 8 & 9 & 10 & 11 & Total \\
\hline & $x$ & $x$ & $x$ & $x$ & $x$ & $x$ & & $x$ & $x$ & $x$ & 11
\end{tabular}

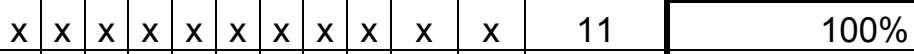

0

$0 \%$

\begin{tabular}{|llllllllllllll}
1 & 2 & 3 & 4 & 5 & 6 & 7 & 8 & 9 & 10 & 11 & Total \\
\hline
\end{tabular}

$x$

\begin{tabular}{|c|c|c|c|c|c|c|c|c|c|c|c|}
\hline & $\mathrm{x}$ & & & $\mathrm{x}$ & $\mathrm{x}$ & $\mathrm{x}$ & & & 4 \\
$\mathrm{x}$ & $\mathrm{x}$ & $\mathrm{x}$ & & & $\mathrm{x}$ & $\mathrm{x}$ & $\mathrm{x}$ & $\mathrm{x}$ & $\mathrm{x}$ & 8 \\
$\mathrm{x}$ & $\mathrm{x}$ & $\mathrm{x}$ & & & $\mathrm{x}$ & $\mathrm{x}$ & $\mathrm{x}$ & $\mathrm{x}$ & & & 7 \\
$\mathrm{x}$ & $\mathrm{x}$ & & $\mathrm{x}$ & & $\mathrm{x}$ & & $\mathrm{x}$ & & $\mathrm{x}$ & $\mathrm{x}$ & 7 \\
\hline
\end{tabular}

$45,40 \%$

$54,50 \%$

$36,40 \%$

$72,70 \%$

$63,60 \%$

$63,60 \%$
4 - Você incentivaria o Turismo? Se sim, como?

\begin{tabular}{|l|c|c|c|c|c|c|c|c|c|c|c|c|}
\hline ( ) $\operatorname{Sim}$ & $\mathrm{x}$ & $\mathrm{x}$ & $\mathrm{x}$ & $\mathrm{x}$ & $\mathrm{x}$ & $\mathrm{x}$ & $\mathrm{x}$ & $\mathrm{x}$ & $\mathrm{x}$ & $\mathrm{x}$ & $\mathrm{x}$ & 11 \\
\hline ( ) Não & & & & & & & & & & & & 0 \\
\hline
\end{tabular}

6 - Quais desses atrativos naturais você conhece?

( ) Salto do Itiquira

( ) Cachoeiras do Indaiá

( ) Buraco das Araras

( ) Gruta das Andorinhas

( ) Cachoeira da Capetinga

( ) Cachoeiras do Bandeirinha

( ) Lajedo

( ) Pedreira Toca da Onça

( ) Sítios Arqueológicos

( ) Mata da Bica

( ) Lagoa Feia

( ) Lago do Vovô

( ) Trilha do Sino

\begin{tabular}{|c|c|c|c|c|cccccc|c|c|}
1 & 2 & 3 & 4 & 5 & 6 & 7 & 8 & 9 & 10 & 11 & Total \\
\hline$x$ & $x$ & $\mathrm{x}$ & $\mathrm{x}$ & $\mathrm{x}$ & $\mathrm{x}$ & $\mathrm{x}$ & $\mathrm{x}$ & $\mathrm{x}$ & $\mathrm{x}$ & $\mathrm{x}$ & & 11 \\
\hline
\end{tabular}

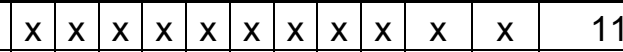

$\mathrm{x}$

$\mathrm{x}$

8 - O que você acharia do aumento do

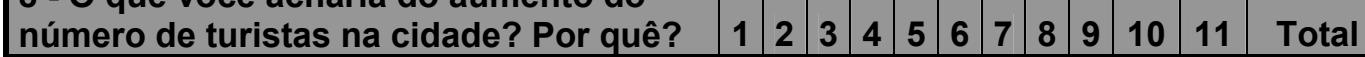

\begin{tabular}{|c|c|c|c|c|c|c|c|c|c|c|c|c|c|}
\hline ( ) Ótimo & & $\mathrm{x}$ & & $\mathrm{x}$ & $x$ & $x$ & & 2 & & & $x$ & 7 & $63,60 \%$ \\
\hline ( ) Bom & $x$ & & $x$ & & & & 2 & & & & & 4 & $36,40 \%$ \\
\hline ( ) Regular & & & & & & & & & & & & 0 & $0 \%$ \\
\hline ( ) Ruim & & & & & & & & & & & & 0 & $0 \%$ \\
\hline ( ) Não Sei & & & & & & & & & & & & 0 & $0 \%$ \\
\hline
\end{tabular}




\section{D - Roteiro para entrevista com os secretários de Desenvolvimento Econômico e de Cultura e Turismo.}

Qual seria o papel do turismo no desenvolvimento econômico da região?

Existe um plano de desenvolvimento do município por meio do turismo?

Se sim, poderiam me informar as linhas gerais desse plano?

No caso desse projeto, existe o intuito de envolver a comunidade local?Se sim, como seria essa relação?

Qual a situação do turismo na região?

Qual a sua opinião a respeito do comportamento do turista na região?

Quem são os responsáveis pelo turismo na região?

Quem é o maior público alvo do município?

Para você, como o turismo pode aumentar as divisas da região?

A prefeitura teria condições e estaria disposta a firmar parcerias para implementação do turismo na localidade?

Na sua opinião, qual a maior dificuldade para implementar um plano de turismo na região?

(Pegar o ponto de vista de cada um)

Se falarem em incentivos, perguntar que tipo de incentivos e por parte de quem!

Diante de tantos atrativos, naturais e culturais, vocês têm idéia de qual seria a posição da sociedade, diante o aumento do fluxo de turistas na região? 


\section{E - Imagens}

Atrativos Naturais

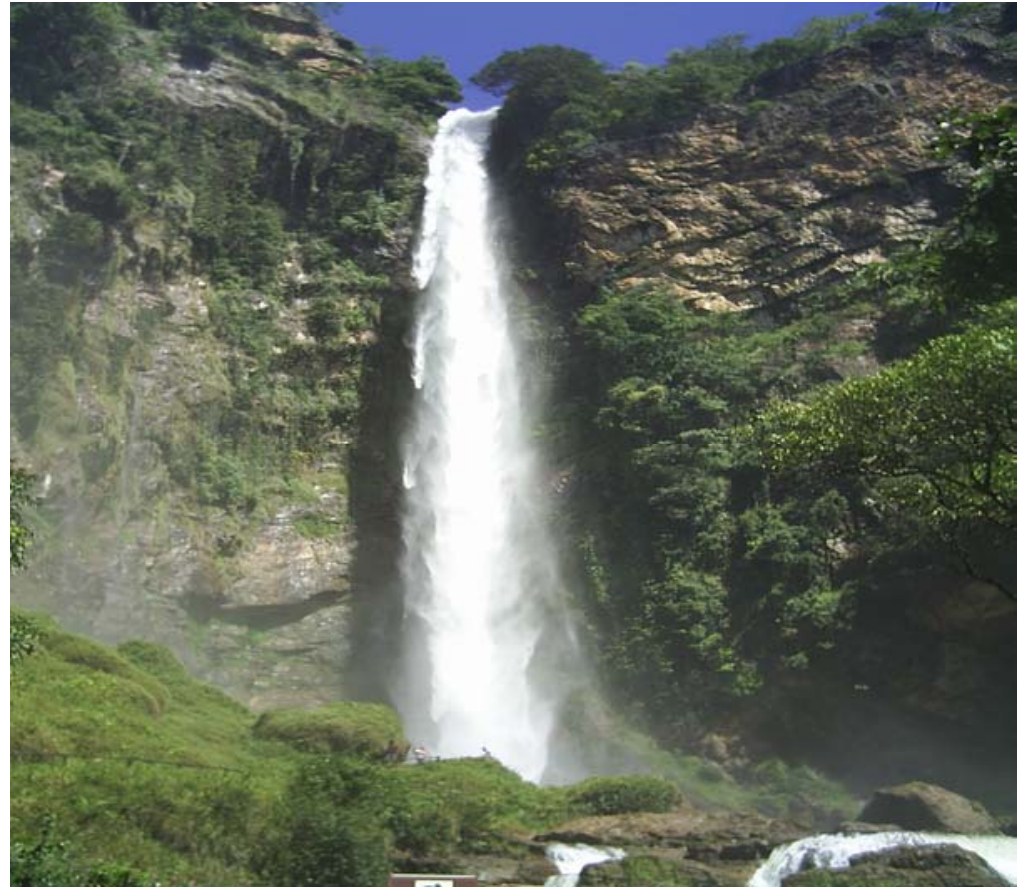

Imagem 1 - Salto do Itiquira

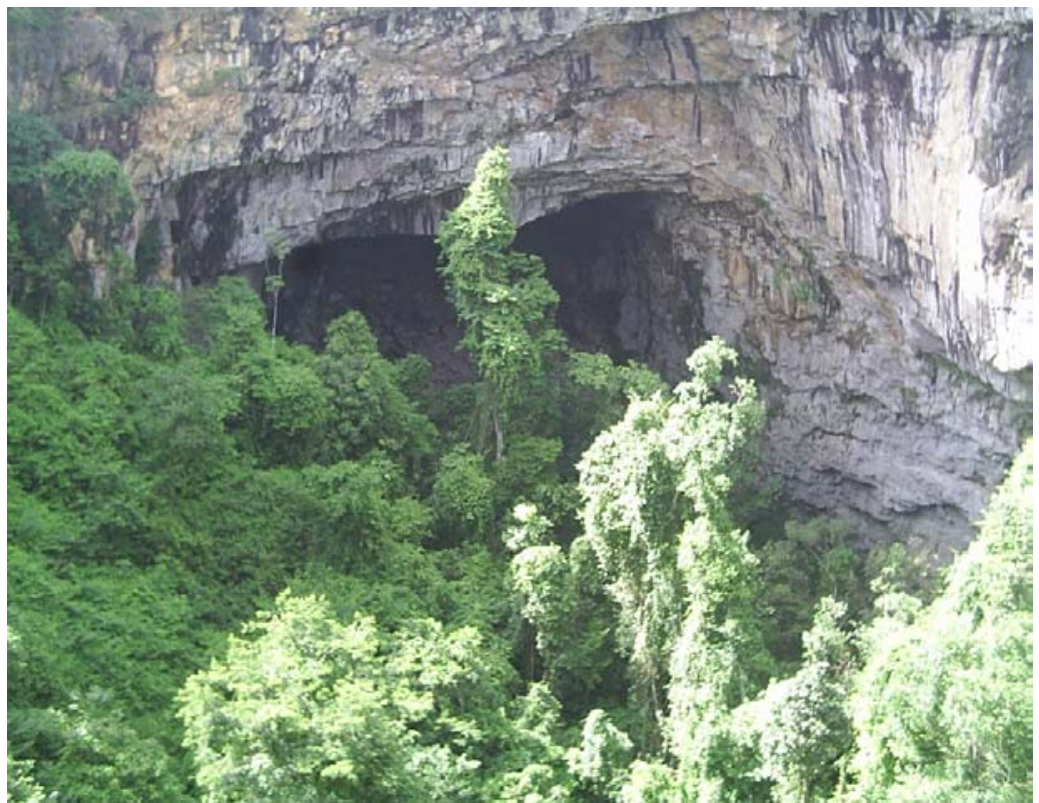

Imagem 2 - Buraco das Araras 


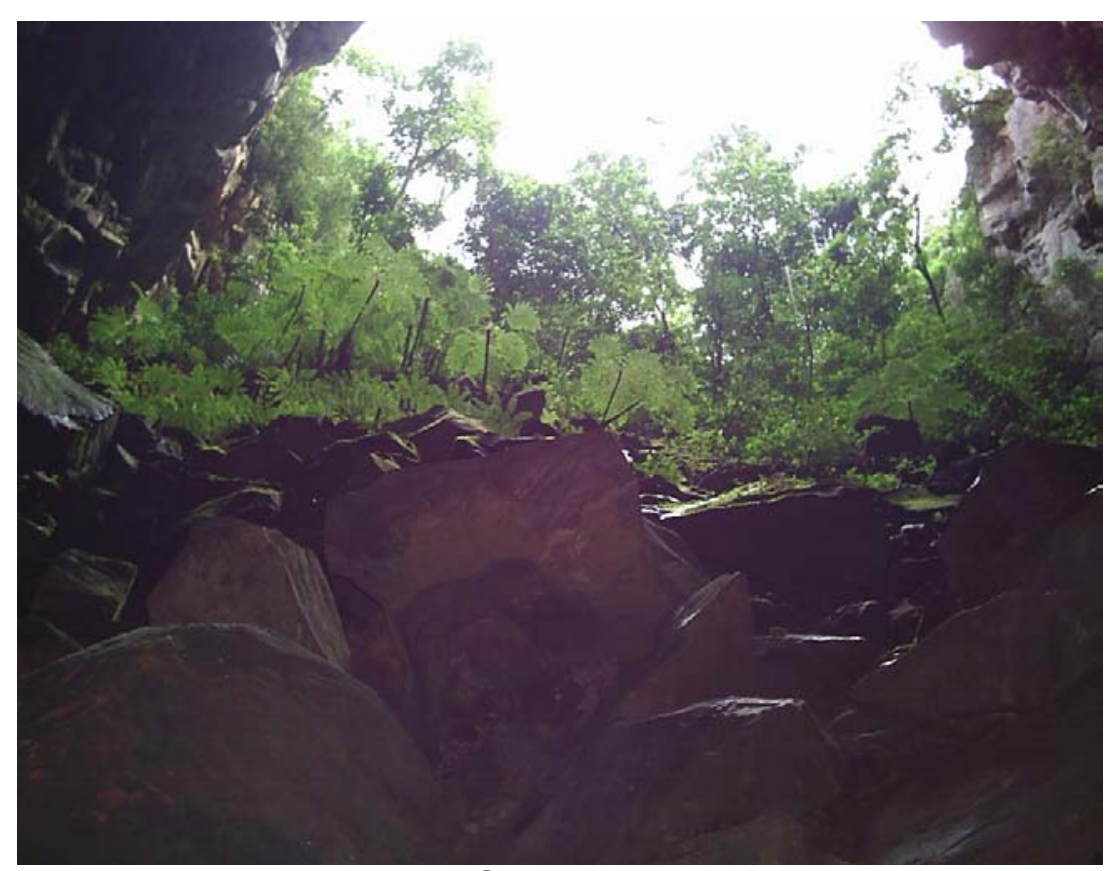

Imagem 3 - Gruta das Andorinhas

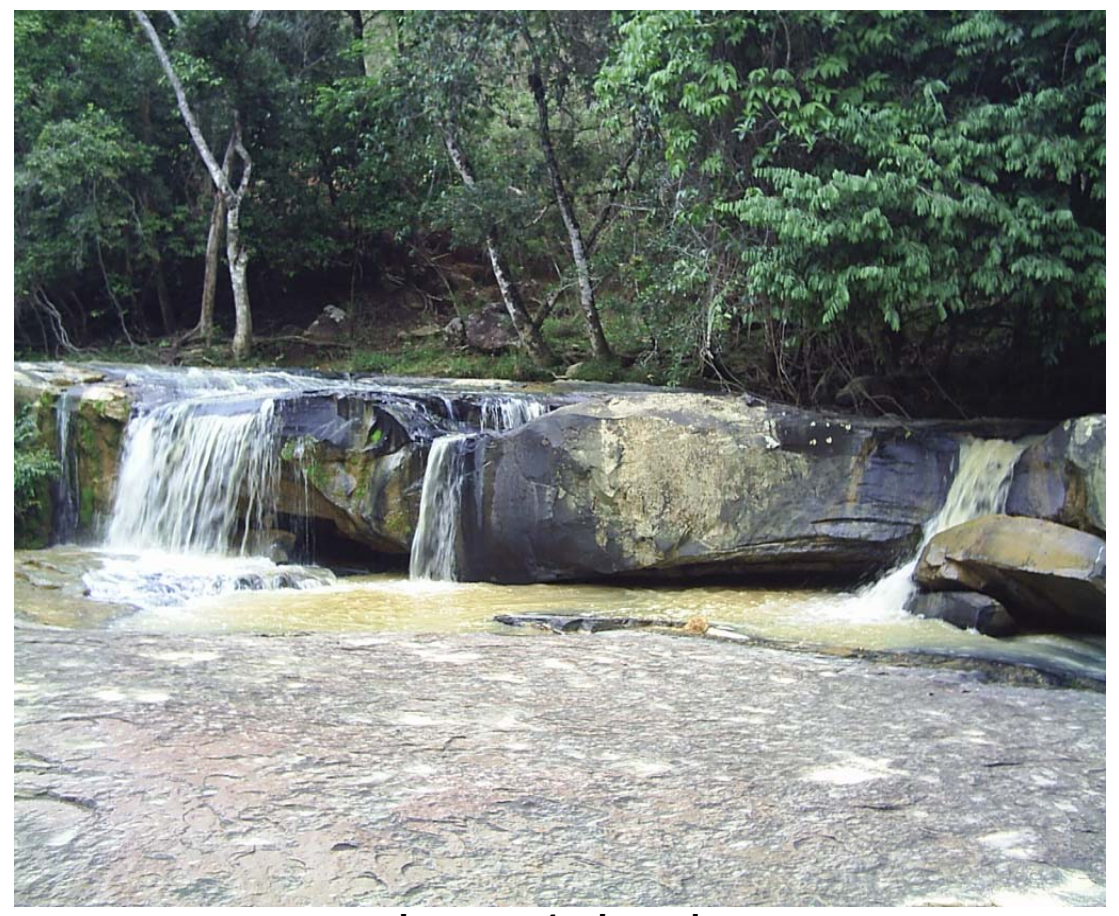

Imagem 4 - Lagedo 


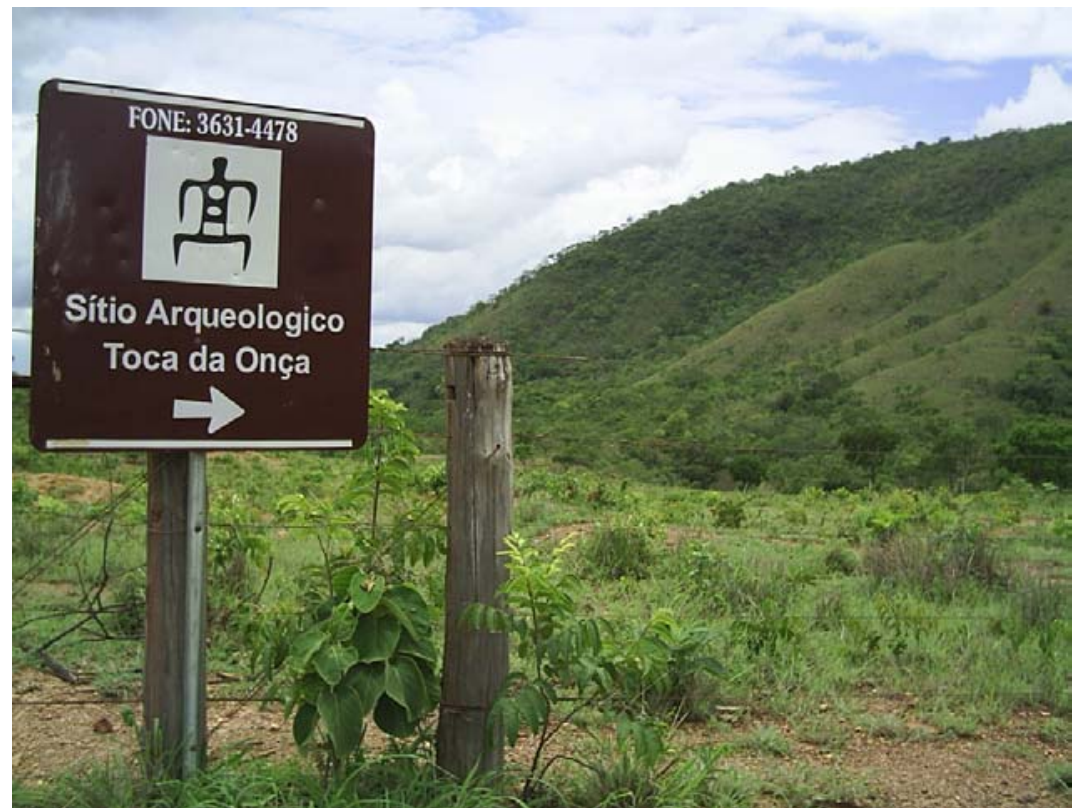

Imagem 5 - Entrada do Sítio Arqueológico Toca da Onça

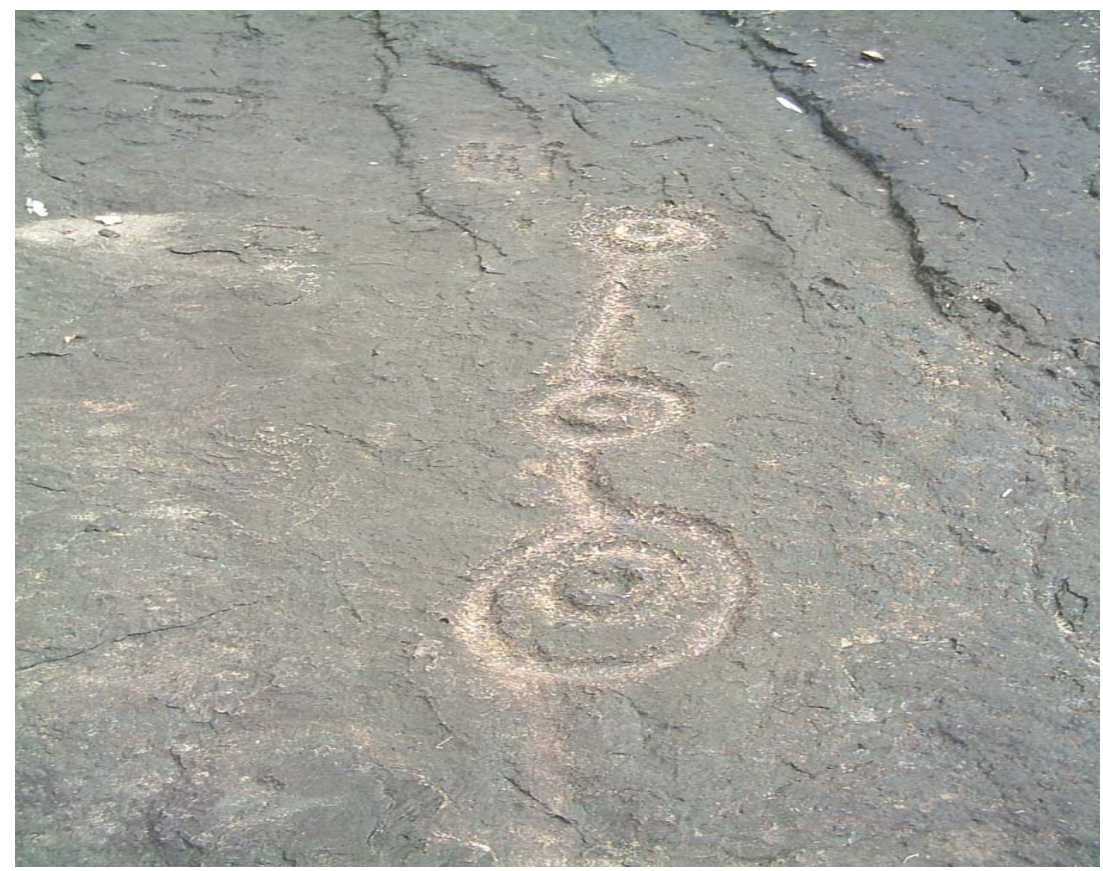

Imagem 6 - Sítio Arqueológico do Bisnau 


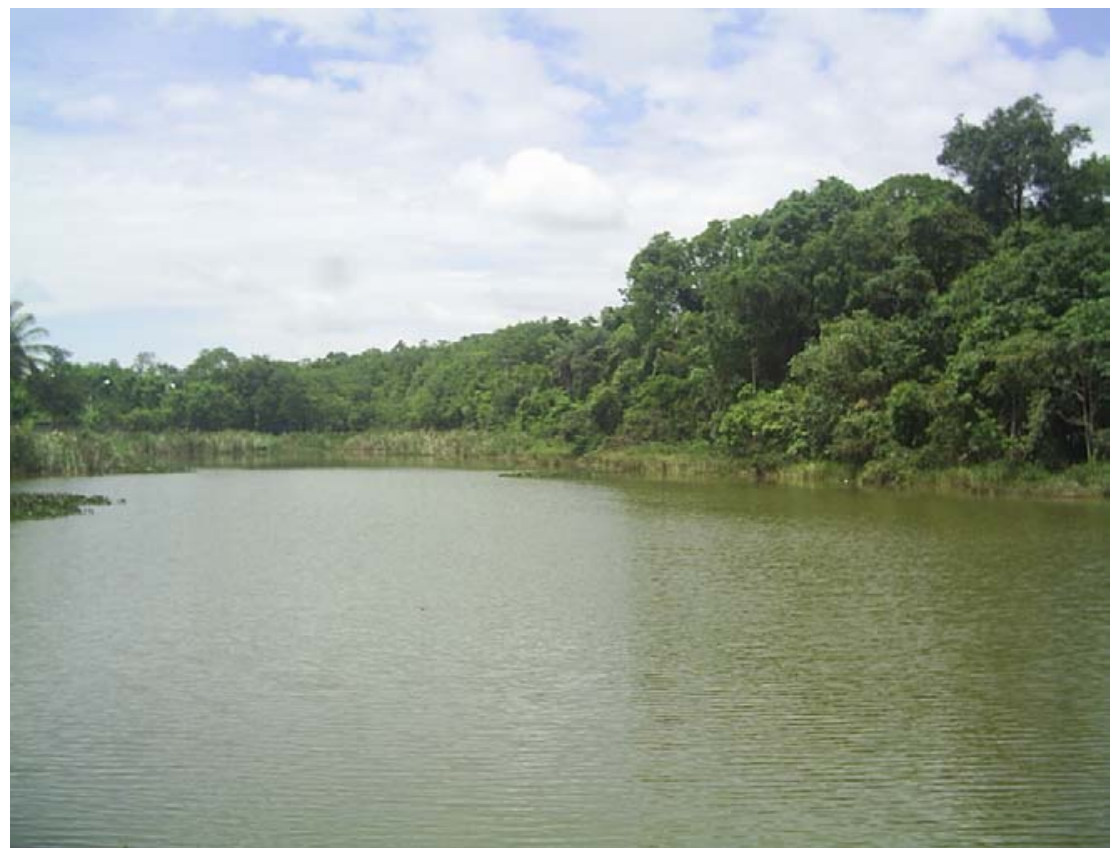

Imagem 7 - Parque Ecológico Mata da Bica

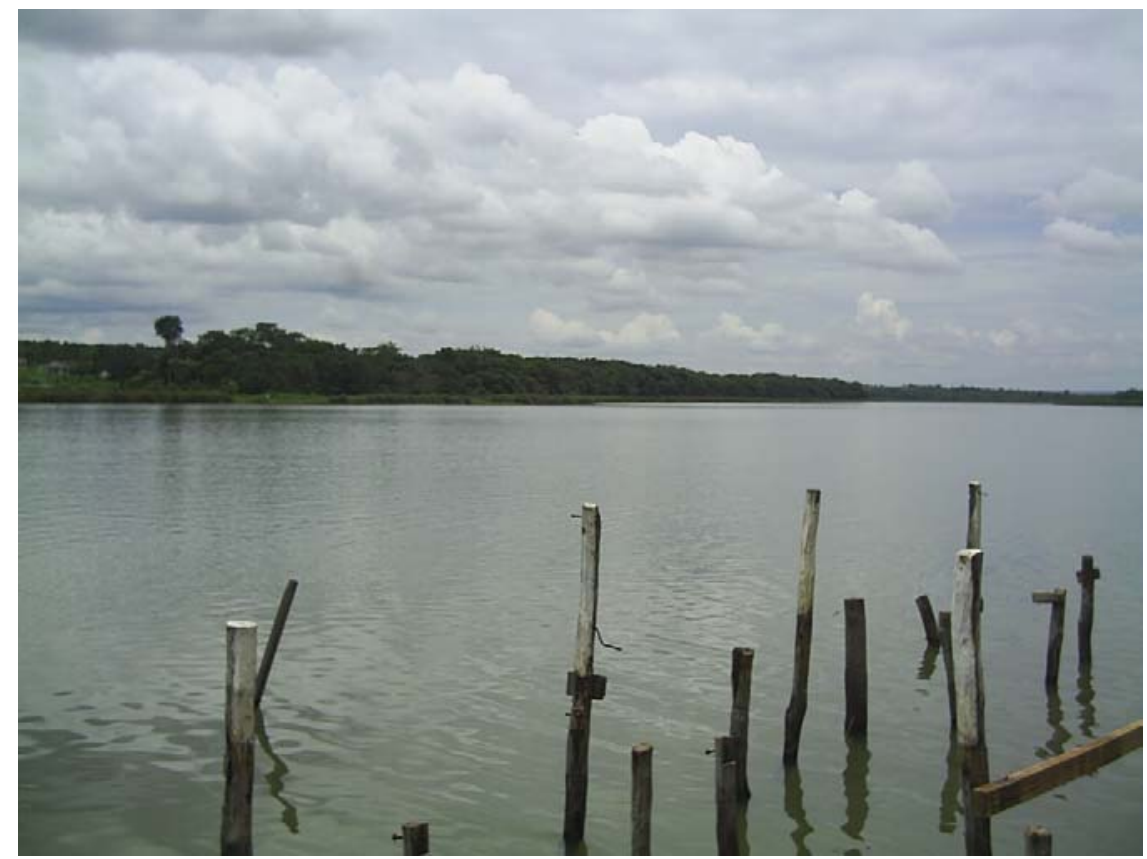

Imagem 8 - Lagoa Feia 


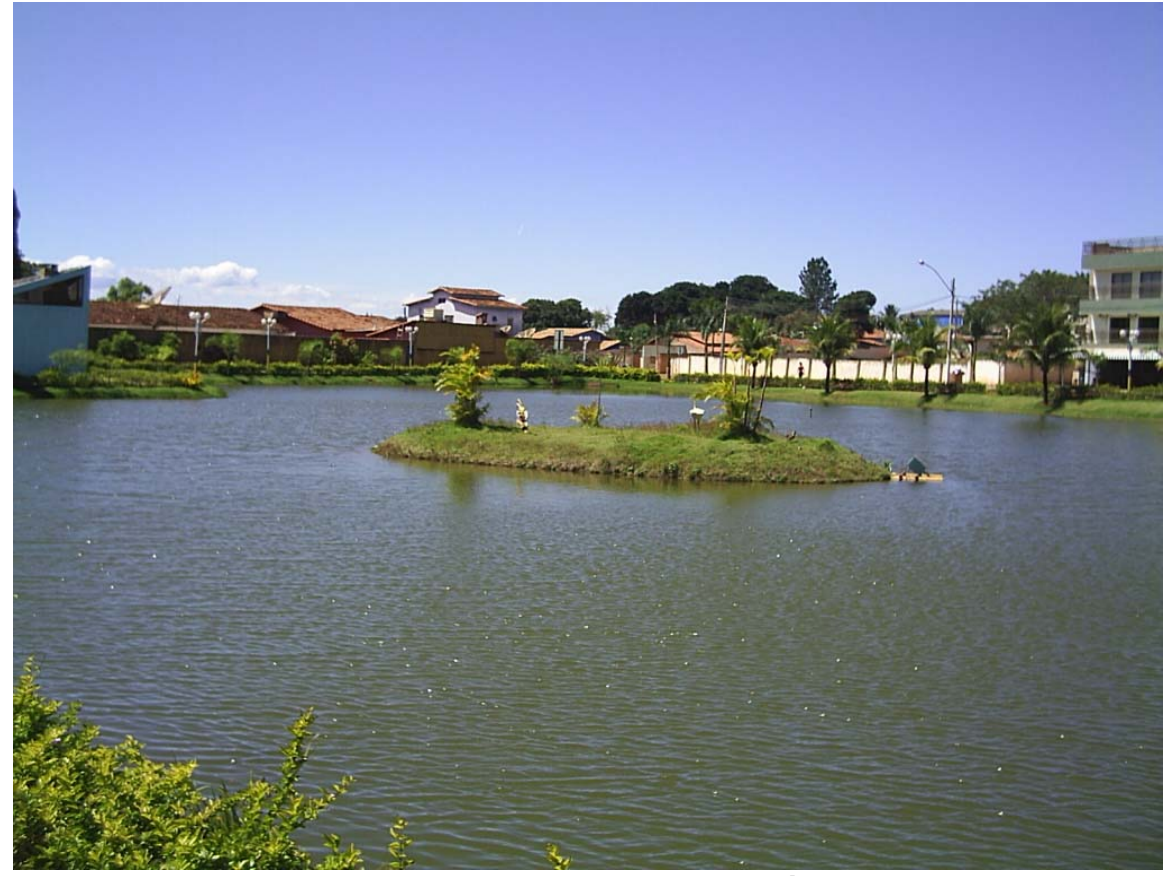

Imagem 9 - Lago do Vovô

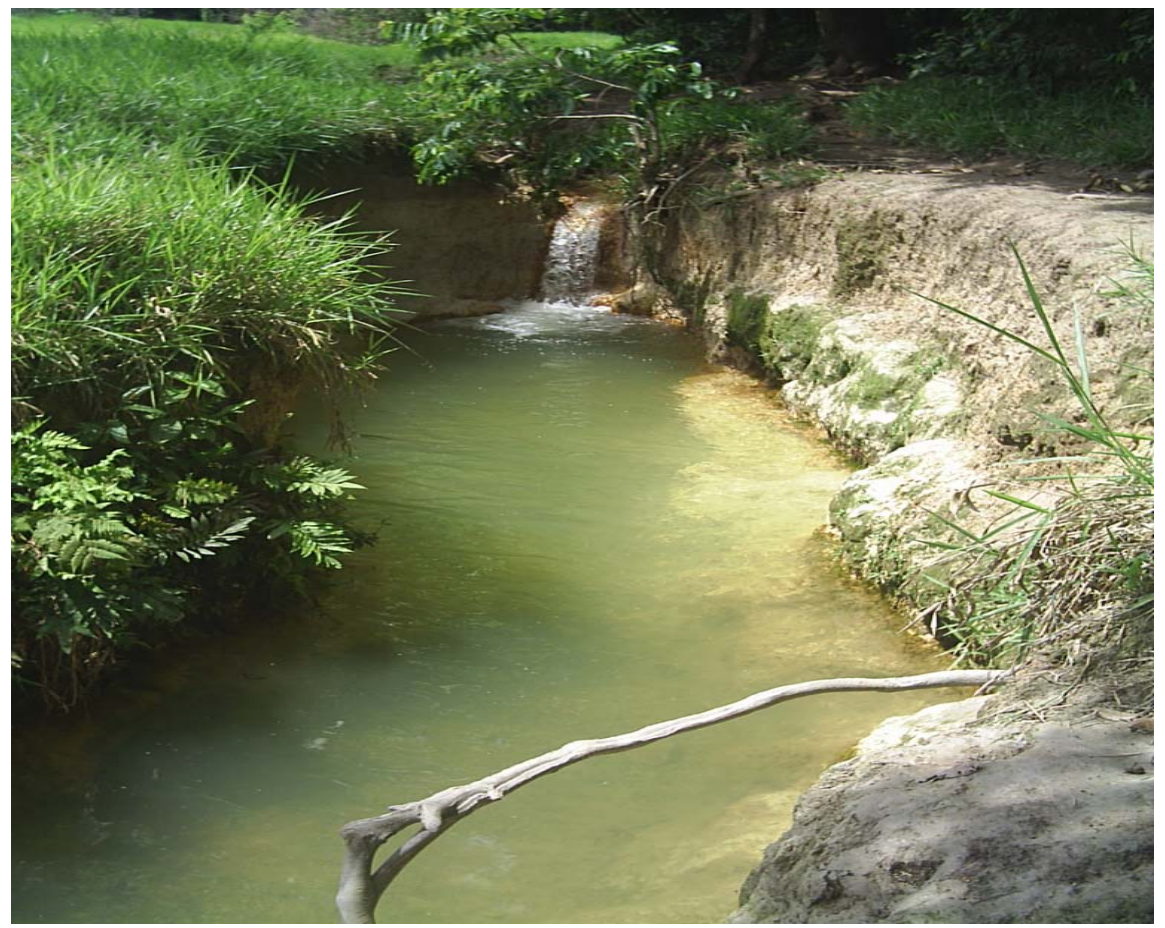

Imagem 10 - Nascente de um dos afluentes da Bacia do São Francisco 
Atrativos Culturais e Infra-Estrutura

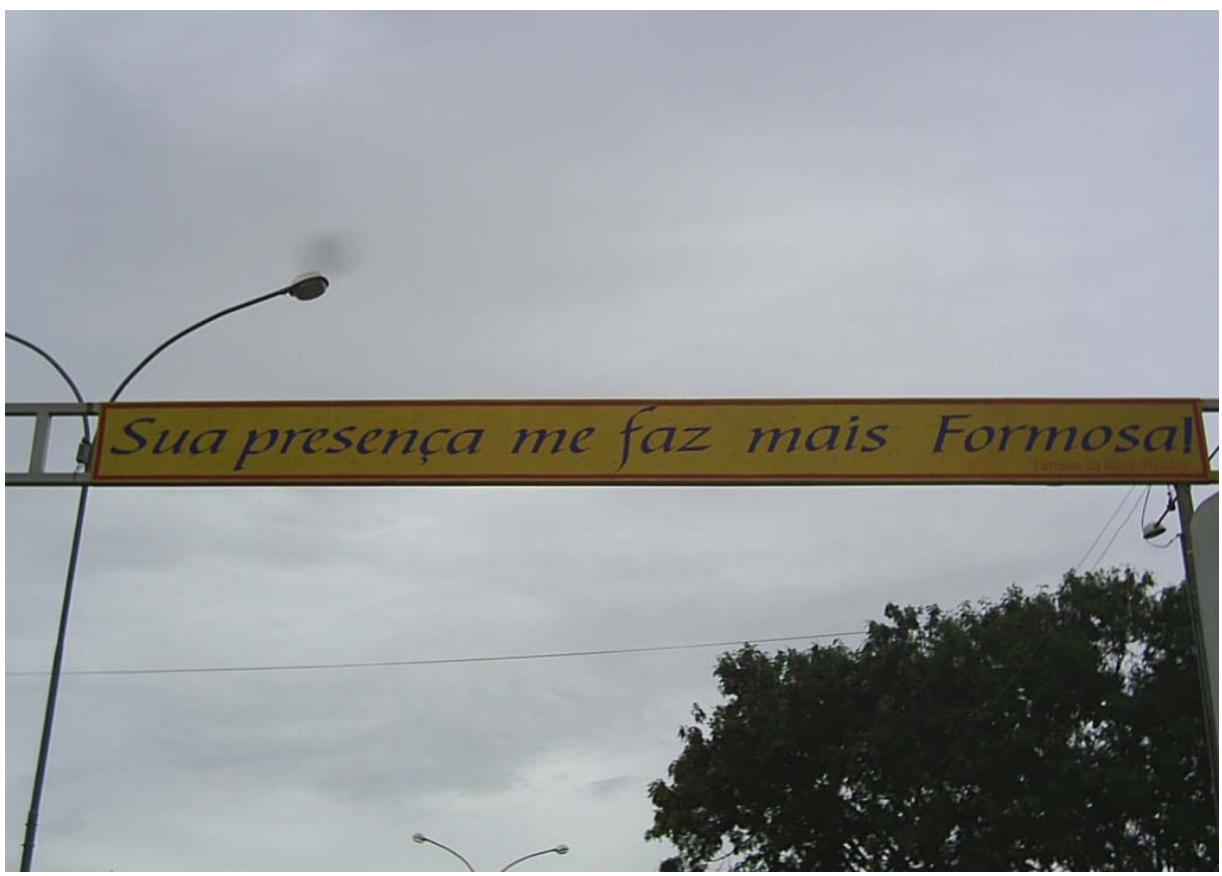

Imagem 11 - Entrada da Cidade

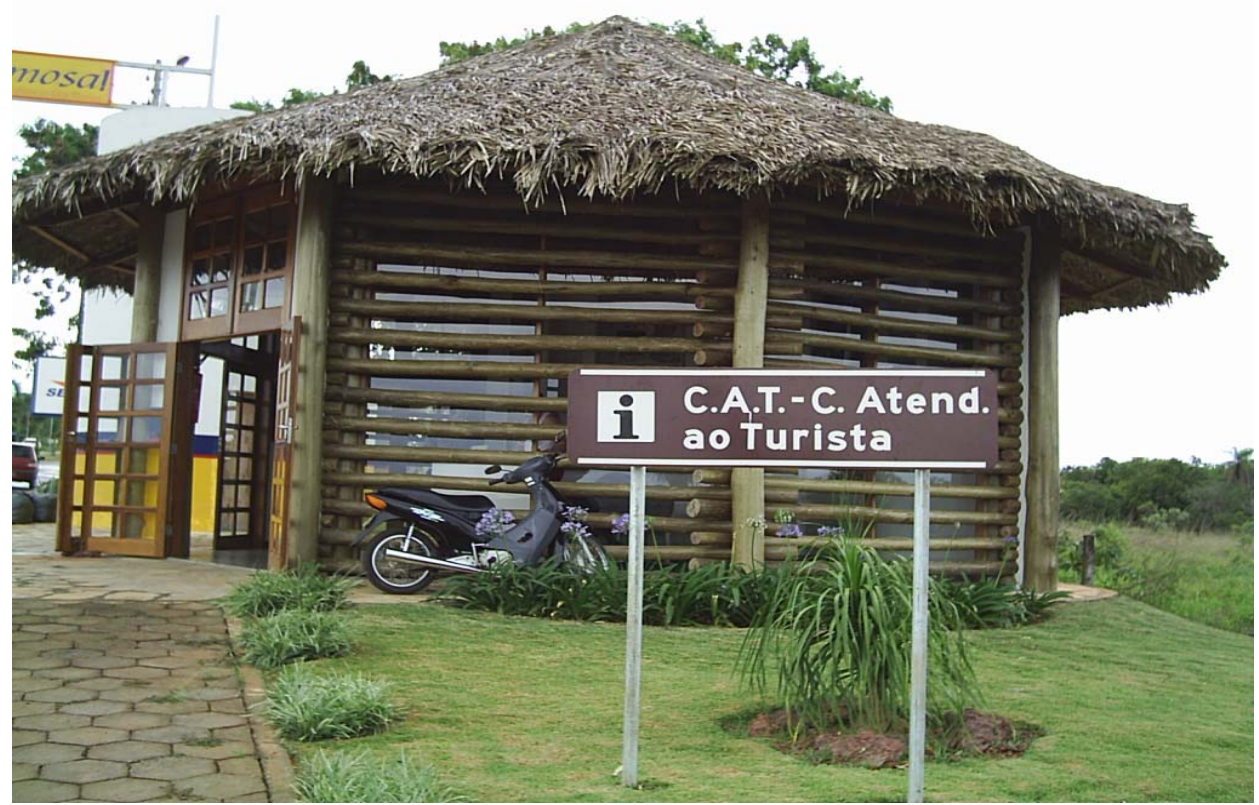

Imagem 12 - Centro de Atendimento ao Turista 


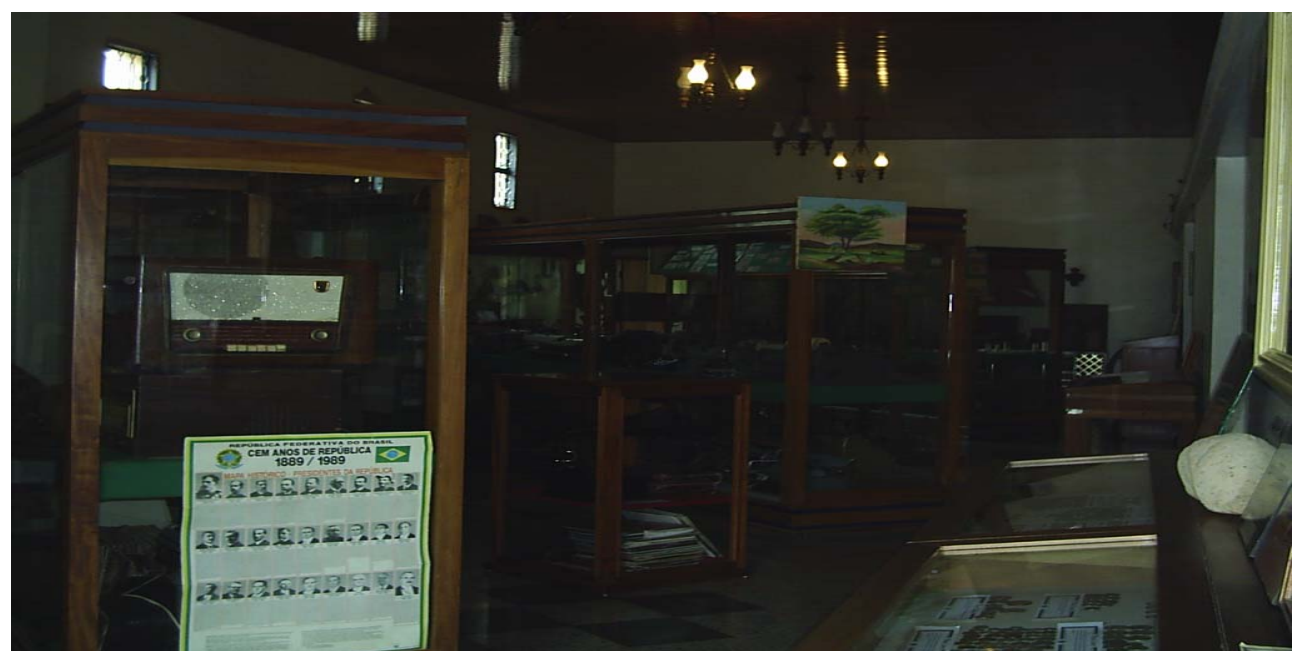

Imagem 13 - Interior do Centro de Cultura Tradição e Turismo de Formosa
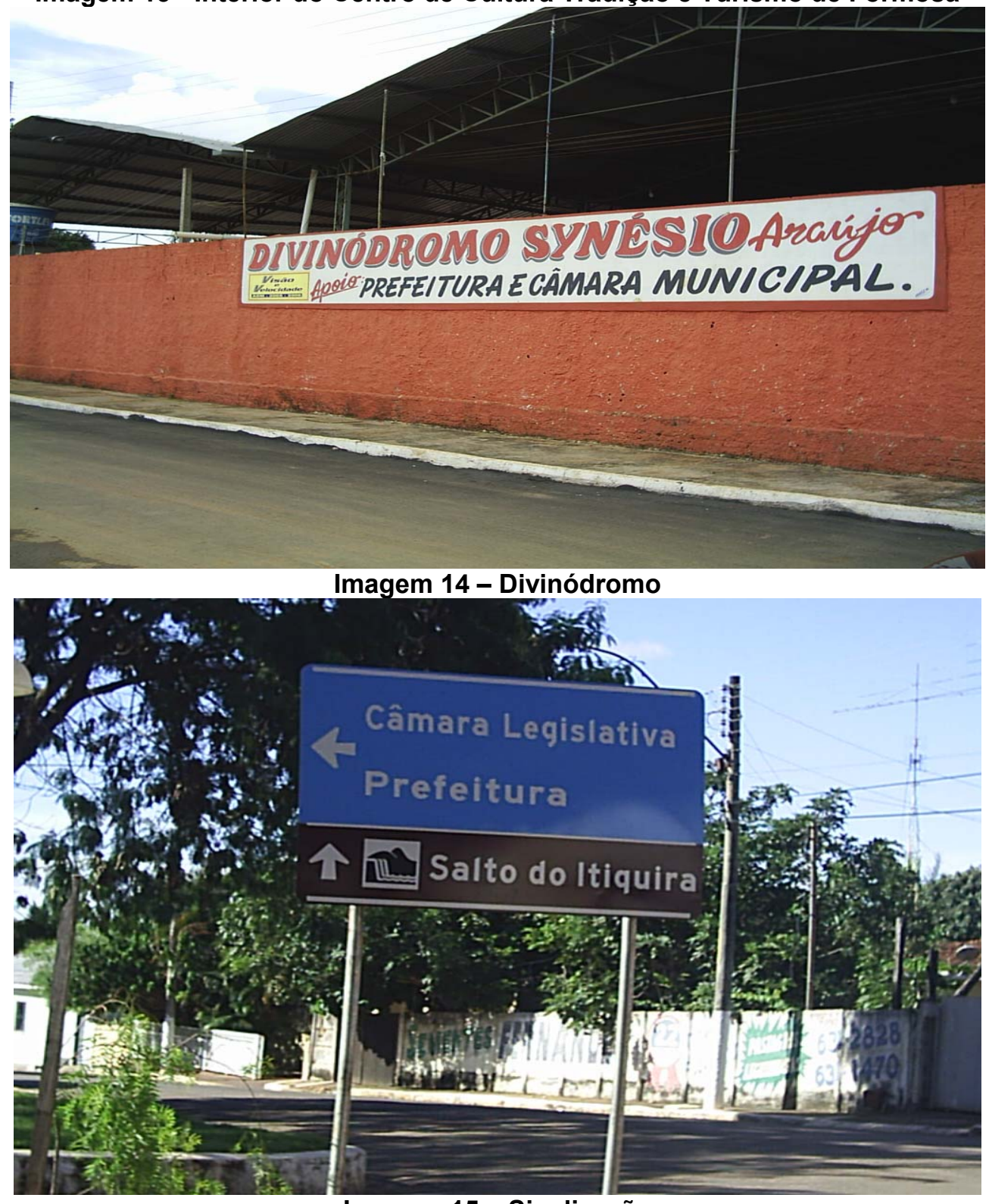

Imagem 15 - Sinalização 